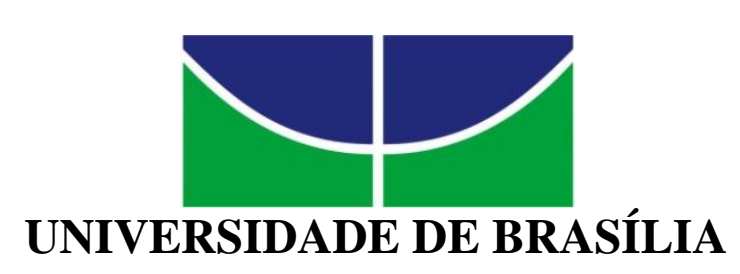

FACULDADE DE AGRONOMIA E MEDICINA VETERINÁRIA PROGRAMA DE PÓS-GRADUAÇÃO EM CIÊNCIAS ANIMAIS

FISIOLOGIA E MANIPULAÇÃO DO CICLO ESTRAL DOS BOVINOS DA RAÇA CURRALEIRO PÉ-DURO

RODRIGO DORNELES TORTORELLA

TESE DE DOUTORADO EM CIÊNCIAS ANIMAIS

BRASÍLIA/DF

OUTUBRO DE 2014 


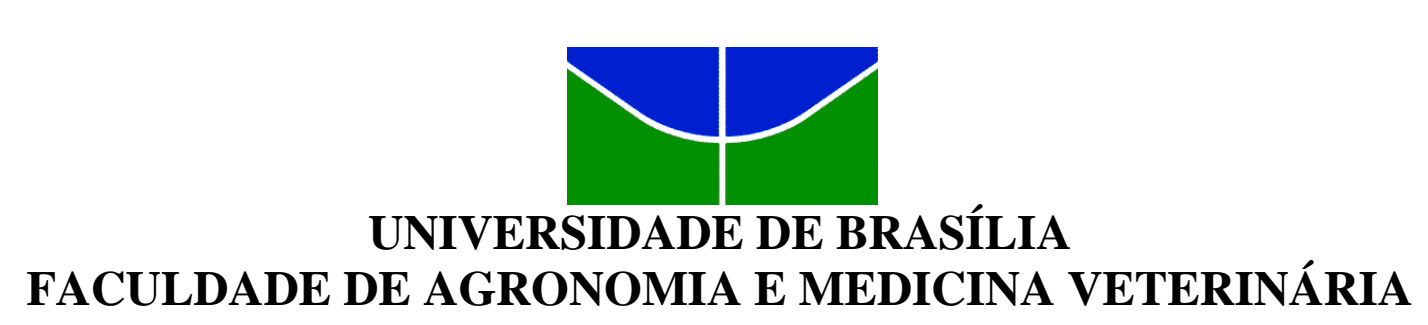

FISIOLOGIA E MANIPULAÇÃO DO CICLO ESTRAL DOS BOVINOS DA RAÇA CURRALEIRO PÉ-DURO

Aluno: Rodrigo Dorneles Tortorella

Orientador: Prof. Dr. Jairo Pereira Neves

Co-orientador: Dr. Alexandre Floriani Ramos

TESE DE DOUTORADO EM CIÊNCIAS ANIMAIS

PUBLICAÇÃ̃: 112D/2014

BRASÍLIA/DF

OUTUBRO DE 2014 


\section{REFERÊNCIA BIBLIOGRÁFICA E CATALOGAÇÃo}

TORTORELLA, R.D. Fisiologia e manipulação do ciclo estral dos bovinos da raça Curraleiro Pé-Duro. Brasília: Faculdade de Agronomia e Medicina Veterinária, Universidade de Brasília, 2014, 102 p. Tese de Doutorado.

Documento formal, autorizando reprodução desta tese de doutorado para empréstimo ou comercialização, exclusivamente para fins acadêmicos, foi passado pelo autor à Universidade de Brasília e acha-se arquivado na Secretaria do Programa. Nenhuma parte desta tese de doutorado pode ser reproduzida sem a autorização por escrito do autor ou do seu orientador. Citações são estimuladas desde que citadas às fontes.

\section{FICHA CATALOGRÁFICA}

TORTORELLA, R.D. Fisiologia e manipulação do ciclo estral dos bovinos da raça Curraleiro Pé-Duro. Brasília: Faculdade de Agronomia e Medicina Veterinária, Universidade de Brasília, 2014, 102 p. Tese (Doutorado em Ciências Animais) - Faculdade de Agronomia e Medicina Veterinária da Universidade de Brasília, 2014.

1. Curraleiro Pé-Duro. 2. Conservação. 3. Dinâmica Folicular. 4. IATF. I. Neves, Jairo Pereira, orientador. II. Ramos, Alexandre Floriani, coorientador. III. Título. 


\section{UNIVERSIDADE DE BRASÍLIA \\ FACULDADE DE AGRONOMIA E MEDICINA VETERINÁRIA}

FISIOLOGIA E MANIPULAÇÃO DO CICLO ESTRAL DO BOVINOS DA RAÇA CURRALEIRO PÉ-DURO

RODRIGO DORNELES TORTORELLA

TESE DE DOUTORADO SUBMETIDA AO PROGRAMA DE PÓS-GRADUAÇÃO EM CIÊNCIAS ANIMAIS COMO PARTE DOS REQUISITOS NECESSÁRIOS À OBTENÇÃO DO GRAU DE DOUTOR EM CIÊNCIAS ANIMAIS.

APROVADA POR:

JAIRO PEREIRA NEVES, Doutor (UnB)

MARIA CLORINDA SOARES FIORAVANTI, Doutora (UFG)

MARILÍA VIVIANE SNEL DE OLIVEIRA, Doutora (UPIS)

IVO PIVATO, Doutor (UnB)

RODRIGO ARRUDA DE OLIVEIRA, Doutor (UnB)

BRASÍLIA/DF, 02 de outubro de 2014. 


\section{DEDICATÓRIA}

Aos meus pais, Ernani Azambuja Tortorella e Silvia Maria Dorneles Borges pela dedicação e trabalho para que eu tivesse essa oportunidade de estudo;

A minha companheira de caminhada Catiuscie Cabreira da Silva e minha filha Marina da Silva Dorneles Tortorella, que são a fonte da minha alegria. 


\section{AGRADECIMENTOS}

Aos meus familiares, especialmente minha avó Rose, Domingas e tia Marta;

Às minhas tias Édna, Helenice e tio Adilson, pelo suporte enquanto residi em Brasília que fez com que eu me sentisse na minha própria casa;

Ao tio Pacheco, tia Bia e Eric que foram incansáveis companheiros e amigos no momento que mais precisei da ajuda de todos;

Aos meus médicos, em especial ao Vitor Sfforni, pela segunda chance de vida que me propiciou;

Ao amigo e orientador Jairo Pereira Neves, que com sua sabedoria fez com que eu seguisse por este caminho. Agradeço-te pelas conversas profissionais e particulares que me fizeram crescer como profissional e ser humano, além do apoio no momento mais difícil de minha vida;

Ao meu co-orientador e amigo Alexandre Floriani Ramos, que foi fundamental para o desenvolvimento do trabalho. Obrigado pela possibilidade de conhecer este novo mundo que é a conservação animal e pela compreensão e ajuda durante toda esta caminhada.

Aos colegas da EMBRAPA, em especial ao Mairon Rocha, Priscilla Passini, Heitor Castro, Japão e Manoel pela ajuda nas atividades do projeto e conversas durante as madrugadas de trabalho;

A Embrapa Recursos Genéticos e Biotecnologia, especialmente aos funcionários do Campo Experimental Sucupira;

Aos amigos Ives Yokota, Carlos Morris, Fernando Martins e Vagner Pedroso que provaram que o amigo não é aquele que vemos todos os dias, mas o que aparece nos momentos mais difíceis;

A CAPES pela bolsa de estudo e ao CNPq pela conseção da bolsa;

Ao CNPq e a FAP-DF pelo apoio financeiro;

Enfim, a todos que contribuíram e torceram por mim. 


\section{ÍNDICE}

Capítulos/Sub-capítulos

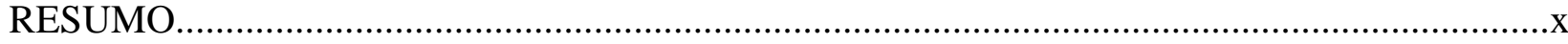

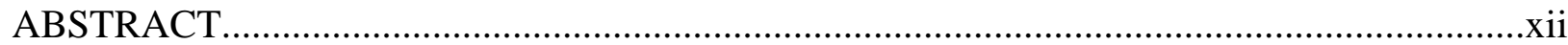

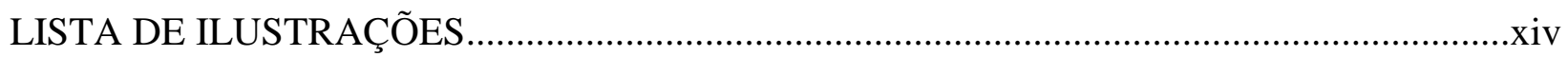

LISTA DE TABELAS.........................................................................................................

LISTA DE SÍMBOLOS E ABREVIAÇÕES............................................................................

CAPÍTULO 1 - INTRODUÇÃO E REVISÃO DE LITERATURA..............................................1

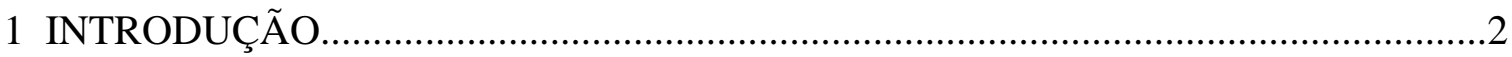

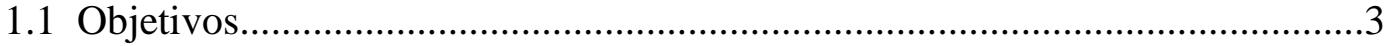

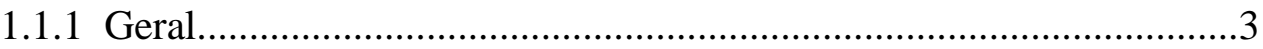

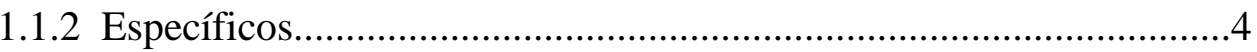

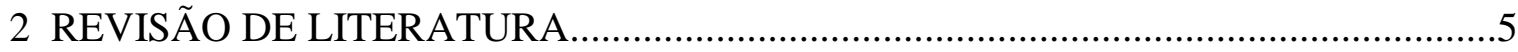

2.1 Origem e Características Raciais do Curraleiro Pé-Duro......................................5

2.2 Conhecimento da Fisiologia Reprodutiva Manejo Genético de Pequenas

Populações.

2.3 A IATF como Técnica Reprodutiva Multiplicadora da Genética do Curraleiro Pé-Duro

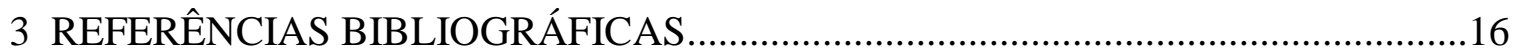

CAPÍTULO 2 - DINÂMICA FOLICULAR OVARIANA DURANTE O CICLO ESTRAL EM VACAS LOCALMENTE ADAPTADAS DA RAÇA CURRALEIRO PÉ-DURO.........28

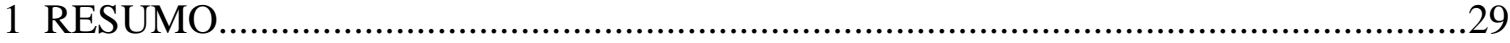

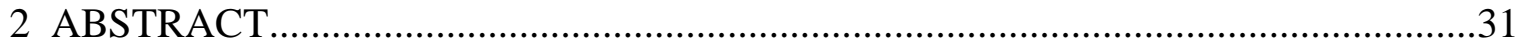

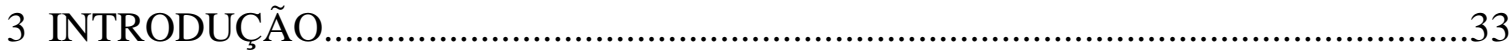

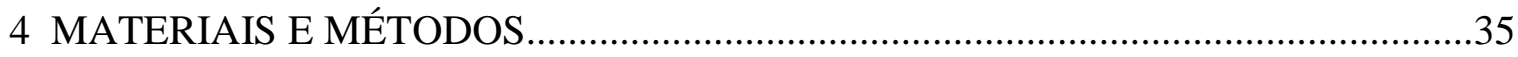

4.1 Local, Manejo Alimentar e Animais...................................................................35

4.2 Sincronização da Ovulação e Avaliação Ultrassonográfica...............................35

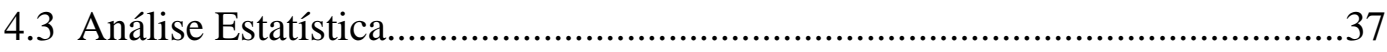

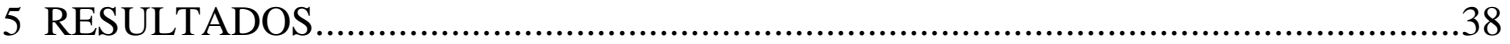

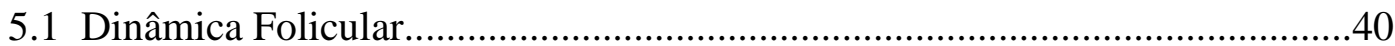


5.2 Volume Luteal $\left(\mathrm{mm}^{3}\right)$. .42

6 DISCUSSÃO .44

7 AGRADECIMENTOS .51

8 REFERÊNCIAS BIBLIOGRÁFICAS. .52

CAPÍTULO 3 - EMERGÊNCIA E DIVERGÊNCIA NA PRIMEIRA ONDA FOLICULAR EM BOVINOS LOCALMENTE ADAPTADOS DA RAÇA CURRALEIRO PÉ-DURO....57

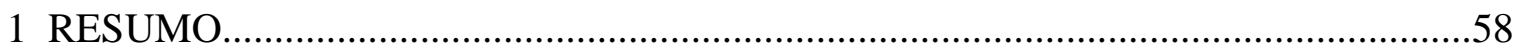

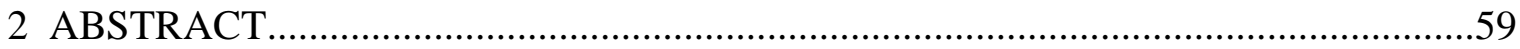

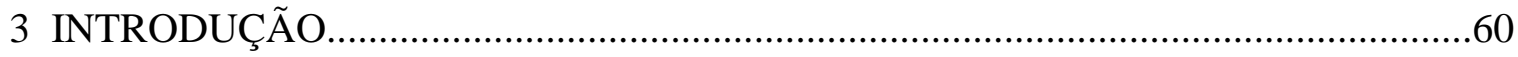

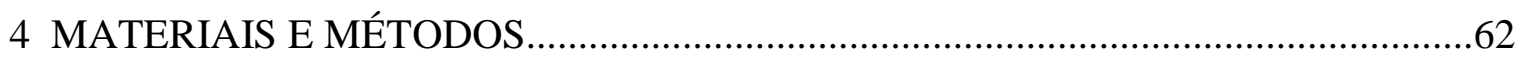

4.1 Local, Manejo Alimentar e Animais..............................................................62

4.2 Sincronização da Ovulação e Avaliação Ultrassonográfica...........................62

4.3 Análise Estatística...........................................................................63

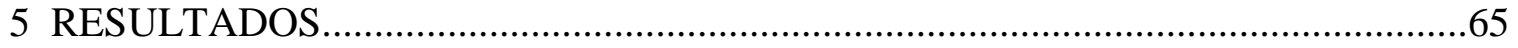

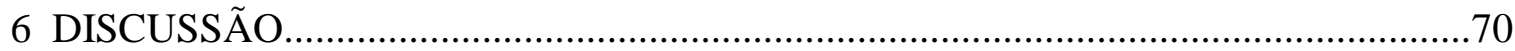

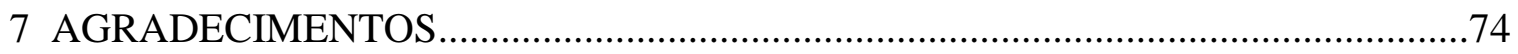

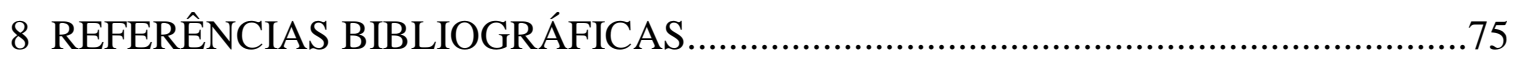

CAPÍTULO 4 - BASES PARA O DESENVOLVIMENTO DE PROTOCOLOS DE INSEMINAÇÃO ARTIFICIAL EM TEMPO FIXO NA RAÇA LOCALMENTE

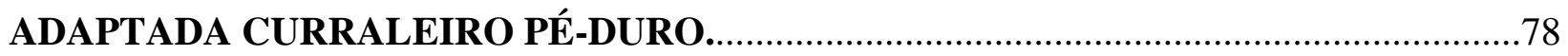

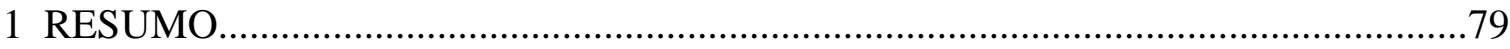

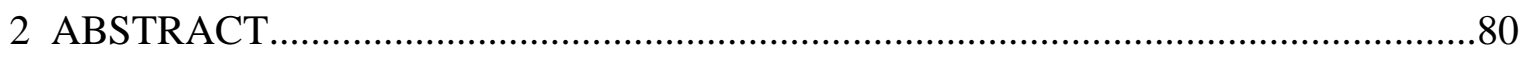

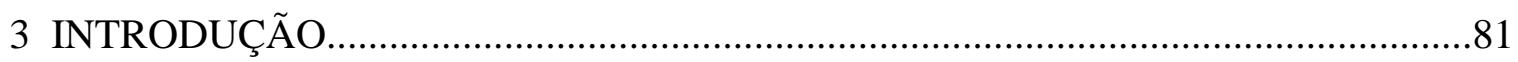

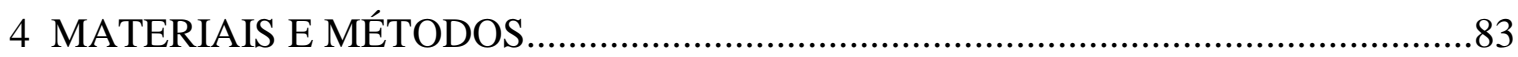

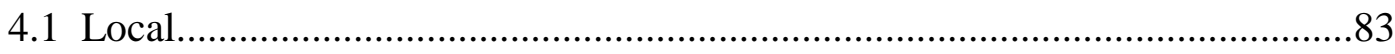

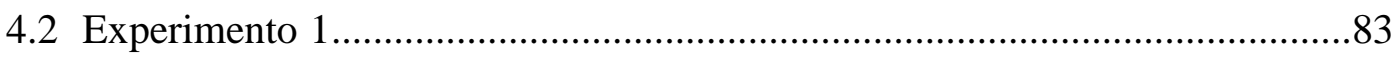

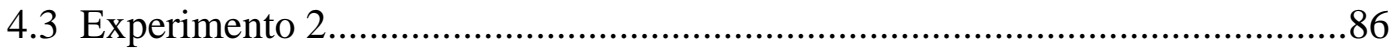

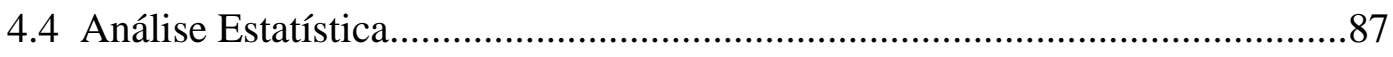

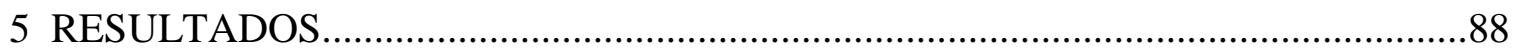

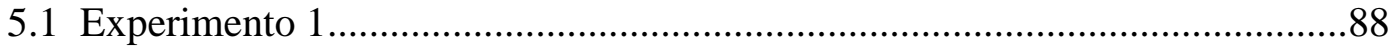

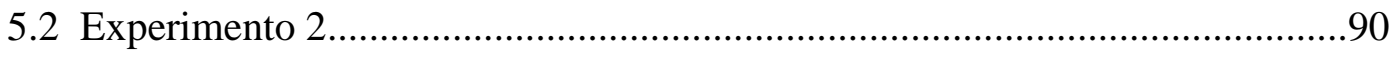




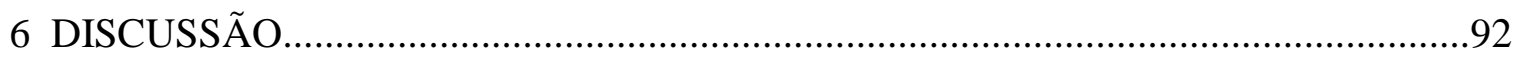

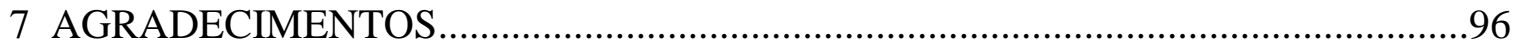

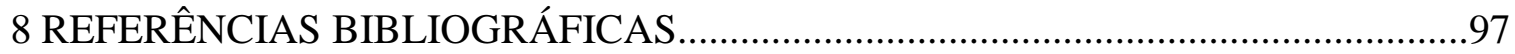

CAPÍTULO 5 - CONSIDERAÇÕES FINAIS..........................................................................101 


\title{
FISIOLOGIA E MANIPULAÇÃO DO CICLO ESTRAL DOS BOVINOS DA RAÇA CURRALEIRO PÉ-DURO
}

\author{
MSc. Rodrigo Dorneles Tortorella \\ Prof. Dr. Jairo Pereira Neves \\ Brasília, DF
}

\begin{abstract}
RESUMO
O Curraleiro Pé-Duro possui como características desejáveis, a resistência ao estresse climático, ectoparasitas e endoparasitas. Contudo, atualmente encontra-se ameaçado devido ao pequeno número de animais existentes. Uma das alternativas para expandir a criação é o uso de biotecnologias da reprodução, que podem ser adaptadas para esta raça após um maior conhecimento da fisiologia reprodutiva das fêmeas. O trabalho teve por objetivo caracterizar a dinâmica folicular durante o ciclo estral na raça Curraleiro Pé-Duro e conhecer as respostas reprodutivas frente à inseminação artificial em tempo fixo (IATF). No Capítulo 2, novilhas ( $\mathrm{n}=$ 12) e vacas $(n=11)$ não lactantes e cíclicas foram monitoradas (avaliação ultrassonográfica) diariamente durante um ciclo estral completo. Não houve diferença na dinâmica folicular entre novilhas e vacas. Desta forma, os dados foram combinados de acordo com o número de ondas foliculares. As fêmeas apresentaram predominantemente dois padrões de ondas foliculares, duas $(36,8 \%)$ e três $(63,2 \%)$, não havendo diferença na duração do ciclo estral entre estes. Nos animais com três ondas, a taxa de crescimento e máximo diâmetro do folículo ovulatório (FO) foram maiores em relação aos com duas ondas. Independentemente do padrão de ondas, a duração do FO foi menor do que do folículo dominante (FD) não ovulatório das outras ondas. O
\end{abstract}


desenvolvimento (duração e volume) do corpo lúteo (CL) não diferiu entre os animais com duas e três ondas. No Capítulo 3, as avaliações ultrassonográficas foram realizadas a cada 8 horas até 5 dias após a ovulação, em novilhas $(n=11)$ e vacas $(n=11)$ não lactantes e cíclicas, para caracterizar com maior precisão a emergência e divergência folicular. Entre vacas e novilhas houve diferença apenas no tempo entre a ovulação e emergência $(11,6 \pm 3,3 \mathrm{~h}$ versus 20,3 $\pm 2,5$ $\mathrm{h}, \mathrm{P} \leq 0,05)$ e a ovulação e divergência $(52,4 \pm 5,2 \mathrm{~h}$ versus $71,8 \pm 4,1 \mathrm{~h}, \mathrm{P} \leq 0,05)$, respectivamente. Após a emergência folicular, a divergência ocorreu em torno de 45 horas e o tamanho do $\mathrm{FD}(8,1 \pm 1 \mathrm{~mm})$ foi similar ao maior folículo subordinado (FS, 7,6 $\pm 0,9 \mathrm{~mm})$. A taxa de crescimento do FD e FS não diferiu até a divergência, sendo que após a taxa no FD manteve-se positiva enquanto que o FS regrediu. No Capítulo 4, foram verificadas as respostas foliculares e luteais de vacas cíclicas $(n=12)$, não lactantes e pluríparas frente à aplicação do benzoato de estradiol (BE) ou cipionato de estradiol (CE) como indutores da ovulação (Experimento 1), e a aplicação da gonadotrofina coriônica equina (eCG, Experimento 2) em protocolo de IATF. No Experimento 1, houve diferença apenas no momento da ovulação, sendo mais precoce e menos disperso nos animais que receberam o BE. No Experimento 2, o eCG não teve efeito benéfico sobre o crescimento folicular e luteal. Os dados obtidos no trabalho servirão de base para a manipulação do ciclo reprodutivo objetivando melhores resultados em programas de IATF e múltipla ovulação e transferência de embriões, ajudando assim na preservação e disseminação da raça.

Palavras-chave: conservação; emergência folicular; divergência folicular; recursos genéticos; ultrassonografia. 


\title{
PHYSIOLOGY AND REPRODUCTIVE CYCLE MANIPULATION OF CURRALEIRO PÉ-DURO CATTLE
}

\author{
MSc. Rodrigo Dorneles Tortorella \\ Prof. Dr. Jairo Pereira Neves \\ Brasília, DF
}

\begin{abstract}
Curraleiro Pé-Duro cattle have desirable adaptative traits as tolerance to climatic stresses and resistence to parasites. However, nowadays this breed is in dangerous due to the low number of animals. The use of reproductive biotechnologies could be an alternative to stimulate the spread of Curraleiro Pé-Duro. Although satisfactory results will just be achieved after knowledgement of female reproductive physiology. Thus, the aim of the present study was to characterize ovarian follicular dynamics during estrous cycle and reproductive responses after a fixed-time artificial insemination (FTAI). In Chapter 2, cyclic heifers $(\mathrm{n}=12)$ and non-lactating, multiparous cows (n $=11$ ) were examined daily by ultrasonography for two consecutive ovulations (an estrous cycle). Follicular and luteal characteristics were not different between heifers and cows. Consequently, data on cows and heifers were combined according to the number of follicular waves. Follicular dynamics was characterized by the predominance of two (36.8\%) and three $(63.2 \%)$ follicular waves. No difference in estrous cycle length between these follicular wave patterns was observed. The ovulatory follicle $(\mathrm{OF})$ growth rate and maximum diameter were greater $(\mathrm{P} \leq 0.05)$ in females showing three waves. The ovulatory wave was shorter $(\mathrm{P} \leq 0.05)$ than the preceding waves regardless of the wave pattern. No difference was found in corpus luteum (CL) development (volume and life-span) between females with two and three follicular wave patterns. In Chapter 3, cyclic heifers $(\mathrm{n}=11)$ and non-lactating, multiparous cows $(\mathrm{n}=11)$ were examined
\end{abstract}


every 8 hours by ultrasonography until five days after ovulation (D 0) to characterize ovarian follicular emergence and deviation. The interval from ovulation to emergence $(11.6 \pm 3.3 \mathrm{~h}$ versus $20.3 \pm 2.5 \mathrm{~h}, \mathrm{P} \leq 0.05)$ and ovulation to deviation $(52.4 \pm 5.2 \mathrm{~h}$ versus $71.8 \pm 4.1 \mathrm{~h}, \mathrm{P} \leq$ $0.05)$ was shorter in cows than in heifers, respectively. No other difference was observed between cows and heifers. DF diameter $(8.1 \pm 1 \mathrm{~mm})$ did not differ $(\mathrm{P}=0.09)$ from the largest subordinate follicle $(\mathrm{SF})$ diameter $(7.6 \pm 0.9 \mathrm{~mm})$ at the moment of deviation (around 45 hours after emergence). DF and SF growth rates were similar until deviation, at this moment SF growth rate decreased while DF growth rate remained constant. In Chapter 4, the aim was to evaluate the effects of estradiol benzoate (EB) and estradiol cypionate (CE) as ovulatory inducers (Experiment 1) and equine chorionic gonadotropin (eCG, Experiment 2) on follicular and luteal dynamics in a FTAI protocol. In Experiment 1, interval from P4 removal to ovulation was shorter and less variable in $\mathrm{EB}$ group $(\mathrm{P} \leq 0.05)$. In Experiment 2, eCG did not to improve $(\mathrm{P}>0.05)$ follicular and luteal growth. Data from this study will be useful to a better estrous cycle manipulation to achieve good results in artificial insemination, FTAI and multiple ovulation and embryo transfer programs aiming breed conservation and spread.

Key-words: conservation; follicular emergence; follicular deviation; genetic resources; ultrasonography. 


\section{LISTA DE ILUSTRAÇÕES}

\section{CAPÍTULO 1}

Figura 1.1. Exemplares de animais da raça Curraleiro Pé-Duro.

6

\section{CAPÍTULO 2}

Figura 2.1. Equação de regressão do padrão de comportamento do desenvolvimento do $1^{\circ}$ e $2^{\circ}$ folículo dominante (FD) nos animais do grupo $2 \mathrm{O}, \mathrm{A}$ e $\mathrm{B}$, respectivamente e do $1^{\circ}, 2^{\circ}$ e $3^{\circ} \mathrm{FD}$ nos animais do grupo 3O, C, D e E, respectivamente. A = 4,383041 + $2,241644 \mathrm{x}-0,277616 \mathrm{x}^{2}+0,0088 \mathrm{x}^{3}, \mathrm{R}^{2}=0,51 ; \mathrm{B}=4,27146+0,98906 \mathrm{x}-0,01846$ $\mathrm{x}^{2}, \mathrm{R}^{2}=0,89 ; \mathrm{C}=4,325581+2,731449 \mathrm{x}-0,305909 \mathrm{x}^{2}+0,008688 \mathrm{x}^{3}, \mathrm{R}^{2}=0,58 ; \mathrm{D}$ $=3,87059+2,31368 x-0,31202 x^{2}+0,01007 x^{3}, R^{2}=0,67 ; E=3,95774+1,98322$ $x-0,09814 x^{2}, R^{2}=0,91$, em que $Y=$ tamanho do FD e $x=$ dia da mensuração. As ondas foram normalizadas para o dia 0 , independentemente de ser a $1^{\mathrm{a}}, 2^{\mathrm{a}}$ ou $3^{\mathrm{a}}$.

Figura 2.2. Exemplo do padrão de crescimento do folículo dominante (FD) nos animais com duas (A) e três ondas (B) foliculares na raça Curraleiro Pé-Duro. .38

Figura 2.3. Equação de regressão do volume do CL $\left(\mathrm{mm}^{3}\right)$ ao longo do ciclo estral de fêmeas (n = 19) da raça Curraleiro Pé-Duro. $Y=787,66 x-34,44 x^{2}, R^{2}=0,93$, em que $Y=$ volume do CL e $\mathrm{x}=$ dia da mensuração.

\section{CAPÍTULO 3}

Figura 3.1. Número de folículos pequenos $(\leq 4 \mathrm{~mm})$, médios $(<4 \mathrm{a} \leq 8 \mathrm{~mm})$ e grandes $(>8 \mathrm{~mm})$ na raça Curraleiro Pé-Duro $(\mathrm{n}=22)$ nos 5 primeiros dias após ovulação. F: efeito da categoria do folículo; T: efeito do tempo; $\mathrm{F}^{*} \mathrm{~T}$ : efeito da interação categoria por 
tempo. ${ }^{\mathrm{a}, \mathrm{b}, \mathrm{c}}$ Letras diferentes sobrescritas indicam diferença em um mesmo tempo (dia). 65

Figura 3.2. Comparação do desenvolvimento do FD e FS ao longo de 4 dias após normalização dos dados para a emergência. Percebe-se uma divergência gradual no crescimento do FD $(n=22)$ e FS $(n=22)$ em que após o desvio o FS tem o crescimento interrompido e o FD continua a se desenvolver. F: efeito de categoria folicular; T: efeito do tempo; $\mathrm{F}^{*} \mathrm{~T}$ : efeito da interação tempo e categoria folicular. $\left(^{*}\right)$ Médias ( \pm DPM) com diferentes símbolos indicam diferenças $(P \leq 0,05)$ entre o FD e FS em um mesmo tempo. .66

Figura 3.3 A e B. Médias ( \pm DPM) dos tamanhos (A) e taxa de crescimento (B) do FD $(n=22)$ e FS $(n=22)$ durante a primeira onda folicular após ovulação de acordo com o momento da divergência $(0 \mathrm{~h})$. F: efeito de categoria folicular; T: efeito do tempo; F*T: efeito da interação tempo e categoria folicular. (*) Médias ( \pm DPM) com diferentes símbolos indicam diferenças $(\mathrm{P} \leq 0,05)$ entre o FD e FS em um mesmo tempo. $\left(^{\mathrm{a}, \mathrm{b}, \mathrm{c}}\right)$ Médias ( \pm DPM) com diferentes letras indicam diferenças dentro da categoria folicular em diferentes

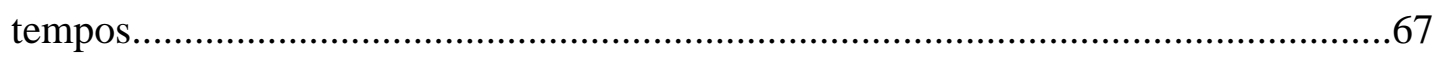

\section{CAPÍTULO 4}

Figura 4.1. Delineamento experimental. Dia 0 (D0): administração de $2 \mathrm{mg}$ IM de BE e inserção de dispositivo vaginal com $1 \mathrm{~g}$ de P4. Dia 8 (D8): retirada da P4 e aplicação do DCloprostenol Sódico (0,150 mg, IM; Controle). Grupo BE 8: semelhante ao Controle com adição de $1 \mathrm{mg}$ de BE IM no dia 8. Grupo CE 8: semelhante ao Controle com adição de $1 \mathrm{mg}$ de CE IM no dia 8. Exames ultrassonográficos foram realizados uma vez ao dia entre os dias 8 e 10 e após a cada 6 horas até a ovulação ou dia 13 (D13). 
Figura 4.2. Delineamento experimental. Dia 0 (D0): administração de $2 \mathrm{mg}$ IM de BE e inserção de dispositivo vaginal com $1 \mathrm{~g}$ de P4. Dia 8 (D8): retirada da P4, aplicação do DCloprostenol Sódico (0,150 mg, IM) e $1 \mathrm{mg}$ de BE IM (Controle). Grupo eCG: semelhante ao Controle com adição 400 UI de eCG IM. Exames ultrassonográficos foram realizados uma vez ao dia entre os dias 8 e 10 e após a cada 6 horas até ovulação ou dia 13 (D13). .88

Figura 4.3. Distribuição das ovulações após a retirada da P4 no grupo Controle, BE 8 e CE $8 . .90$ 


\section{LISTA DE TABELAS}

\section{CAPÍTULO 2}

Tabela 2.1. Características do desenvolvimento folicular e folículos dominantes (FD; média \pm EPM) dos padrões 2 e 3 ondas foliculares nas fêmeas Curraleiras Pé-Duro.

Tabela 2.2. Características do maior folículo subordinado (FS; média \pm EPM) nos padrões 2 e 3 ondas foliculares nas fêmeas Curraleiras Pé-Duro.

Tabela 2.3. Características do CL e valores médios (média \pm EPM) observados nas fêmeas Curraleiras Pé-Duro.

\section{CAPÍTULO 3}

Tabela 3.1. Características foliculares na emergência e divergência (média \pm DPM) da primeira onda folicular em vacas e novilhas Curraleiras Pé-Duro. .64

\section{CAPÍTULO 4}

Tabela 4.1. Efeito do BE e CE em um protocolo de IATF no diâmetro do folículo dominante (D8), folículo ovulatório (FO), tempo para ovulação (TOV) e taxa de ovulação (TO).

Tabela 4.2. Volume luteal $\left(\mathrm{mm}^{3}\right)$ e concentração de P4 (ng/ml) 5, 10 e 15 dias após ovulação em protocolo de IATF com aplicação de BE (BE 8) ou CE (CE8) como indutores da ovulação.

Tabela 4.3. Efeito do eCG em protocolo de IATF no diâmetro do folículo dominante (D8), folículo ovulatório (FO), tempo para ovulação (TOV) e taxa de ovulação (TO). ....92 
Tabela 4.4. Volume luteal $\left(\mathrm{mm}^{3}\right)$ e concentração de P4 (ng/ml) 5, 10 e 15 dias após ovulação em protocolo de IATF sem (Controle) e com aplicação de eCG no dia da retirada da

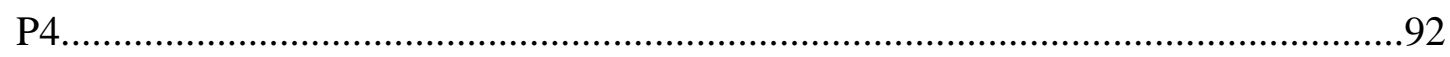




\section{LISTA DE SÍMBOLOS E ABREVIAÇÕES}

BE: benzoato de estradiol

$\mathrm{CC}$ : condição corporal

CL: corpo lúteo

DPM: desvio padrão da média

E2: estradiol-17 $\beta$

eCG: gonadotrofina coriônica equina

$\mathrm{CE}$ : cipionato de estradiol

EMBRAPA: Empresa Brasileira de Pesquisa Agropecuária

EPM: erro padrão da média

FD: folículo dominante

FO: folículo ovulatório

FS: maior folículo subordinado

FSH: hormônio folículo estimulante

FSHp: hormônio folículo estimulante purificado suíno

$g$ : força $g$

GH: hormônio do crescimento

GnRH: hormônio liberador de gonadotrofinas

h: hora

IA: inseminação artificial

IATF: inseminação artificial em tempo fixo

IFNT: interferon- $\tau$

IGF-1: fator de crescimento semelhante à insulina

IM: intramuscular

LH: hormônio luteinizante

mg: miligrama

MHz: megahertz

MLG: modelo linear generalizado

mm: milímetro

$\mathrm{mm}^{3}$ : milímetro cúbico 
MOTE: múltipla ovulação e transferência de embriões

ng: nanograma

OT: ocitocina

P4: progesterona

pg: picograma

$\mathrm{PGF}_{2 \alpha}$ : prostaglandina $\mathrm{F}_{2 \alpha}$

PIVE: produção in vitro de embriões

$\mathrm{R}^{2}$ : coeficiente de determinação

RNAm: RNA mensageiro

UI: unidade internacional

$\mathrm{V}$ : volume

VE: valerato de estradiol 
CAPÍtulo 1

INTRODUÇÃO E REVISÃO DE LITERATURA 


\section{INTRODUÇÃO}

De acordo com os últimos levantamentos (ANUALPEC, 2013) o Brasil possui o maior rebanho bovino comercial do mundo, em torno de 211,4 milhões de cabeças. Porém, grande parte deste contingente está localizada nas regiões Sul, Sudeste e Centro-Oeste, sendo que o percentual participativo de regiões com clima tropical seco é baixo. Isto se deve provavelmente pela menor oferta de alimento para os animais. Contudo, com o crescente aumento da população e da demanda por proteína animal existe a necessidade de uma maior produção de carne por parte dos pecuaristas. Considerando a perda das terras utilizadas na pecuária para o cultivo de grãos, como por exemplo, a soja, torna-se imprescindível à otimização da pecuária no que se refere à criação de um maior número de animais, em menor espaço, com menor custo e maior eficiência. Neste contexto, as regiões de clima seco ainda têm um grande potencial para ser explorado, e o uso de animais "localmente adaptados" pode ser uma alternativa de produção de carne, leite e couro a baixo custo.

O que hoje são chamadas de raças "locais ou nativas", na verdade são os bovinos originados a partir dos animais trazidos por portugueses e espanhóis durante a colonização (Primo, 1992), sendo os mesmos selecionados naturalmente nos diversos ecossistemas brasileiros. Durante estes 500 anos de seleção estes animais desenvolveram características únicas de adaptação às condições climáticas, sanitárias e de manejo aos diversos ecossistemas do Brasil (Egito et al., 2002). Contudo a intensa seleção genética, realizada por cruzamentos absorventes, realizada durante o século 20, utilizando raças exóticas criadas em clima temperado (Bos taurus) e raças zebuínas (Bos indicus), como o Nelore, fez com que as raças locais fossem sendo substituídas, aproximando-se da extinção. 
O bovino Curraleiro Pé-Duro é descendente dos bovinos trazidos pelos colonizadores portugueses e espanhóis (Mariante \& De Bem 1992, Boaventura et al., 2005). Acredita-se que tenha descendência direta da raça Mirandesa, a qual ainda pode ser encontrada na região de Trás-os-Montes em Portugal. Desde sua chegada ao Brasil têm sua criação baseada em regime extensivo, sem um manejo sanitário e nutricional adequado, tornando-se extremamente rústico e adaptado a ambientes secos como as planícies do semiárido do Nordeste brasileiro (Serrano et al., 2004; Bianchini et al., 2006). Ou seja, a raça pode ser trabalhada sem grandes investimentos em regiões com pastagens naturais de baixa qualidade, nas quais outras raças teriam dificuldade até mesmo de sobrevivência.

Os criadores definem o gado Curraleiro Pé-Duro como animais que apresentam alta prolificidade, precocidade, adaptabilidade, habilidade materna e resistência a doenças e ectoparasitas (Mariante \& De Bem, 1992; Egito et al., 2002). Entretanto, essas afirmativas não são cientificamente comprovadas. Portanto, para se determinar a eficiência reprodutiva faz-se necessário o conhecimento sobre a fisiologia do ciclo estral, do anestro pós-parto, e das respostas fisiológicas frente às biotecnias da reprodução, como por exemplo, a IATF.

A partir do conhecimento destes eventos fisiológicos poderão ser utilizadas estratégias de manejo que visem à preservação, difusão e cruzamentos da raça, mediante sua participação em programas de melhoramento genético.

\subsection{Objetivos}

\subsubsection{Geral}

Caracterizar alguns dos eventos (ou os principais eventos) que concernem à fisiologia do ciclo estral em vacas pluríparas, cíclicas e não lactantes e novilhas da raça Curraleiro Pé-Duro e avaliar a resposta desses animais a protocolos de sincronização do estro e indução da ovulação durante o período das águas e da seca. 


\subsubsection{Específicos}

Caracterizar a dinâmica folicular (emergência, divergência e dominância) e luteal de novilhas e vacas Curraleiras Pé-Duro durante o ciclo estral (intervalo de duas ovulações);

Avaliar a resposta folicular e luteal a protocolos de sincronização do estro e indução da ovulação com o benzoato (BE) e o cipionato de estradiol (CE) em vacas Curraleiras Pé-Duro durante o período com maior oferta forrageira (época das águas);

Avaliar o efeito da aplicação da gonadotrofina coriônica equina (eCG), no crescimento folicular e luteal, em protocolos de sincronização e indução da ovulação em vacas Curraleiras Pé-Duro durante o período com menor oferta forrageira (época da seca). 


\section{REVISÃO DE LITERATURA}

\subsection{Origem e Características Raciais do Curraleiro Pé-Duro}

Após a colonização, em meados do século XVI, coube a Tomé de Souza, primeiro Governador Geral do Brasil, a missão de introduzir a espécie bovina na nova colônia já que nela não haviam animais domesticados para produção de leite e carne. Os primeiros bovinos foram transportados da Península Ibérica, em navios negreiros, desembarcando nas capitanias hereditérias, onde hoje se localizam os estados de Pernambuco, Bahia e São Paulo (Velloso, 1996). Registra-se que os mesmos pertenciam a três subespécies: Bos taurus aquitanicus, Bos taurus ibericus e Bos taurus batavicus. Estes primeiros animais povoaram os campos nativos brasileiros adaptando-se ao clima e vegetação, dando origem a grandes rebanhos com diversas variedades genéticas. Algumas destas raças estão presentes na atualidade e melhoradas geneticamente (Primo, 1992).

O bovino conhecido hoje em dia como Curraleiro Pé-Duro tem origem destes animais trazidos há 500 anos, sendo descendente da união de raças portuguesas como a Alentajana e Galena, e raças espanholas pertencentes ao tronco Bos taurus aquitanicus. De maneira mais precisa relata-se que estes bovinos descendem da raça Mirandesa, particularmente da variedade Beiroa, encontrada ainda hoje nas províncias de León e Trás-os Montes, na Espanha e Portugal, respectivamente (Carvalho \& Girão, 1999). Entretanto, é possível que outros grupamentos genéticos tenham participado da formação do Curraleiro Pé-Duro, porém naquela época ainda não eram estabelecidos como raça. 
Os animais têm como características raciais (Figura 1.1): peso mínimo de $380 \mathrm{~kg}$ para os machos e $300 \mathrm{~kg}$ para as fêmeas; altura mínima de 1,34 m para os machos e 1,20 m para as fêmeas; as pelagens mais comuns são a baia e vermelha clara, sendo as extremidades como vassoura da cauda e focinho, pretos, podendo alguns apresentar manchas escuras ao redor dos olhos. A cabeça pequena apresenta cornos curtos a médios em forma de coroa, sendo as orelhas pontudas, pequenas e revestidas com pêlos claros. Possuem barbela e umbigo reduzidos além de membros delgados (Britto, 1998; Boaventura et al., 2005; Santini, 2008).

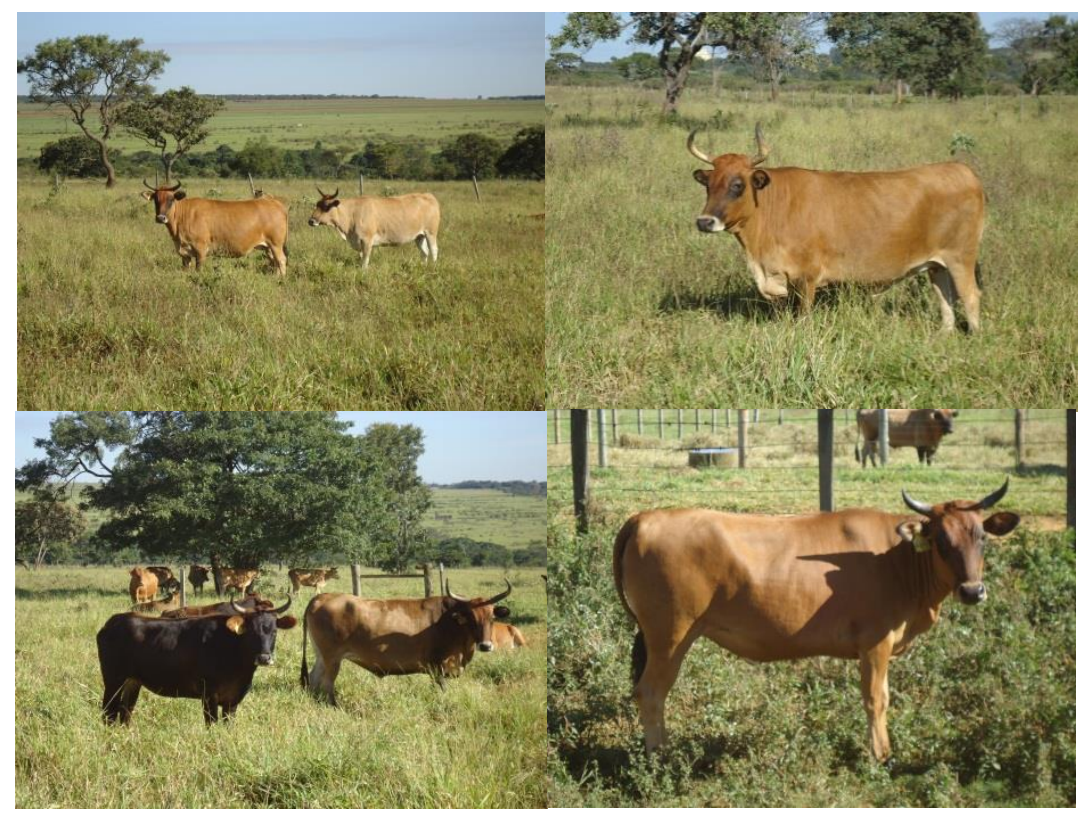

Figura 1.1. Exemplares de animais da raça Curraleiro Pé-Duro.

A raça é oriunda de sistemas de criação extensivos, com pouco ou nenhum cuidado sanitário, pastagens de baixa qualidade, baixa umidade e altas temperaturas, resultando em animais rústicos e resistentes a condições desfavoráveis. Características como resistência a doenças em geral, intoxicações, ecto e endoparasitas (Mariante \& Egito, 2002), baixa mortalidade de bezerros e abortos são descritas pelos proprietários. As perspectivas futuras de mercado indicam que o consumidor cada vez mais será exigente quanto à carne ingerida, e que o uso de produtos químicos se tornará o mínimo possível. Por isso a maior resistência a doenças em geral é um grande atrativo para a raça que necessita de menor quantidade de medicamentos, sendo um diferencial de mercado (Fioravanti et al., 2008).

Os animais muitas vezes são discriminados pelo pequeno porte e preteridos por outros com maior rendimento de carcaça (Rangel et al., 2004). Entretanto esta morfologia é uma 
adaptação a regiões com déficit alimentar e hídrico. Tanto que em épocas de estresse nutricional apesar de perderem peso, não adoecem e recuperam-se rapidamente quando as condições melhoram. Isto porque aproveitam bem todos os tipos de pastagens e sem a necessidade de suplementação alimentar. Já animais de raças comerciais melhoradas geneticamente em situação semelhante perdem peso rapidamente, diminuem a eficiência reprodutiva e tornam-se mais susceptíveis a doenças pela queda da imunidade (Bianchini et al., 2006). Desta forma o Curraleiro Pé-Duro tem um bom custo-benefício já que não exige grandes investimentos e tem baixo custo de produção, sendo adequado para pequenos e médios produtores (Primo, 1992; Mariante \& Cavalcante, 2000).

Como ferramenta para preservação e difusão da raça, o Curraleiro Pé-Duro poderia estar sendo incluído em programas de melhoramento genético com o objetivo de aumentar a resistência a doenças (Rangel et al., 2004; Gibson \& Bishop, 2005). Existem trabalhos que relatam as vantagens do cruzamento de raças "locais" com européias e zebuínas, nos quais a F1 apresentou maior ganho de peso, melhor conversão alimentar, melhor composição de carcaça e precocidade (Mujica et al., 1995; Nardon et al., 1996; Euclides Filho, 2000).

Estas qualidades transformam a raça em um tesouro genético com 500 anos de seleção natural, podendo ser uma alternativa a ambientes desfavoráveis para outras raças bovinas.

\subsection{Conhecimento da Fisiologia Reprodutiva no Manejo Genético de Pequenas Populações}

A partir do século XX com o crescimento populacional, aumento da urbanização e poder aquisitivo da população, houve um grande aumento na demanda por proteína animal. Isto levou a uma maior importação de raças Européias e Zebuínas e, por conseguinte, o cruzamento sem planejamento destas com algumas raças "locais", levando ao risco de extinção destas últimas (Mariante \& Egito, 2002). A possibilidade da extinção da raça é uma grande ameaça ao futuro conhecimento de informações genéticas armazenadas ao longo de 500 anos de seleção natural em seu DNA (Mariante \& Cavalvante, 2000). Com o objetivo de evitar esta grande perda para a ciência, a Embrapa Biotecnologia e Conservação de Recursos Genéticos (Cenargen) vem realizando pesquisas em parceria com instituições Federais, Estaduais e particulares, para 
proteger este patrimônio genético. Atualmente a conservação se dá por meio de bancos de material genético em laboratórios (ex situ) e núcleos de criação (in situ), ambos espalhados pelas instituições parceiras. O programa de conservação inclui as etapas de: identificação de populações em estado avançado de diluição genética, caracterização fenotípica e genética do germoplasma e avaliação do potencial produtivo das raças "locais" (Mariante et al., 2000). Estima-se que existam em torno de 5.000 bovinos Curraleiro Pé-Duro distribuídos nos estados do Maranhão, Piauí, Bahia, Pará, Tocantins e Goiás, sendo mantido pela EMBRAPA um núcleo de conservação in situ em São João do Piauí (PI, Fioravanti et al., 2008). A partir de 2009, foi instituída a Rede Pró-Centro-Oeste que tem como metas principais: obter maior conhecimento nas raças Curraleiro Pé-Duro e Pantaneiro com objetivo inicial de preservação e uso sustentável dos recursos naturais do Cerrado e Pantanal, e contribuir para formação de recursos humanos para o desenvolvimento sustentável da região Centro-Oeste. A rede contempla linhas de pesquisas que incluem um programa de pós-graduação em nível de doutorado e mestrado, integrando os estados da região Centro-Oeste, e fomentando assim o estudo das raças citadas.

Após alcançar o objetivo de preservação é importante concentrar esforços na inclusão das raças locais no ambiente da pecuária moderna, sempre atentando para questões como viabilidade econômica, sustentabilidade e cenário geral de inclusão das mesmas. Em um cenário presente e futuro da pecuária mundial, os sistemas de produção ecologicamente corretos ganham força, nos quais o produtor deve ofertar produto de qualidade e segurança alimentar com responsabilidade social. Algumas pesquisas prospectivas da pecuária bovina apontam diretrizes para o futuro como: a introdução de novo material genético que aumente a eficiência reprodutiva, com menor tamanho corporal e maior resistência natural a carrapatos (Nehmi Filho, 2003; Nogueira, 2003). Ou seja, a criação do Curraleiro Pé-Duro pode ser uma alternativa para determinadas áreas da propriedade e núcleos de mercado, que com uma boa ação de marketing, pode ter valor agregado, não sendo um concorrente direto as raças exóticas comerciais.

Para a concretização da idéia de preservação e aumento do número de animais nos núcleos de criação e fazendas comerciais, há a necessidade da adoção de técnicas de manejo e uso de biotecnologias com o objetivo de aumentar a eficiência reprodutiva. Estes manejos como, por exemplo, rotação de touros entre fazendas, adoção de estação de monta e inseminação artificial em tempo fixo (IATF) visam o aumento do número de animais com maior variabilidade 
genética. Desta maneira a consanguinidade, que é um grande problema enfrentado pelos criadores do Curraleiro Pé-Duro atualmente, teria uma diminuição.

Para a introdução da raça em novos ambientes e desenvolvimento de projetos pecuários que visem a conservação e lucro ao proprietário, é importante que as estratégias de manejo sejam embasadas em pesquisas. Para tanto, para adoção de um manejo reprodutivo eficiente que vise à multiplicação do material genético, é necessário um conhecimento amplo a respeito da fisiologia reprodutiva. Contudo, ainda não existem informações sobre a mesma na raça, como duração do estro, período de ocorrência do mesmo (diurno, noturno), número de folículos na emergência da onda, tamanho folicular na divergência, e ovulatório, concentração de progesterona durante o ciclo estral, tempo de gestação e duração do anestro pós-parto, por exemplo.

O ciclo estral na vaca é caracterizado por modificações cíclicas e morfológicas em seus órgãos reprodutivos e comportamento sexual. Os bovinos são animais classificados como poliestricos anuais, ou seja, ciclam durante todos os meses do ano, a partir da puberdade, e em condições adequadas de criação. Seu ciclo estral tem duração de 18 a 24 dias, com média de 21 dias. O mesmo é dividido em quatro fases: pró-estro, com duração média de três dias; estro, de seis a 18 horas; metaestro, de dois dias e diestro, com duração de 15 dias (Hafez \& Hafez, 2004).

No período médio de 21 dias, os eventos dentro do ovário são dinâmicos e caracterizados por ondas foliculares, geralmente de dois a três (Ginther et al., 1989), em que um grupo de folículos antrais, estimulados pelo hormônio folículo estimulante (FSH; Driancourt, 2001; Ginther et al., 1996), crescem em média três dias (emergência folicular) até um folículo se torne dominante e os demais entrem em atresia (divergência folicular; Ginther et al., 2001).

O folículo dominante, após a divergência, possui uma intensa capacidade de síntese de inibina e estradiol-17 $\beta$ (E2), fazendo um feed-back negativo ao FSH e consequente diminuição de sua concentração circulante. O mecanismo de ação do feed-back negativo se dá pela diminuição da expressão do gene que codifica a subunidade $\beta$ do FSH, por diminuir a transcrição e estabilidade do RNA mensageiro (RNAm) (Driancourt, 2001; Hurk \& Zhao, 2005).

A partir do estabelecimento da dominância, o folículo passa a expressar receptores funcionais para o hormônio luteinizante $(\mathrm{LH})$ nas células da granulosa e se torna dependente do mesmo (Ginther et al., 1996; Evans \& Fortune, 1997). O mecanismo de síntese envolve a estimulação da teca interna pelo LH produzindo testosterona, que captado pelas células 
da granulosa será transformado em E2 através da enzima P450 aromatase (Ginther et al., 1996; Driancourt, 2001; Hafez \& Hafez, 2004). Nos folículos antrais que se destinam à atresia, as células da granulosa perdem esta habilidade de aromatização levando ao acúmulo de hormônio masculino no líquido folicular (Pimentel, 2002).

Com a dominância, o folículo se destina a ovulação ou a atresia. No caso de encontrar um ambiente endócrino com altas concentrações de progesterona (P4), ou seja, presença de corpo lúteo (CL), o folículo irá regredir pela inibição da pulsatilidade de LH, começando uma nova onda folicular (Adams et al., 1992). Porém, após a luteólise e consequente queda nas concentrações de progesterona, e aumento na pulsatilidade de LH, o folículo préovulatório tem seu crescimento terminal, liberando maiores quantidades de E2 para circulação sanguínea. O pico na produção de E2 desencadeia um feed-back positivo no hipotálamo e hipófise, estimulando os picos do hormônio liberador de gonadotrofinas (GnRH) e do LH, respectivamente, culminando na ovulação (Ginther et al., 2001). Com relação ao pool de folículos ovarianos pré-antrais e antrais apenas 0,1\% destes alcança a etapa da ovulação (Ireland, 1987; Webb et al., 2007; Moraes et al., 2008).

A estrutura denominada folículo após o pico pré-ovulatório de LH dá origem a outra chamada de CL. Para isto, ocorrem mudanças estruturais e bioquímicas nas células da teca e granulosa, resultando na luteinização das mesmas. O CL formado é constituído de dois tipos celulares, as células luteínicas pequenas, que se originam da teca interna, e as células luteínicas grandes, advindas da camada granulosa, sendo ambas as produtoras de progesterona (P4; Meidan et al., 1990).

Se o oócito liberado na ovulação não for fecundado, o mecanismo de luteólise se torna ativo levando a liberação de prostaglandina $\mathrm{F}_{2 \alpha}\left(\mathrm{PGF}_{2 \alpha}\right)$ pelo útero e um novo ciclo inicia. O mecanismo da regressão luteal não está totalmente esclarecido, mas acredita-se que entre outros motivos, se deva pela redução local do fluxo sanguíneo. Isto devido a uma degeneração dos capilares luteais ocasionada pela liberação de $\mathrm{PGF}_{2 \alpha}$, levando à isquemia e falta de nutrição para as células do CL (Cunningham, 1999; Spinosa et al., 2002). Durante a fase inicial e média da vida do CL, a ligação da P4 em seus receptores no endométrio inibe a expressão de receptores de E2 e consequentemente de ocitocina (OT). Em determinado momento, os receptores de P4 sofrem um down-regulation não inibindo satisfatoriamente os receptores de E2 e OT. Com isso a ligação do E2 em seus receptores aumenta à expressão de receptores de OT e consequentemente a 
produção de $\mathrm{PGF}_{2 \alpha}$ (Senger, 2003). No caso de ocorrer à fecundação, o embrião sintetiza e secreta fatores fibroblásticos como o interferon- $\tau$ (IFNT), entre os dias 12 a 26, com pico entre os dias 15 e 16 (Roberts et al., 1991), que impedem a liberação de PGF $_{2 \alpha}$ pelo endométrio, mantendo o CL e a produção de P4 (Cunningham, 1999).

Com o conhecimento do desenvolvimento folicular e hormonal foi descoberto que vacas Bos indicus e Bos taurus se comportavam de maneira diferente quanto à duração de estro (Mizuta, 2003), número de ondas foliculares (Bo et al., 2003; Wolfenson et al., 2004), tamanho folicular na divergência (Ginther et al., 1996; Castilho et al., 2006), tamanho folicular com capacidade ovulatória, tamanho de folículo ovulatório (Sartori et al., 2001; Gimenes et al., 2008), tamanho do CL e concentração de P4 (Segerson et al., 1984; Figueiredo et al., 1997).

Desta maneira é possível que haja diferenças na fisiologia reprodutiva também

entre estas raças melhoradas geneticamente e o Curraleiro Pé-Duro que foi selecionado naturalmente. Esta informação é importante para o desenvolvimento de estratégias reprodutivas que manipulam o ciclo estral com a utilização de hormônios. Carvalho et al. (2008) relatam que novilhas Nelore são mais sensíveis a altas concentrações de P4 durante manipulação hormonal, influenciando negativamente no crescimento do folículo dominante. Desta maneira é aconselhada a aplicação de $\mathrm{PGF}_{2 \alpha}$ no início de um protocolo de IATF. Outro exemplo da importância do conhecimento da fisiologia na aplicação de biotecnias é o uso de indutores de ovulação a base do hormônio regulador do crescimento $(\mathrm{GnRH})$ em vacas de alta produção leiteira e o não uso de derivados do E2. Isto porque o aumento de fluxo sanguíneo hepático e consequente maior metabolismo de esteroides nesta categoria animal, altera a sincronização da ovulação, duração de estro e momento do pico de LH (Sartori et al., 2004).

\subsection{A IATF como Técnica Reprodutiva Multiplicadora da Genética do Curraleiro Pé-Duro}

O incentivo a criação do Curraleiro Pé-Duro por parte dos pecuaristas deve se basear além do conceito de preservação, na disseminação e multiplicação da genética da raça. Neste sentido é fundamental que a propriedade busque a maior eficiência reprodutiva possível, o que consequentemente estaria levando a um melhor desempenho produtivo e maior retorno 
econômico. Sendo assim, o uso de programas reprodutivos que fazem o uso da IATF parecem ser um bom caminho na busca pela maior rentabilidade do sistema pecuário.

A IATF se caracteriza pelo uso de combinações hormonais que objetivam a manipulação e aumento da fertilidade do estro induzido, e da precisão do momento da ovulação (Borges et al., 2008; McKinniss et al., 2011; Sales et al., 2011). Além das vantagens da IA que agrega valores genéticos e econômicos com o uso de touros superiores geneticamente, a IATF concentra a mão-de-obra da propriedade, sincroniza e induz a ciclicidade dos animais. Desta forma um maior número de vacas é inseminado no início da temporada de monta aumentando a proporção de prenhez, o que possibilita maior tempo de recuperação para nova gestação na temporada seguinte (Da Silva et al., 2007; Penteado et al., 2008; Torres-Júnior et al., 2009). Além disso, os bezerros nascidos de IATF no início da temporada de parição são mais pesados ao desmame, aumentando a lucratividade do produtor (Bó et al., 2005; Loguércio, 2005).

$\mathrm{O}$ uso da IATF, além dos efeitos benéficos diretos como alguns mencionados acima, traz também uma grande importância em relação aos efeitos indiretos principalmente em pequenos e médios criadores. Ou seja, para o uso desta biotécnica com um resultado favorável é necessário que o criador alcance pré-requisitos mínimos em sua propriedade como: bom manejo nutricional, quantidade e qualidade de pastagens, bom status sanitário, boa administração e organização da propriedade, melhorias nas instalações (curral, cercas, aguadas, cochos), além de treinamento para os funcionários (Gonçalves et al., 2008).

Os protocolos hormonais descritos na literatura têm resultados que variam dependendo da condição sanitária e nutricional do rebanho (Borges et al., 2008; Baruselli et al., 2012; Sá Filho et al., 2013). Ou seja, para cada propriedade existe um protocolo hormonal que se adequará melhor, devendo-se levar em consideração as condições individuais de cada rebanho, além do custo/benefício do seu uso (Moraes et al., 2008).

Os hormônios utilizados nos programas hormonais de IATF são os progestagenos (P4 ou derivados), os derivados do E2, a gonadotrofina coriônica equina (eCG), o hormônio folículo estimulante purificado suíno (FSHp), a $\mathrm{PGF}_{2 \alpha}$, e o $\mathrm{GnRH}$. O controle da reprodução com estes fármacos só foi possível devido ao conhecimento e estudo da fisiologia hormonal e folicular permitindo assim o controle racional da reprodução. Este controle possibilitou manipular o ciclo estral, induzir o estro pós-parto e aprimorar outras biotecnias reprodutivas tais como a múltipla ovulação e transferência de embriões (MOTE) e a produção in vitro de embriões (PIVE). 
Os progestagenos têm como funções diminuir a ocorrência de ciclos curtos após a primeira ovulação no pós-parto e ajudam a restabelecer a ciclicidade (Cooper et al., 1991; Fike et al., 1997; Perry et al., 2004; Meneghetti et al., 2009). Os ciclos curtos devido à luteólise prematura são decorrentes de uma liberação precoce de $\mathrm{PGF}_{2 \alpha}$ por um número insuficiente de receptores de progesterona no endométrio (Zollers et al., 1993). A partir do momento da exposição ao progestagenos exógeno e consequente aumento de receptores para progesterona no útero, os receptores de ocitocina são inibidos impedindo a liberação de $\mathrm{PGF}_{2 \alpha}$ (Leung \& Wathes, 2000). Seu uso também objetiva diminuir a pulsatilidade de LH, suprimindo o estro e impedindo que haja uma ovulação durante sua permanência assim como auxilia na regressão do folículo dominante da onda antiga. A partir do momento em que ocorre a interrupção da exposição a este hormônio, desencadeia-se uma estimulação a pulsatilidade de LH, levando ao crescimento do folículo ovulatório e ovulação (Moraes et al., 2008). Contudo, a utilização dos progestagenos além do período recomendado (7-9 dias) pode levar à formação de folículos persistentes. Estes folículos são expostos a contínuas doses subluteais de P4 que acabam por prolongar o período de dominância do mesmo, resultando na diminuição da capacidade ovulatória e da competência meiótica do oócito. Tem como diferencial dos outros folículos maior número de camadas de células da granulosa e da teca o que contribui para as altas concentrações de estradiol secretadas, além de seus oócitos terem baixa fertilidade (Fortune \& Rivera, 1999).

Para evitar a persistência do folículo dominante faz-se a associação dos progestagenos aos derivados do E2 que levam à regressão do mesmo e surgimento de uma nova onda folicular com grande potencial de poder fecundante (Bó et al., 2000). Os estrógenos utilizados com maior frequência são o benzoato de estradiol (BE), cipionato de estradiol (CE) e o valerato de estradiol (VE). Estes regridem os folículos LH-dependentes por sua interação com a P4 e FSH dependentes por si só (Martinez et al., 2005), culminando em nova onda folicular após 2,5 a 6 dias de sua aplicação dependendo da meia-vida do derivado do E2 utilizado (Bo et al., 2000; Siqueira et al., 2009; Sá Filho et al., 2011).

Após a retirada do progestagenos é importante que não exista corpo lúteo funcional, o que impediria a manifestação de estro e ovulação. Para tanto é feita a aplicação da $\mathrm{PGF}_{2 \alpha}$ que tem ação luteolítica (Spinosa et al., 2002) em corpos lúteos com idade superior a cinco dias (Rathbone et al., 2001). 
$\mathrm{O}$ eCG e mais recentemente o FSHp, tem sido utilizados no final do protocolo de IATF com o objetivo de estimular o crescimento folicular final, aumentando as chances de ovulação. Em Bos taurus, o folículo adquire capacidade ovulatória quando maior que $10 \mathrm{~mm}$ (Sartori et al., 2001), ao passo que em Bos indicus os folículos em torno de 7 e 8,4 mm já apresentam responsividade ao LH (Gimenes et al., 2008). O eCG é o hormônio produzido pelos cálices endometriais da égua entre os dias 40 a 120 de gestação. Sua função primordial é estimular a manutenção do corpo lúteo primário e levar a luteinização dos folículos secundários, formando assim corpos lúteos acessórios que ajudam a elevar a concentração de progesterona até que a placenta seja a fonte principal da produção deste hormônio (Neely et al., 1983, Senger, 2003). Esta propriedade do eCG é devida à sua ação nos receptores de LH, porém o mesmo possui atividade como FSH em outras espécies também, estimulando a esteroidogênese e o crescimento folicular (Neely et al., 1983, Senger, 2003; Duffy et al., 2004). Pesquisadores relatam que a aplicação de eCG no momento da retirada do implante de progesterona, aumenta a taxa de prenhez (Bó et al., 2003; Baruselli et al., 2004a; Sá Filho et al., 2010) em diferentes períodos pós-parto (Rodrigues et al., 2004; Ayres et al., 2007). Entretanto seu uso é fundamental para animais com baixa condição corporal $(\mathrm{CC}<3)$, provavelmente devido à baixa frequência de pulsos de LH, principalmente em animais em anestro pós-parto (Baruselli et al., 2004b).

Uma alternativa ao eCG no estímulo ao crescimento folicular e secreção das gonadotrofinas endógenas é o desmame temporário. O desmame temporário é utilizado com o objetivo de diminuir o efeito negativo da cria ao pé na liberação de GnRH/LH no pós-parto (Stagg et al., 1998). Quando bem realizado, ajuda no manejo da IA, na detecção de estro, além de potencializar o restabelecimento da ciclicidade. O mesmo consiste no aparte total do bezerro por um período entre 48 e 120 horas a depender do protocolo hormonal (Borges et al., 2009; Perea et al., 2009; Sá Filho et al., 2009b). É importante ressaltar que este tipo de desmame deve ser realizado dentro de um tratamento hormonal bem estabelecido, o que leva ao aumento da taxa de prenhez (Geary et al., 2001; Sá Filho et al., 2009b; Vasconcelos et al., 2009), pois, se realizado isoladamente, produz resultados inconsistentes (Loguércio, 2005).

Uma das grandes vantagens da IATF é a não necessidade da detecção do estro, um dos entraves da IA convencional, sendo assim uma alternativa em propriedades, que não dispõem de um manejo adequado e profissional experiente, para detecção de estro. Para realização da IATF é importante conhecer o momento da ovulação podendo ser usados hormônios indutores da 
ovulação como o GnRH, o BE e o CE no final do protocolo. Após o GnRH ser aplicado, o pico de LH ocorre por volta de 20 a 120 minutos (Lucy \& Stevenson, 1986; Haughian et al., 2004), a ovulação entre 24-36 horas (Tortorella et al., 2013) e a IATF deve ser realizada em 16-18 horas (Lucy \& Stevenson, 1986; Pursley et al., 1995), enquanto que quando o BE é utilizado o pico acontece entre 16 e 24 horas (Lamoglia et al., 1998) e a ovulação em torno de 40 horas (Hanlon et al., 1997), sendo a IATF realizada após 30 horas quando o BE aplicado um dia após a retirada da P4 ou 48 horas após se aplicado no dia da retirada (Ayres et al., 2008). Já com o CE o pico de LH ocorre por volta de 30-35 horas e a ovulação após 55 horas (Geary et al., 2001), sendo a IATF feita após 48-60 horas (Colazo et al., 2004; Sá Filho et al., 2009a).

No contexto da criação das raças localmente adaptadas, como o Curraleiro PéDuro, a implantação da IATF terá algumas barreiras a serem vencidas, como a necessidade de uma maior organização da propriedade como um todo. Em muitas propriedades não é feito um bom manejo nutricional, sanitário e zootécnico, sendo estes fundamentais para bons resultados. $\mathrm{O}$ treinamento dos funcionários no trato com os animais durante as manipulações hormonais prevenindo o estresse desnecessário é outro tópico que deverá ser melhorado. Contudo, o grande desafio é estimular o proprietário a investir nesta nova tecnologia que trará custos que antes não existiam. Ou seja, mostrar a maior rentabilidade da sua atividade se ele der o mínimo de condições para a raça demonstrar todo seu potencial econômico em condições especiais. 


\section{REFERÊNCIAS BIBLIOGRÁFICAS}

ADAMS, G.P.; MATTERI, R.L.; KASTELIC, J.P. et al. Association between surges of follicle stimulating hormone and the emergence of follicular waves in heifers. Journal of Reproduction and Fertility, v. 94, p. 177-188, 1992.

AMSTALDEN, M.; GARCIA, M.R.; STANKO, R.L. et al. Central infusion of recombinant ovine leptin normalizes plasma insulin and stimulates a novel hypersecretion of luteinizing hormone after short-term fasting in mature beef cows. Biology of Reproduction, v. 66, p. 15551561, 2002.

ANUÁRIO DA PECUÁRIA BRASILEIRA / CIÊNCIAS DA TERRA / CIÊNCIAS AGRÁRIAS, PECUÁRIA, PESCA E PSCICULTURA. ANUALPEC. 20.ed. Brasil: FNP, 2013.

AYRES, H.; MARQUES, M.O.; SILVA, R.C.P. et al. Influência do uso de eCG em diferentes períodos pós-parto e do escore de condição corporal na taxa de prenhez da vacas Nelore inseminadas em tempo fixo. In: XXI REUNIÃO ANUAL DA SOCIEDADE BRASILEIRA DE TECNOLOGIA DE EMBRIÕES, 35. (Suplemento 3), 2007, Salvador, BA. Anais... Salvador, SBTE, 2007. p. 1113.

AYRES, H.; MARTINS, C.M.; FERREIRA, R.M. et al. Effect of timing of estradiol benzoate administration upon synchronization of ovulation in suckling Nelore cows (Bos indicus) treated with a progesterone-releasing intravaginal device. Animal Reproduction Science, v. 109, p. 77 87, 2008.

BARTLETT, O.P.C.; KIRK, J.; COE, P. et al. Descriptive epidemiology of anestrous in michiganholstein-friesian cattle. Theriogenology, v. 27, p. 459-476, 1987.

BARUSELLI, P.S.; REIS, E.L.; MARQUES, M.O. et al. The use of hormonal treatmens to improve reproductive performance of anestrous beef cattle in tropical climates. Animal Reproduction Science, v. 82-83, p. 479-486, 2004a.

BARUSELLI, P.S.; MADUREIRA, E.H.; MARQUES, M.O. et al. Efeito do tratamento com eCG na taxa de concepção de vacas Nelore com diferentes escore de condição corporal inseminadas em tempo fixo. Acta Scientiae Veterinaria, v. 32, p.228, 2004b. 
BASTOS, G.M.; BRENNER, R.H.; WILLKE F.W. et al. Hormonal induction of ovulation and artificial insemination in suckled beef cows under nutritional stress. Theriogenology, v. 62, p. 847-853, 2004.

BELLOWS, R.A.; SHORT, R.E.; RICHARDSON, G.V. Effects of sire, age of dam and gestation feed level on dystocia and postpartum reproduction. Journal of Animal Science, v. 55, p. 1827, 1982.

BIANCHINI, E.; CONCEPTA, M.; LUCCI, C.M. et al. Características corporais associadas com a adaptação ao calor em bovinos naturalizados brasileiros. Pesquisa Agropecuária Brasileira, v. 41, p. 1443-1448, 2006.

BISHOP, D.K.; WETTEMANN, R.P.; SPICER, L.J. Body energy reserves influence the onset of luteal activity after early weaning of beef cows. Journal of Animal Science, v. 72, p. 2703-2708, 1994.

BO, G.A.; BARUSELLI, P.S.; MARTINEZ, M.F. Pattern and manipulation of follicular development in Bos indicus. Animal Reproduction Science, v. 78, p. 307-326, 2003.

BO, G.A.; BERGFELT, D.R.; BROGLIATTI, G.M. et al. Local versus systemic effects of exogenous estradiol-17[beta] on ovarian follicular dynamics in heifers with progestogen implants. Animal Reproduction Science, v. 59, p. 141-157, 2000.

BO, G.A; CUTAIA, L.; CHESTA, P. et al. Implementacion de programas de inseminación artificial en rodeos de cria de Argentina. In: VI SIMPÓSIO INTERNACIONAL DE REPRODUCCIÓN ANIMAL, Córdoba , Argentina. Córdoba: IRAC, p. 97-128, 2005.

BOAVENTURA, V.M. Gado Curraleiro: relação dos criadores e aspectos gerais da raça. Goiânia: Sebrae - GO, 2005. 80 p.

BORGES, L.F.K.; FERREIRA, R.; SIQUEIRA, L.C. et al. Sistema para inseminação artificial sem observação de estro em vacas de corte amamentando. Ciência Rural, v. 39, n. 2, p. 496-501, 2008.

BRITTO, C.M.C. Citogenética do gado Pé-Duro. Teresina: EDUFPI, 1998, 94 p.

BYERLEY, D.J.; WHISNANT, C.S.; DEAN, R. et al. Hypothalamic Proopiomelanocortin mRNA levels in suckled or nunsuckled beef cows: a preliminary study. Theriogenology, v. 40, p. 661-668, 1993.

CARVALHO, J.H.; GIRÃO, R.N. Conservação de recursos genéticos animais: a situação do bovino Pé-duro ou Curraleiro. In: SIMPÓSIO DE RECURSOS GENÉTICOS PARA A AMÉRICA LATINA E CARIBE. SIRGEAL, 2., 1999, BRASILIA. Anais eletrônicos... [CD ROM], Brasília: EMBRAPA Recursos Genéticos e biotecnologia, 1999. 
CARVALHO, J.B.P.; CARVALHO, N.A.T.; REIS, E.L. et al. Effect of early luteolysis in progesterone-based timed AI protocols in Bos indicus, Bos indicus x Bos taurus, and Bos taurus heifers. Theriogenology, v. 69, p. 167-175, 2008.

CASTILHO, C.;GARCIA, J.M.; RENESTO, A. et al. Follicular dynamics and plasma FSH and progesterone concentrations during follicular deviation in the first post-ovulatory wave in Nelore (Bos indicus) heifers. Animal Reproduction Science, v. 98, p. 189-96, 2006.

COLAZO, M.G.; KASTELIC, J.P.; MARTÍNEZ, M.F. et al. Fertility following fixed-time AI in CIDR-treated beef heifers given GnRH or estradiol cypionate and fed diets supplemented with flax seed or sunflower seed. Theriogenology, v. 61, p. 1115-1124, 2004.

CONNOR, H.C.; HOUGHTON, P.L.; LEMENAGER, R.P. et al. Effect of dietary energy, body condition and calf removal on pituitary gonadotropins, gonadotropin-releasing hormone $(\mathrm{GnRH})$ and hypothalamic opioids in beef cows. Domestic Animal Endocrinology, v. 7, p. 403-411, 1990.

COOPER, D.A.; CARVER, D.A.; VILLENEUVE, P. et al. Effects of progestogen treatment on concentrations of prostaglandins and oxytocin in plasma from the posterior vena cava of postpartum beef cows. Journal of Reproduction and Fertility, v. 91, p. 411-421, 1991.

COPELIN, J.P.; SMITH, M.F.; KEISLER, D.H. et al. Effect of ative immunization of prepartum and post-partum cows against prostaglandin $\mathrm{F}_{2} \alpha$ on lifespan and progesterone secretion of short-lived corpora lutea. Journal Reproduction Fertility, v. 87, p. 199-207, 1989.

CROWE, M.A.; PADMANABHAN, V.; MIHM M. et al. Resumption of follicular waves in beef cows is not associated with periparturient changes in follicle-stimulating hormone heterogeneity despite major changes in steroid and luteinizing hormone concentrations. Biology of Reproduction, v. 58, p. 1445-1450, 1998.

CUNNINGHAM, J.G. Tratado de Fisiologia Veterinária. 2. ed. Rio de Janeiro: Guanabara Koogan, 1999, p. 353-375.

CUSTER, E.E., BERARDINELLI, B.G.; SHORT, R.E. et al. Postpartum interval of oestrus and patterns of LH and progesterone in first-calf suckled beef cows exposed to mature bulls. Journal of Animal Science, v. 68, p. 1370-1377, 1990.

DA SILVA, A.S.; COSTA E SILVA, E.V.; NOGUEIRA, E. Et al. Avaliação do custo/benefício da inseminação artificial convencional e em tempo fixo de fêmeas bovinas pluríparas de corte. Revista Brasileira de Reprodução Animal, v. 31, p. 443-455, 2007.

DRIANCOURT, M.A. Regulation of ovarian follicular dynamics in farm animals. Implications for manipulation of reproduction. Theriogenology, v. 55, p. 1211-1239, 2001.

DUFFY, P.; CROWE, M.A.; AUSTIN, E.J. et al. The effect of eCG or estradiol at or after norgestomet removal on follicular dynamics, estrus and ovulation in early post-partum beef cows nursing calves. Theriogenology, v. 61, p. 725-734, 2004. 
EGITO, A.A.; MARIANTE, A.S.; ALBUQUERQUE, M.S.M. Programa brasileiro de conservação e recursos genéticos. Archivos de Zootecnia, v. 51, p. 39-52, 2002.

EL-DIN ZAIN, A.; NAKAO, T.; RAOUF, M.A. et al. Factors in the resumption of ovarian activity and uterine involution in postpartum dairy cows. Animal Reproduction Science, v. 38, p. 203-214, 1995.

EUCLIDES FILHO, K. Contribution of European adapted breeds to beef production under tropical and subtropical enviroments. Conferência Global de Conservação Genética, p. 6, 2000.

EVANS, A.C.; FORTUNE, J.E. Selection of dominant follicle in cattle occurs in the abscence of differences in the expression of messenger ribonucleic acid for gonadotropin receptors. Endocrinology, v. 138, p. 2963-2971, 1997.

FERNANDEZ, D.L., BERARDINLLI, J.G.; SHORT, R.E. et al. Acute and chronic changes in luteinizing hormone secretion and postpartum interval to estrus in first-calf suckled beef cows exposed continuously or intermittently to mature bulls. Journal of Animal Science, v. 74, p. 1098-1103, 1996.

FIGUEIREDO, R.A.; BARROS, C.M.; PINHEIRO O.L. et al. Ovarian follicular dynamics in nelore breed cattle. Theriogenology, v. 47, p. 1489-1505, 1997.

FIKE, K.E.; DAY, M.L.; INSKEEP, E.K. et al. Estrus and luteal function in suckled beef cows that were anestrous when treated with an intravaginal device containing progesterone with or without a subsequent injection of estradiol benzoate. Journal of Animal Science, v. 75, p. 20092015, 1997.

FIORAVANTI, M.C.S.; SERENO, J.R.B.; NEIVA, A.C.G.R. et al. Reintrodução do gado Curraleiro na comunidade quilombola Kalunga de Cavalcante, Goiás, Brasil: resultados parciais. In: SIMPÓSIO NACIONAL DO CERRADO, 9., SIMPÓSIO INTERNACIONAL DE SAVANAS TROPICAIS, 2., 2008, Brasília. Anais eletrônicos... [CD ROM], Brasília: EMBRAPA, 2008.

FORTUNE, J.E.; RIVERA, G.M. Folículo dominante persistente em bovinos: aspectos básicos e aplicados. Arquivos da Faculdade de Veterinária UFRGS, v. 27, p. 22-34, 1999.

GEARY, T.W.; WHITTIER, J.C.; HALLFORD, D.M. et al. Calf removal improves conception rates to the Ovsynch and COSynch protocols. Journal of Animal Science, v. 79, p. 1-4, 2001.

GIBSON, J.P; BISHOP, S.C. Use of molecular markers to enhance resistence of livestock to disease: a global approach. Revue Scientifique et Technique International Office of Epizootics, v. 24, n. 1, p. 343-353, 2005.

GIMENES, L.U.; SÁ FILHO, M.F.; CARVALHO, N.A.T. et al. Follicle deviation and ovulatory capacity in Bos indicus capacity. Theriogenology, v. 69, p. 852-858, 2008. 
GINTHER, O.J.; KNOPF, L.; KASTELIC, J.P. Temporal associations among ovarian events in cattle during oestrous cycles with two and three follicular waves. Journal of Reproduction and Fertility, v. 87, p. 223-230, 1989.

GINTHER, O.J.; WILTBANK, M.C.; FRICKE, P.M. et al. Selection of the dominant follicle in cattle. Biology of Reproduction, v. 55, p. 1187-1194, 1996.

GINTHER, O.J.; BERGFELT, D.R.; BEG, M.A. et al. Follicle Selection in Cattle: Role of Luteinizing Hormone. Biology of Reproduction, v. 64, p. 197-205, 2001.

GONÇALVES, P.B.D; FIGUEIREDO, J.R.; FREITAS, V.J.F. Biotécnicas Aplicadas à Reprodução Animal. 2.ed. São Paulo: Roca Ltda, 2008, p. 33-56.

GRIFFITH, M.K.; WILLIAMS, G.L. Roles of maternal vision and olfaction in sucklingmediated inhibition of luteinizing hormone secretion, expression of maternal selectivity, and lactational performance of beef cows. Biology of Reproduction, v. 54, p. 761-768, 1996.

HAFEZ, E.S.E.; HAFEZ, B. Reprodução Animal. 7. ed. São Paulo: Manole Ltda, 2004, p. 3382.

HANLON, D.W.; WILLIAMSON, N.B.; WICHTEL, J.J. Ovulatory response and plasma luteinizing hormone concentrations in dairy heifers after treatment with exogenous progesterone and estradiol benzoate. Theriogenology, v. 47, p. 963-975, 1997.

HAUGHIAN, J.M.; GINTHER, O.J.; KOT, K. et al. Relationships between FSH patterns and follicular dynamics and the temporal associations among hormones in natural and GnRH-induced gonadotropin surges in heifers. Reproduction, v. 127, p. 23-33, 2004.

HURK, R.V.D.; ZHAO, J. Formation of mammalian oocytes and their growth, differentiation and maturation within ovarian follicles. Theriogenology, v. 63, p. 1717-1751, 2005.

Mariante, A.S.; Cavalcante, N. Animais do descobrimento: Raças domésticas da história do Brasil. Brasília, Embrapa Sede, 2000, 227 p.

IRELAND, J.J. Control of follicular growth and development. Journal of Reproduction and Fertility, v. 34, p. 39-54, 1987.

KRIEGSFELD, L.J.; MEI, D.F.; BENTLEY, G.E. et al. Identification and characterization of a gonadotropin-inhibitory system in the brains of mammals. Proceedings of the National Academy of Sciences, v. 103, p. 2410-2415, 2006.

LAMB, G.C.; LYNCH, J.M.; GRIEGER, D.M. et al. Ad libitum suckling by an unrelated calf in the presence or absence of a cow's own calf prolongs postpartum anovulation. Journal of Animal Science, v. 75, p. 2762-2769, 1997. 
LAMOGLIA, M.A.; SHORT, R.E.; BELLOWS, S.E. et al. Induced and synchronized estrus in cattle: dose titration of estradiol benzoate in peripubertal heifers and postpartum cows after treatment with an intravaginal progesterone-releasing insert and prostaglandin F2alpha. Journal of Animal Science, v. 76, p. 1662-1670, 1998.

LEUNG, S.T.; WATHES, D.C. Oestradiol regulation of oxytocin receptor expression in cyclic bovine endometrium. Reproduction, v. 119, p. 287-292, 2000.

LOGUÉRCIO, R.S. Regulação de receptores esteróides e dinâmica folicular em um sistema de indução hormonal pós-parto em vacas de corte. 2005. $80 \mathrm{f}$. Tese (Doutorado em Medicina Veterinária), Curso de Pós-Graduação em Medicina Veterinária, Universidade Federal de Santa Maria, Santa Maria, 2005.

LUCY, M.C.; STEVENSON, J.S. Gonadotropin-releasing hormone at estrus: luteinizing hormone, estradiol, and progesterone during the periestrual and postinsemination periods in dairy cattle. Biology of Reproduction, v. 35, p. 300-311, 1986.

MACIEL, M.N.; ZIEBA, D.A.; AMSTALDEN, M. et al. Leptin Prevents Fasting-Mediated Reductions in Pulsatile Secretion of Luteinizing Hormone and Enhances Its GonadotropinReleasing Hormone-Mediated Release en Heifers. Biology of Reproduction, v. 70, p. 229-235, 2004.

MAFFEI, M.; HALAAS, J.; RAVUSSIN, E. et al. Leptin levels in human and rodent: Measurement of plasma leptin and ob RNA in obese and weight-reduced subjects. Nature, v. 1, p. 1155-1161, 1995.

MALVEN, P.V.; PARFET, F.R.; GREGG, D.W. et al. Relationship among concentrations of four opioid neuropeptides and luteinizing hormone releasing hormone in neural tissue of beef cows following early weaning. Journal of Animal Science, v. 62, p. 723-733, 1986.

MANN, G.E.; LAMMING, G.E. The role of sub-optimal preovulatory oestradiol secretion in the etiology of premature luteolysis during the short oestrus cycle in cow. Animal Reproduction of Science, v. 64, p. 171-180, 2000.

MARIANTE, A.S.; CASTRO, S.T.R.; WETZEL, M.M.V. Conservation of animal genetic resources: structure of the Brazilian network. Conferência Global de Conservação Genética, p. $5,2000$.

MARIANTE, A.S.; CAVALCANTE, N. Animais do Descobrimento: raças domésticas da história do Brasil. Brasília: Embrapa Sede / Embrapa Recursos Genéticos e Biotecnologia, 2000. 232p.

MARIANTE, A.S.; DE BEM, A.R. Animal Genetic Resources Conservation Programme in Brazil. In: FAO. Animal Genetic Resources Information. Roma, 1992. 73p.

MARIANTE, A.S.; EGITO, A.A. Animal Genetic resources in Brazil: result of five centuries of natural selection. Theriogenology, v. 57, p. 223-235, 2002. 
MARTINEZ, M.F.; KASTELIC, J.P.; BO, G.A. et al. Effects of oestradiol and some of its esters on gonadotrophin release and ovarian follicular dynamics in CIDR-treated beef cattle. Animal Reproduction Science, v. 86, p. 37-52, 2005.

McKINNISS, E.N.; ESTERMAN, R.D.; WOODALL, S.A. et al. Evaluation of two progestogenbased estrous synchronization protocols in yearling heifers of Bos indicus $\times$ Bos taurus breeding. Theriogenology, v. 75, p. 1699-1707, 2011.

MEIDAN, R.; GIRSH, E.; BLUM, O. et al. In vitro differentiation of bovine theca and granulosa cells into small and large luteal-like cells: morphological and functional characteristics. Biology of Reproduction, v. 43, p. 913-921, 1990.

MENEGHETTI, M.; SÁ FILHO, O.G.; PERES, PERES, R.F.G. et al. Fixed-time artificial insemination with estradiol and progesterone for Bos indicus cows II: Strategies and factors affecting fertility. Theriogenology, v. 72, p. 210-218, 2009.

MIZUTA K. Estudo comparativo dos aspectos comportamentais do estro e dos teores plasmáticos de LH, FSH,progesterona e estradiol que precedem a ovulação em fêmeas bovinas Nelore (Bos taurus indicus), Angus (Bos taurus taurus) e Nelore $x$ Angus (Bos taurus indicus x Bos taurus taurus). 2003. 98 f. Tese (Doutorado), Faculdade de Medicina Veterinária e Zootecnia, Universidade de São Paulo, São Paulo, 2003.

MORAES, J.C.F.; DE SOUZA, C.J.H.; GONÇALVES, P.B.D. Controle do estro e ovulação em ruminantes. In: GONÇALVES, P.B.D.; FIGUEIREDO, J.R.; FREITAS, V.J.F. Biotécnicas aplicadas à reprodução animal. 2. ed. São Paulo: Roca, 2008, p. 33-56.

MOUNZIH, K.; LU, R.; CHEHAB, F.F. Leptin treatment rescues the sterility of genetically obese ob/ob males. Endocrinology, v. 138, p. 1190-1193, 1997.

MUJICA, F.; MENCHACA, M.A.; HAMMOND, A.C. et al. Comportamiento post destete de novillos Senepol, Hereford y Senepol x Hereford, en Brooksville, Florida. Archivos Latinoamericanos de Producción Animal, v. 5, p. 155-166, 1997.

NARDON, R.; RAZZOK, A.G.; MOURA, A.C. et al. Influência da raça, época de abate e metodologia de análise nas características quali-quantitativas de carcaças de bovinos selecionados para ganho de peso. In: REUNIÃO ANUAL DA SOCIEDADE BRASILEIRA DE ZOOTECNIA, 33., 1996, Fortaleza. Anais..., Fortaleza, 1996. v. 1, p. 200-202.

NEELY, D.P.; LIU, I.K.M.; HILLMAN, R.B. Equine Reproduction. New Jersey: Hoffmann-La Roche Inc, 1983, p. 24, 64.

NEHMI FILHO, V.A. Uma visão do futuro: a pecuária brasileira daqui a dez anos. In: ANUALPEC 2003: Anuário da Pecuária Brasileira. 9. ed. São Paulo: FNP Consultoria \& Comércio, 2003, p.14-30. 
NOGUEIRA, K.L. Certificação e qualidade de carnes. In: ANUALPEC 2003: Anuário da Pecuária Brasileira. 9. ed. São Paulo: FNP Consultoria \& Comércio, 2003 p. 44-45.

PASCHAL, J.C.; SANDERS, J.O; KERR, J.L. Calving and weaning characteristics of Angus-, Gray Brahman-, Gir-, Indu-Brazil-, Nellore-, and Red Brahman-sired F1 calves. Journal of Animal Science, v. 69, p. 2395-2402, 1991.

PENTEADO, L.; SÁ FILHO, M.F.; REZENDE, C.R.L. et al. Impacto da IATF na eficiência reprodutiva de vacas de corte. Acta Scientiae Veterinarie, v. 36, p. 605, 2008 (abstract).

PEREA, F.P.; ONDIZ, A.D.; PALOMARES, R.A. et al. Control of postpartum anestrous with an intra-vaginal progesterone device plus eCG or calf removal for $120 \mathrm{~h}$ in suckled crossbred cows managed in a pasture-based system. Animal Reproduction Science, v. 106, p. 298-310, 2008.

PERRY, R.C.; CORAH, L.R.; KIRACOFE, G.H. et al. Endocrine changes and ultrasonography of ovaries in suckled beef cows during resumption of postpartum estrous cycles. Journal of Animal Science, v. 69, p. 2548-2555, 1991.

PIMENTEL, C.A. Curso de Ginecologia Bovina, 2002, Tapes.

PINTO ANDRADE, L.; RHIND, S.M.; WRIGHT, I.A. et al. Effects of infusion of GnRH pulses and level of body condition on ovarian function in postpartum beef cows. Animal Reproduction Science, v. 40, p. 177-192, 1995.

PRIMO, A.T. El ganado bovino iberico en las americas: 500 años después. Archivos de Zootecnia, v. 41, p. 421-432, 1992.

PURSLEY, J.R.; MEE, O.M.; WILTBANK, M.C. Synchronization of ovulation in dairy cows using $\mathrm{PGF}_{2 \alpha}$ and GnRH. Theriogenology, v. 44, p. 915-23, 1995.

RAMIREZ-GODINEZ, J.A.; KIRACOFE, G.H.; CARNAHAN, D.L. et al. Evidence for ovulation and fertilization in beef cows with short estrous cycles. Theriogenology, v. 17, p. 409414, 1982.

RANGEL, P.N.; ZUCCHI, M.I.; FERREIRA, M.E. Similaridade entre raças bovinas brasileiras. Pesquisa Agropecuária Brasileira, v. 39, n. 1, p. 97-100, 2004.

RATHBONE, M.J.; KINDER, J.E.; FIKE, K. et al. Recent advances in bovine reproductive endocrinology and physiology and their impact on drug delivery system design for the control of the estrus cycle in cattle. Advance Drug Delivery Reviews, v. 50, p. 277-320, 2001.

REKWOT, P.I.; OGWU, D.; OYEDIPE, E.O. Influence of bull biostimulation, season and parity on resumption of ovarian activity of zebu (Bos indicus) cattle following parturition. Animal Reproduction Science, v. 63, p. 1-11, 2000. 
RICHARDS, M.W.; WETTEMANN, R.P.; SPICER, L.J. et al. Nutritional anestrus in beef cows: effects of body condition and ovariectomy on serum luteinizing hormone and insulin-like growth factor- I. Biology of Reproduction, v. 44, p. 961-966, 1991.

ROBERTS, R.M.; CROSS, J.C.; LEAMAN, D.W. Unique features of the trophoblast interferons. Pharmacology \& Therapeutics, v. 51, n. 3, p. 329-345 1991b.

RODRIGUES, C.A.; AYRES, H.; REIS, E.L. et al. Aumento da taxa de prenhez em vacas Nelore inseminadas em tempo fixo com uso de eCG em diferentes períodos pós-parto. In: XVIII REUNIÃO ANUAL DA SOCIEDADE BRASILEIRA DE TECNOLOGIA DE EMBRIÕES, 32. (Suplemento), 2004, Barra Bonita, SP. Anais... Barra Bonita, SBTE, 2004. p. 220.

RYAN, D.P.; SPOON, R.A.; GRIFFITH, M.K. et al. Ovarian follicular recruitment, granulosa cell steroidogenic potential and growth hormone/insulin-like growth factor-I relationships in suckled beef cows consuming high lipid diets: Effects of graded differences in body condition maintained during the puerperium. Domestic Animal Endocrinology, v. 11, p. 161-174, 1994. (Resumo)

SÁ FILHO, O.G.; THATCHER, W.W.; VASCONCELOS, J.L.M. Effect of progesterone and/or estradiol treatments prior to induction of ovulation on subsequent luteal lifespan in anestrous Nelore cows.Animal Reproduction Science, v. 112, p. 95-106, 2009a.

SÁ FILHO, O.G.; VILELA, E.R.; GEARY, T.W. et al. Strategies to improve fertility in postpartum multiparous Bos indicus cows submitted to a fixed-time insemination protocol with gonadotropin-releasing hormone and prostaglandin F2alpha. Journal of Animal Science, v. 87, p. 2806-2814, 2009b.

SÁ FILHO, M.F.; BALDRIGHI, J.M.; SALES, J.N.S. et al. Induction of follicular wave emergence and ovulation in progestin-based timed artificial insemination protocols for Bos indicus cattle. Animal Reproduction Science, v. 129, p. 132-139, 2011.

SÁ FILHO, M.F.; TORRES-JÚNIOR, J.R.S.; PENTEADO, L. et al. Equine chorionic gonadotropin improves the efficacy of a progestin-based fixed-time artificial insemination protocol in Nelore (Bos indicus) heifers. Animal reproduction science, v. 118, p. 182-187, 2010.

SÁ FILHO, M.F.; PENTEADO, L.; REIS, E.L. et al. Timed artificial insemination early in the breeding season improves the reproductive performance of suckled beef cows. Theriogenology, v. 79, p. 625-632, 2013.

SANTIN, A.P.I. Perfil sanitário de bovinos da raça Curraleiro frente a enfermidades de importância econômica. 2008. 78 f. Tese (Doutorado em Ciência Animal), Escola de Veterinária, Universidade Federal de Goiás, Goiânia, 2008.

SALES, J.N.S.; CARVALHO, J.B.P.; CREPALDI, G.A. et al. Effects of two estradiol esters (benzoate and cypionate) on the induction of synchronized ovulations in Bos indicus cows submitted to a timed artificial insemination protocol. Theriogenology, v. 78, p. 510-516, 2012. 
SALES, J.N.S.; CREPALDI, G.A.; GIROTTO, R.W. et al. Fixed-time AI protocols replacing eCG with a single dose of FSH were less effective in stimulating follicular growth, ovulation, and fertility in suckled-anestrus Nelore beef cows. Animal Reproduction Science, v. 124, p. 12-18, 2011.

SARTORI, R.; FRICKE, P.M.; FERREIRA, J.C.P. et al. Follicular Deviation and Acquisition of Ovulatory Capacity in Bovine Follicles. Biology of Reproduction, v. 65, p. 1403-1409, 2001.

SARTORI, R.; HAUGHIAN, J.; SHAVER, R. et al. Função ovarian e concentrações séricas de hormônios esteróides no ciclo estral de novilhas e vacas lactantes da raça Holandesa. Journal of Dairy Science, v. 87, p. 905-920, 2004.

SENGER, P.L. Pathways to Pregnancy and Parturiation. 2. ed. Washington: Current Conceptions Inc, 2003, p. 199-203, 312-314.

SEGERSON, E.C.; HANSEN, T.R.; LIBBY, D.W. et al. Ovarian and Uterine Morphology and Function in Angus and Brahman Cows. Journal of Animal Science, v. 59, p. 1026-1046, 1984.

SERRANO, G.M.; EGITO, A.A.; McMANUS, C. et al. Genetic diversity and population structure of Brazilian native bovine breeds. Pesquisa Agropecuária Brasileira, v. 39, p. 543549, 2004.

SILVEIRA, P.A.; SPOON, R.A.; RYAN D.P. et al. Evidence for maternal behavior as a requisite link in suckling-mediated anovulation in cows. Biology of Reproduction, v. 49, p. 1338-1346, 1993.

SIQUEIRA, L.C.; OLIVEIRA, J.F.; ROVANI, M.T. et al. Effects of estradiol and progestins on follicular regression before, during, and after follicular deviation in postpartum beef cows. Theriogenology, v. 71, p. 614-619, 2009.

SHORT, R.E.; BELLOWS, R.A.; STAIGMILLER, R.B. et al. Phisiological mechanisms controlling anestrous and infertility in postpartum beef cattle. Journal of Animal Science, v. 68, p. 799-816, 1990.

SOUZA, A.H.; VIECHNIESKI, S.; LIMA, F.A. et al. Effects of equine chorionic gonadotropin and type of ovulatory stimulus in a timed-AI protocol on reproductive responses in dairy cows. Theriogenology, v. 72, p.10-21, 2009.

SPINOSA, H.S.; GÓRNIAK, S.L.; BERNARDI, M.M. Farmacologia Aplicada à Medicina Veterinária. 3. ed. Rio de Janeiro: Guanabara Koogan, 2002, p. 15-19; 301-332.

STRAUCH, T.A.; NEUENDORFF, D.A.; BROWN, C.G. et al. Effects of lasalocid on circulating concentrations of leptin and insulin-like growth factor-I and reproductive performance of postpartum Brahman cows. Journal of Animal Science, v. 81, p. 1363-1370, 2003. 
TORRES-JÚNIOR, J.R.S.; MELO, W.O.; ELIAS, A.K.S. et al. Considerações técnicas e econômicas sobre reprodução assistida em gado de corte. Revista Brasileira de Reprodução Animal, v. 33, p. 53-58, 2009.

TORTORELLA, R.D.; FERREIRA, R.; DOS SANTOS, J.T. et al. The effect of equine chorionic gonadotropin on follicular size, luteal volume, circulating progesterone concentrations, and pregnancy rates in anestrous beef cows treated with a novel fixed-time artificial insemination protocol. Theriogenology, v. 79, p. 1204-1209, 2013.

TROXEL, T.R.; CRUZ, L.C.; OTT, R.S. et al. Norgestomet and gonadotropin-releasing hormone enhance corpos luteum function and fertility of postpartum suckled beef cows. Journal of Animal Science, v. 71, p. 2579-2585, 1993.

VASCONCELOS, J.L.M. ; SÁ FILHO, O.G. ; PEREZ, G.C. et al. Intravaginal progesterone device and/or temporary weaning on reproductive performance of anestrous crossbred Angus $\times$ Nelore cows. Animal Reproduction Science, v. 111, p. 302-311, 2009.

VELLOSO, L. Evolução e tendências da pecuária bovina de corte no Brasil, Produção de novilho de corte In: SIMPOSIO SOBRE PECUÁRIA DE CORTE, 4., 1996, Piracicaba, Anais..., Piracicaba, FEALQ, 1996. p. 1-40.

VIEIRA, A.; LOBATO, J.F.P.; JUNIOR, R.A.A.T. et al. Fatores Determinantes do Desempenho Reprodutivo de Vacas Nelore na Região dos Cerrados do Brasil Central. Revista Brasileira de Zootecnia, v. 34, n.6, p. 2408-2416, 2005.

WEBB, R.; GARNSWORTHY, P.C.; CAMPBELL, B.K. et al. Intra-ovarian regulation of follicular development and oocyte competence in farm animals. Theriogenology, v. 68, p. S22S29, 2007.

WERTH, L.A.; WHITTIER, J.C.; AZZAM, S.M. et al. Relationship between circulating progesterone and conception at the first postpartum estrus in young primiparous beef cows. Journal of Animal Science, v. 74, p. 616-619, 1996.

WILDMAN, E.E.; JONES, G.M.; WAGNER, P.E. A dairy cow body condition scoring system and its relationship to selected production characteristics. Journal of Dairy Science, v. 65, p. 495-501, 1982.

WILLIAMS, G.L.; AMSTALDEN, M.; GARCIA, M.R. et al. Leptin and its role in the central regulation of reproduction in cattle. Domestic Animal Endocrinology, v. 23, p. 339-349, 2002.

WOLFE, M.W.; STUMPF, T.T.; ROBERSON, M.S. et al. Opioid and 17[beta]-estradiol regulation of LH and FSH secretion during sexual maturation in heifers. Domestic Animal Endocrinology, v. 8, p. 491-498, 1991.

WOLFENSON, D.; INBAR, G.; ROTH, Z. et al. Follicular dynamics and concentrations of steroids and gonadotropins in lactating cows and nulliparous heifers. Theriogenology, v. 62, p. 1042-1055, 2004. 
YAVAS, Y.; WALTON, J.S. Postpartum acyclicity in suckled beef cows: A review. Theriogenology, v. 54, p. 25-55, 2000a.

YAVAS, Y.; WALTON, J.S. Induction of ovulation in postpartum suckled beef cows: a review. Theriogenology, v. 54, p. 1-23, 2000 b.

ZIEBA, D.A.; AMSTALDEN, M.; MORTON, S. et al. Regulatory roles of leptin at the hypothalamic-hypophyseal axis before and after sexual maturation in cattle. Biology of Reproduction, v. 71, p. 804-812, 2004.

ZOLLERS, W.G.; GARVERICK, H.A.; SMITH M.F. et al. Concentrations of progesterone and oxytocin receptors in endometrium of postpartum cows expected to have a short or normal oestrous cycle. Reproduction, v. 97, p. 329-337, 1993. 


\section{CAPÍTULO 2}

\section{DINÂMICA FOLICULAR OVARIANA DURANTE O CICLO ESTRAL EM VACAS LOCALMENTE ADAPTADAS DA RAÇA CURRALEIRO PÉ-DURO}

Rodrigo Dorneles Tortorella ${ }^{\mathrm{a}, \mathrm{c}}$, Mairon Rocha Modesto ${ }^{\mathrm{b}}$, Priscilla Passoni Silva ${ }^{\mathrm{c}}$, Joseane Padilha da Silva ${ }^{\mathrm{c}}$, Jairo Pereira Neves ${ }^{\mathrm{a}}$, Alexandre Floriani Ramos ${ }^{\mathrm{c}}$

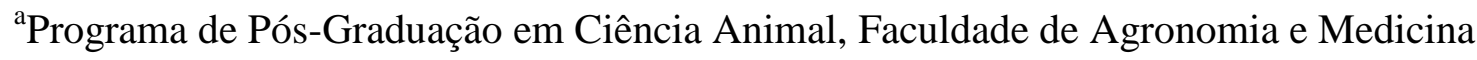
Veterinária, Universidade de Brasília, UnB, Brasília, Distrito Federal, Brasil;

${ }^{\mathrm{b}}$ Faculdades Integradas da União Educacional do Planalto Central, FACIPLAC, Brasília, Distrito Federal, Brasil;

${ }^{c}$ Embrapa Recursos Genéticos e Biotecnologia, Brasília, Distrito Federal, Brasil; 


\section{RESUMO}

O objetivo do trabalho foi caracterizar e comparar a dinâmica folicular de novilhas e vacas Curraleiras Pé-Duro criadas em um ambiente de clima tropical seco. Novilhas $(\mathrm{n}=12)$ e vacas (n = 11) não lactantes e cíclicas foram examinadas diariamente (avaliação ultrassonográfica) durante o intervalo entre duas ovulações (um ciclo estral). O tamanho e posição de folículos maiores que $3 \mathrm{~mm}$ e do corpo lúteo (CL) foram registrados. Não houve diferença na dinâmica folicular entre novilhas e vacas. Desta forma, os dados foram unificados de acordo com o número de ondas foliculares. As fêmeas apresentaram em sua maioria dois padrões de ondas foliculares, duas $(36,8 \%)$ e três $(63,2 \%)$, não havendo diferença na duração do ciclo estral entre estes. Nos animais com três ondas, a fase de dominância (dias), taxa de crescimento $(\mathrm{mm} / \mathrm{d})$ e máximo diâmetro $(\mathrm{mm})$ do segundo folículo dominante (FD) foram menores em relação aos outros. Assim como, o número de folículos nesta onda foi menor em relação às outras. Nos animais com três ondas, a taxa de crescimento $(1,2 \pm 0,1 \mathrm{~mm} / \mathrm{d}$ vs $0,8 \pm 0,1 \mathrm{~mm} / \mathrm{d})$ e máximo diâmetro do folículo ovulatório (FO; 13,1 $\pm 0,3 \mathrm{~mm}$ vs 12,1 $\pm 0,2 \mathrm{~mm}$ ) foram maiores em relação aos com duas ondas, respectivamente. Independentemente do padrão de ondas, a duração do FO foi menor do que do FD não ovulatório das outras ondas. O desenvolvimento do CL não diferiu entre os animais com duas e três ondas. Foram encontradas diferenças na dinâmica folicular de animais com duas e três ondas, sendo algumas características foliculares semelhantes a animais Bos taurus e outras a Bos indicus, possivelmente pela introgressão de genes zebuínos na raça. Os resultados poderão ser utilizados para a melhor manipulação do ciclo estral contribuindo para a obtenção de bons resultados na inseminação artificial, inseminação artificial em tempo fixo e na múltipla ovulação e transferência de embriões. 
Palavras-chave: conservação; corpo lúteo; folículo subordinado; folículo dominante; recursos genéticos. 


\section{ABSTRACT}

The aim of the present study was to characterize ovarian follicular dynamics in locally adapted Curraleiro Pé-Duro cows and heifers. Cyclic heifers $(n=12)$ and non-lactating, multiparous cows ( $n=11$ ) were examined daily by ultrasonography for two consecutive ovulations (an estrous cycle). Follicles > $3 \mathrm{~mm}$ and corpus luteum (CL) were measured and followed until they disappeared. Follicular and luteal characteristics were not different between heifers and cows. Consequently, data on cows and heifers were combined according to the number of follicular waves. Follicular dynamics was characterized by the predominance of two (36.8\%) and three (63.2\%) follicular waves. No difference in estrous cycle length between these follicular wave patterns was observed. In animals showing three waves, dominance phase (days), growth rate $(\mathrm{mm} / \mathrm{d})$ and maximum diameter of second dominant follicle $(\mathrm{DF})$ was smaller $(\mathrm{P} \leq 0.05)$ than other DFs. Also, the number of recruited follicles was smaller in the second follicular wave. The ovulatory follicle $(\mathrm{OF})$ growth rate $(1.2 \pm 0.1 \mathrm{~mm} / \mathrm{d}$ vs $0.8 \pm 0.1 \mathrm{~mm} / \mathrm{d})$ and maximum diameter $(13.1 \pm 0.3 \mathrm{~mm}$ vs $12.1 \pm 0.2 \mathrm{~mm})$ were greater $(\mathrm{P} \leq 0.05)$ in females showing three waves respectively. The ovulatory wave was shorter $(\mathrm{P} \leq 0.05)$ than the preceding waves regardless of the wave pattern. No difference was found in CL development between females with two and three follicular wave patterns. Some follicular dynamics characteristics were similar to Bos taurus and others to Bos indicus confirming the crosses made throughout the years. Data from this study will be useful to a better estrous cycle manipulation aiming good results in artificial insemination (AI), fixed-time AI (FTAI) and multiple ovulation and embryo transfer (MOET) programs. 
Key-words: conservation; corpus luteum; dominant follicle; genetic resources; subordinate follicle. 


\section{INTRODUÇÃO}

A raça localmente adaptada Curraleiro Pé-Duro, tem origem na raça Mirandesa trazida pelos colonizadores portugueses e espanhóis para a América Latina, há mais de 500 anos (Primo, 1992). No Brasil, sua criação foi estabelecida em áreas com baixa qualidade de pastagem, umidade e altas temperaturas (Nordeste e Centro-Oeste), resultando em animais rústicos e resistentes a condições desfavoráveis (Serrano et al., 2004; Bianchini et al., 2006).

O cenário do mercado econômico futuro aponta que o consumidor cada vez mais será exigente quanto à carne ingerida, e que a utilização de produtos químicos (antibióticos, antiparasitários) será a mínima possível. Desta forma, características observadas no Curraleiro Pé-Duro como, a maior resistência a doenças em geral, ectoparasitas, endoparasitas e intoxicações (Egito et al., 2002; Mariante \& Egito, 2002) tornam-se grandes atrativos, tornandose uma alternativa de produção com menor investimento (Neiva et al., 2011). Entretanto, devido à intensa pressão de seleção genética realizada nas raças exóticas Bos taurus e Bos indicus e cruzamentos desordenados destas com o Curraleiro Pé-Duro, sua população teve uma queda para em torno de 5.000 animais (Fioravanti et al., 2011).

A preservação e expansão da raça passam pela utilização de biotecnologias da reprodução como a inseminação artificial em tempo fixo (IATF) e a múltipla ovulação e transferência de embriões (MOTE), por exemplo. Contudo, para o sucesso na IATF e/ou MOTE é necessário o conhecimento da fisiologia reprodutiva da raça como, por exemplo, o padrão do número de ondas foliculares, número de folículos recrutados na emergência, tamanho de folículo dominante (FD) e duração do ciclo estral, ainda desconhecido para esse tipo de animal. Nas raças taurinas (Ginther et al., 1989; Sirois \& Fortune, 1988; Sartoti et al., 2001; Alves et al., 2002) e 
zebuínas (Figueiredo et al., 1997; Alvarez et al., 2000; Castilho et al., 2007 Coutinho et al., 2007) selecionadas geneticamente pelo homem, vários estudos sobre a dinâmica folicular foram realizados, conduzindo a uma boa manipulação hormonal e aumento dos índices reprodutivos (Baruselli et al., 2006; Bó et al., 2006; Sá Filho et al., 2013). Entretanto, existem diferenças fisiológicas entre estas duas linhagens sanguíneas selecionadas pelo homem (Baruselli et al., 2007), sendo possível que o Curraleiro Pé-Duro, selecionado "naturalmente", possa ter também particularidades reprodutivas.

O objetivo do presente trabalho foi caracterizar e comparar a dinâmica folicular de novilhas e vacas Curraleiras Pé-Duro criadas em um ambiente de clima tropical seco. 


\section{MATERIAIS E MÉTODOS}

\subsection{Local, Manejo Alimentar e Animais}

O experimento foi realizado durante os meses de fevereiro e março na Fazenda

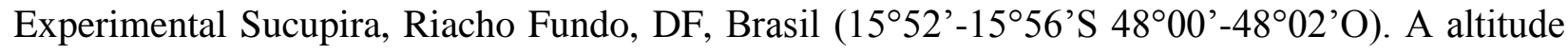
no local varia de 1050 a 1250 metros, sendo o clima predominante o Koppen Aw, indicando inverno seco (umidade relativa pode chegar a 10\%) e verão chuvoso.

Foram utilizadas 11 vacas pluríparas, não lactantes, entre três e oito anos, e 11 novilhas com dois anos, com condição corporal média 3 (1- muito magra e 5- muito gorda; Wildman et al., 1982). Os animais foram mantidos durante todo experimento em pastagem de Brachiaria decumbens, com suplementação mineral e acesso a água ad libitum.

Todos os procedimentos descritos no trabalho foram aprovados pelo Comitê de Ética e Bem Estar Animal da Embrapa Recursos Genéticos e Biotecnologia, protocolo CEUA $02 / 2013$.

\subsection{Sincronização da ovulação e avaliação ultrassonográfica}

Previamente ao Experimento, todos os animais foram submetidos a exame ginecológico que constava de palpação retal, avaliação ultrassonográfica (Mindray 2200 Vet, 
Shenzhen, China; equipado com probe transrectal de 7,5 MHz) e vaginoscopia, para determinar a ocorrência ou não de doenças ou anormalidades no trato reprodutivo.

O estro foi sincronizado com duas aplicações de D-Cloprostenol intramuscular (IM; 0,150 mg PGF $2 \alpha$; Prolise ${ }^{\circledR}$, Tecnopec LTDA, São Paulo, Brazil) administradas com o intervalo de 11 dias. A partir do dia seguinte a segunda aplicação de $\mathrm{PGF}_{2 \alpha}$ os animais foram observados quanto à manifestação de estro duas vezes ao dia com intervalo de 12 horas, por um período de 30 minutos com auxílio de rufião. O momento do estro foi determinado quando uma fêmea permitiu a monta pelo rufião ou por outra fêmea (Galina \& Orihuela, 2007).

No dia seguinte da segunda aplicação de $\mathrm{PGF}_{2 \alpha}$ também foi iniciada a avaliação ovariana ultrassonográfica (Mindray 2200 Vet, Shenzhen, China; equipado com probe transretal de 7,5 MHz), a cada 24 horas (08:00 h as 10:00 h da manhã), até dois dias após a segunda ovulação consecutiva. A duração do ciclo estral foi caracterizada pelo período entre duas ovulações. Cada folículo maior de $3 \mathrm{~mm}$ e o corpo lúteo (CL) foram monitorados diariamente e desenhados em uma ficha de dinâmica folicular, caracterizando o tamanho e localização no respectivo ovário. O diâmetro folicular foi determinado pela média de dois diâmetros perpendiculares entre eles. O dia da ovulação (Dia 0) foi determinado após a identificação do estro, e desaparecimento abrupto do FD ( $\geq 10 \mathrm{~mm})$ entre dois exames consecutivos com formação subsequente de um CL. A mensuração do volume (V) do CL foi feita após identificação dos diâmetros perpendiculares ( $\mathrm{Da}$ e $\mathrm{Db}$ ) do mesmo. O volume foi calculado pela fórmula $\mathrm{V}=4 / 3 \times \pi \times \mathrm{R}^{3}$, onde $\mathrm{R}=(\mathrm{Da} / 2+\mathrm{Db} / 2) / 2$. Os corpos lúteos cavitários foram mensurados subtraindo-se o volume da cavidade com líquido do volume total. A duração do CL foi caracterizada pela primeira identificação ao redor de dois dias após ovulação até sua última visualização anterior a ovulação seguinte.

A onda folicular foi caracterizada pelo crescimento inicial de um grupo de folículos, em torno de $4 \mathrm{~mm}$, em que após alguns dias, um obteve maior dimensão (FD) em relação aos outros, que começaram a diminuir de tamanho. O dia da emergência folicular foi determinado pelo dia em que o futuro FD ( $\geq 10 \mathrm{~mm})$ da respectiva onda folicular tinha em torno de $4 \mathrm{~mm}$, em análise retrospectiva. O FD foi definido como o maior folículo que cresceu até em torno de $10 \mathrm{~mm}$ ou mais, e que era pelo menos $2 \mathrm{~mm}$ maior que o maior folículo subordinado (FS). Foi considerado folículo ovulatório (FO) o último folículo dominante, independentemente do número de ondas, que veio a ovular. A duração do FD e maior FS compreendeu desde sua 
primeira identificação na emergência até completa atresia ou ovulação no caso do FO. A fase de dominância (dias) do FD foi caracterizada pelo período de crescimento e manutenção do diâmetro. A taxa de crescimento folicular $(\mathrm{mm} / \mathrm{d})$ do FD e maior FS foi calculada pela razão entre a variação observada no diâmetro folicular e o número de dias de observação.

\subsection{Análise estatística}

As análises dos dados foram realizadas com o auxílio do software estatístico gratuito R Core Team 2013 (R: A language and environment for statistical computing. R Foundation for Statistical Computing, Vienna, Austria) adotando-se como nível de significância $\mathrm{P} \leq 0,05$. Inicialmente o modelo estatístico teve como efeito principal de grupo a categoria animal (vaca vs novilha). Contudo, após comparação das médias das características foliculares pelo método de Bootstrap verificou-se a grande semelhança entre os grupos. Desta forma optou-se por unir o banco de dados e comparou-se o efeito médio das características foliculares de acordo com o número de ondas (2 vs 3). Os ajustes das curvas de desenvolvimento folicular e luteal foram realizados pelo modelo de regressão linear (método dos mínimos quadrados), sendo a variável resposta o tamanho do FD e volume do CL, respectivamente, e a covariável os dias de avaliação. Para avaliar a qualidade do ajuste da curva, utilizou-se como critério o coeficiente de determinação $\left(\mathrm{R}^{2}\right)$, bem como a análise gráfica dos resíduos. A comparação de médias entre os grupos com 2 e 3 ondas para as diversas características foliculares e luteais foi realizada pelo método Bootstrap. Este método foi escolhido devido ao tamanho da amostra disponível não ser suficientemente grande para garantir os pressupostos necessários para aplicação dos testes clássicos de comparações de médias. Os dados foram apresentados como média \pm erro padrão da média (EPM). 


\section{RESULTADOS}

Das 11 vacas avaliadas uma foi excluída da análise por não ter sido observada ovulação subsequente após 55 dias da primeira. Quanto às novilhas $(\mathrm{n}=11)$, duas foram excluídas da análise estatística, sendo uma por ter demonstrado quatro ondas foliculares e uma por ter tido intervalo entre ovulações atípico (14 dias).

As novilhas $(\mathrm{n}=9)$ e vacas $(\mathrm{n}=10)$ demonstraram basicamente dois padrões de ondas foliculares: duas ondas $(33,33 \%, \mathrm{n}=3 ; 40 \%, \mathrm{n}=4)$ e três ondas $(66,67 \%, \mathrm{n}=$ 6; $60 \%, \mathrm{n}=6$ ), respectivamente. Comparando-se vacas e novilhas com o mesmo padrão folicular de ondas, pela análise de regressão e comparação de médias (Bootstrap), não foram observadas diferenças $(\mathrm{P}>0,05)$ nas características foliculares e luteais. Consequentemente, optou-se por unificar os dados e comparou-se o desenvolvimento folicular e luteal entre animais com duas $(2 \mathrm{O}, 36,8 \% ; \mathrm{n}=7)$ versus três $(3 \mathrm{O}, 63,2 \% ; \mathrm{n}=12)$ ondas foliculares. O padrão do comportamento do FD nos animais com duas ondas $(2 \mathrm{O})$ e três ondas $(3 \mathrm{O})$, pode ser verificado nas Figuras 2.1 e 2.2. 

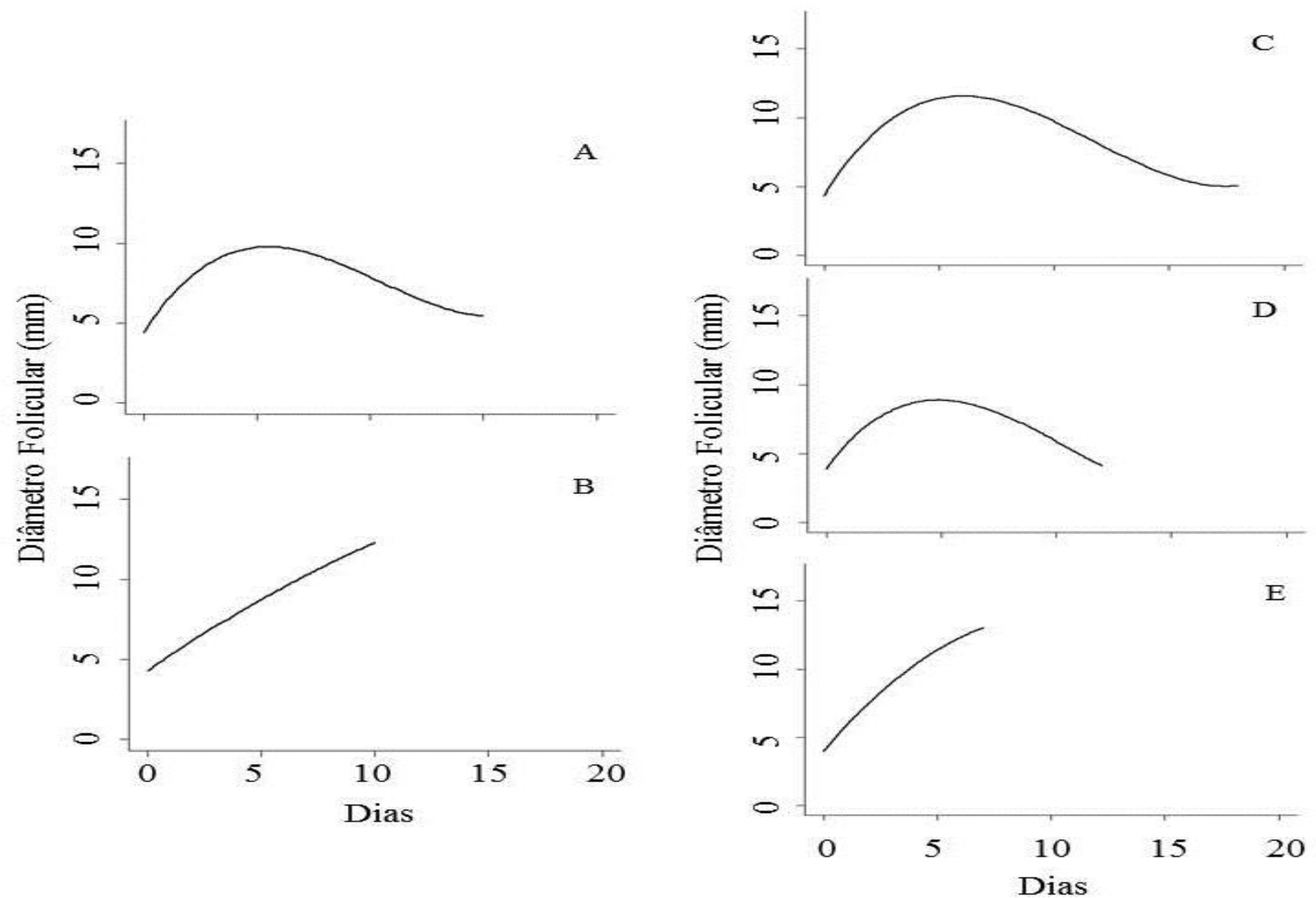

Figura 2.1. Equação de regressão do padrão de comportamento do desenvolvimento do $1^{\circ}$ e $2^{\circ}$ folículo dominante (FD) nos animais do grupo $2 \mathrm{O}, \mathrm{A}$ e $\mathrm{B}$, respectivamente e do $1^{\circ}, 2^{\circ}$ e $3^{\circ} \mathrm{FD}$ nos animais do grupo $3 \mathrm{O}, \mathrm{C}, \mathrm{D}$ e $\mathrm{E}$, respectivamente. $A=4,383041+2,241644 x-0,277616 x^{2}+0,0088 x^{3}, R^{2}=0,51 ; B=4,27146+0,98906 x-$ $0,01846 x^{2}, R^{2}=0,89 ; C=4,325581+2,731449 x-0,305909 x^{2}+0,008688 x^{3}, R^{2}=0,58 ; D=3,87059+2,31368 x$ $-0,31202 x^{2}+0,01007 x^{3}, R^{2}=0,67 ; E=3,95774+1,98322 x-0,09814 x^{2}, R^{2}=0,91$, em que $Y=$ tamanho do FD $\mathrm{e} \mathrm{x}=$ dia da mensuração. As ondas foram normalizadas para o dia 0 , independentemente de ser a $1^{\mathrm{a}}, 2^{\mathrm{a}}$ ou $3^{\mathrm{a}}$. 


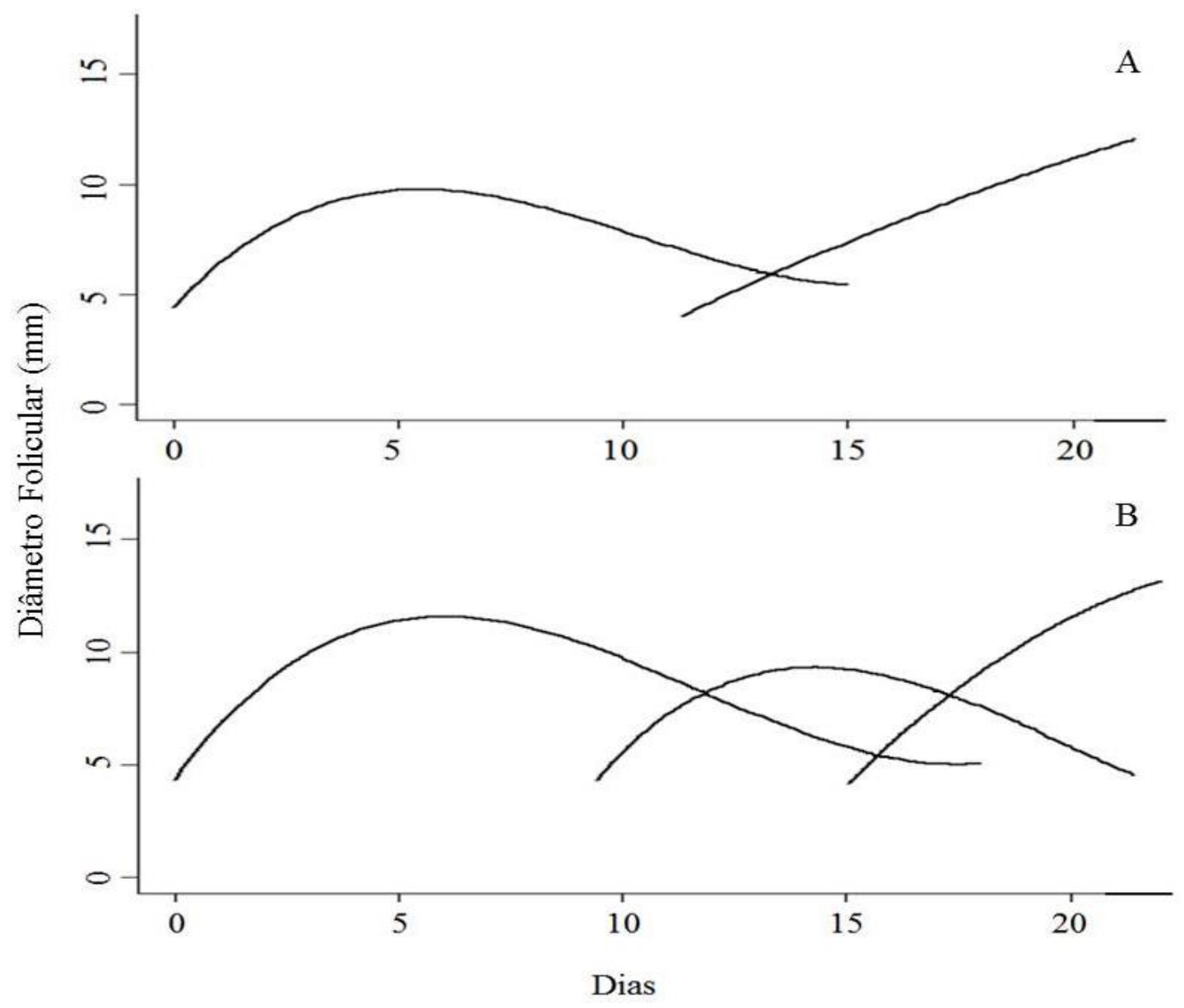

Figura 2.2. Exemplo do padrão de crescimento do folículo dominante (FD) nos animais com duas (A) e três ondas (B) foliculares na raça Curraleiro Pé-Duro.

\subsection{Dinâmica folicular}

As características do ciclo estral, FD e maior FS em cada onda folicular dos grupos $2 \mathrm{O}$ e $3 \mathrm{O}$, podem ser observados nas Tabelas 2.1 e 2.2. 
Tabela 2.1. Características do desenvolvimento folicular e folículos dominantes (FD; média \pm EPM) dos padrões 2 e 3 ondas foliculares nas fêmeas Curraleiras Pé-Duro.

\begin{tabular}{|c|c|c|}
\hline \multirow[b]{2}{*}{ Parâmetros } & \multicolumn{2}{|c|}{ Grupos } \\
\hline & 2 ondas $(n=7)$ & 3 ondas $(n=12)$ \\
\hline Intervalo entre ovulações (dias) & $21,4 \pm 0,4$ & $22,3 \pm 0,6$ \\
\hline Intervalo estro-ovulação (horas) & $24,8 \pm 3,0$ & $26 \pm 2,0$ \\
\hline Dia emergência da $1^{a}$ onda* & $0,4 \pm 0,3$ & $0,2 \pm 0,1$ \\
\hline Dia emergência da $2^{\mathrm{a}}$ onda* & $11,1^{\mathrm{a}} \pm 0,4$ & $9,1^{b} \pm 0,6$ \\
\hline Dia emergência da $3^{a}$ onda* & - & $15,1 \pm 0,6$ \\
\hline Número de folículos recrutados na $1^{\mathrm{a}}$ onda & $10,8 \pm 1,3$ & $12,3^{A} \pm 0,9$ \\
\hline Número de folículos recrutados na $2^{\mathrm{a}}$ onda & $10 \pm 1,8$ & $8,4^{\mathrm{B}} \pm 0,9$ \\
\hline Número de folículos recrutados na $3^{\mathrm{a}}$ onda & - & $14,1^{A} \pm 1,3$ \\
\hline Duração do $1^{\circ} \mathrm{FD}$ (dias) & $14,2^{\mathrm{A}} \pm 1,1$ & $15,3^{\mathrm{A}} \pm 0,8$ \\
\hline Duração do $2^{\circ} \mathrm{FD}$ (dias) & $10^{\mathrm{b}, \mathrm{B}, 1} \pm 0,3$ & $11,4^{\mathrm{a}, \mathrm{B}} \pm 0,5$ \\
\hline Duração do $3^{\circ} \mathrm{FD}$ (dias) & - & $7,2^{\mathrm{C}, 2} \pm 0,2$ \\
\hline Fase de dominância do $1^{\circ} \mathrm{FD}$ (dias) & $8,7 \pm 0,6$ & $9,3^{A} \pm 0,5$ \\
\hline Fase de dominância do $2^{\circ} \mathrm{FD}$ (dias) & $10^{\mathrm{a}, 1} \pm 0,3$ & $7^{\mathrm{b}, \mathrm{B}} \pm 0,5$ \\
\hline Fase de dominância do $3^{\circ} \mathrm{FD}$ (dias) & - & $7,2^{\mathrm{B}, 2} \pm 0,2$ \\
\hline Fase de regressão $1^{\circ} \mathrm{FD}$ (dias) & $5,5 \pm 0,64$ & $5,9 \pm 0,5$ \\
\hline Fase de regressão $2^{\circ} \mathrm{FD}$ (dias) & - & $4,5 \pm 0,4$ \\
\hline Taxa de crescimento do $1^{\circ} \mathrm{FD}(\mathrm{mm} / \mathrm{d})$ & $1 \pm 0,1$ & $1^{\mathrm{B}} \pm 0,1$ \\
\hline Taxa de crescimento do $2^{\circ} \mathrm{FD}(\mathrm{mm} / \mathrm{d})$ & $0,8^{2} \pm 0,1$ & $0,9^{\mathrm{B}} \pm 0,1$ \\
\hline Taxa de crescimento do $3^{\circ} \mathrm{FD}(\mathrm{mm} / \mathrm{d})$ & - & $1,2^{\mathrm{A}, 1} \pm 0,1$ \\
\hline Máximo Diâmetro do $1^{\circ} \mathrm{FD}(\mathrm{mm})$ & $10,6^{\mathrm{b}, \mathrm{A}} \pm 0,3$ & $12,5^{\mathrm{a}, \mathrm{A}} \pm 0,4$ \\
\hline Máximo Diâmetro do $2^{\circ} \mathrm{FD}(\mathrm{mm})$ & $12,1^{\mathrm{a}, \mathrm{B}, 2} \pm 0,2$ & $9,9^{\mathrm{b}, \mathrm{B}} \pm 0,2$ \\
\hline Máximo Diâmetro do $3^{\circ} \mathrm{FD}(\mathrm{mm})$ & - & $13,1^{\mathrm{A}, 1} \pm 0,3$ \\
\hline Dia do Máximo Diâmetro do $1^{\circ} \mathrm{FD}^{*}$ & $5,8 \pm 0,9$ & $6,5 \pm 0,5$ \\
\hline Dia do Máximo Diâmetro do $2^{\circ} \mathrm{FD}^{*}$ & $20^{\mathrm{a}} \pm 0,5$ & $14,4^{b} \pm 0,8$ \\
\hline Dia do Máximo Diâmetro do $3^{\circ} \mathrm{FD}^{*}$ & - & $21,5 \pm 0,6$ \\
\hline
\end{tabular}

Entre os animais com $2 \mathrm{O}$ versus $3 \mathrm{O}$ houve diferença $(\mathrm{P} \leq 0,05)$ nos seguintes parâmetros (Tabela 1): (1) o dia da emergência da $2^{\mathrm{a}}$ onda foi precoce no grupo 3O; (2) duração do $2^{\circ}$ FD foi menor no 3O; (3) a duração do FO foi menor no 3O; (4) a fase de dominância do $2^{\circ}$ FD no 30 foi menor; (5) a fase de dominância do FO foi menor no 3O; (6) o máximo diâmetro do $1^{\circ}$ FD foi maior no 3O; (7) o máximo diâmetro do $2^{\circ} \mathrm{FD}$ foi menor no 3O; (8) o máximo diâmetro do FO foi maior no 3O; (9) e o dia do máximo diâmetro do $2^{\circ} \mathrm{FD}$ foi precoce no $3 \mathrm{O}$.

Dentro do grupo $2 \mathrm{O}$ houve diferença $(\mathrm{P} \leq 0,05)$ entre os seguintes parâmetros: (1) a duração do $2^{\circ} \mathrm{FD}$ foi menor; (2) e o máximo diâmetro do $2^{\circ} \mathrm{FD}$ foi maior. Já na comparação de médias entre as ondas foliculares do grupo 3O, (1) o número de folículos recrutados na segunda 
onda foi menor que na primeira e terceira ondas; (2) a duração do $1^{\circ} \mathrm{FD}$ foi maior que a do $2^{\circ} \mathrm{FD}$ e $3^{\circ} \mathrm{FD}$, sendo ainda a duração do $2^{\circ} \mathrm{FD}$ maior que a do $3^{\circ} \mathrm{FD}$; (3) a fase de dominância do $1^{\circ}$ FD foi maior em relação a segunda e terceira ondas; (4) o máximo diâmetro do $2^{\circ} \mathrm{FD}$ foi menor que o do $1^{\circ} \mathrm{FD}$ e $3^{\circ} \mathrm{FD}$; e (5) a taxa de crescimento do $3^{\circ} \mathrm{FD}$ foi maior que a do $1^{\circ} \mathrm{FD}$ e $2^{\circ} \mathrm{FD}$.

Tabela 2.2. Características do maior folículo subordinado (FS; média \pm EPM) nos padrões 2 e 3 ondas foliculares nas fêmeas Curraleiras Pé-Duro.

\begin{tabular}{|c|c|c|}
\hline \multirow[b]{2}{*}{ Parâmetros } & \multicolumn{2}{|c|}{ Grupos } \\
\hline & 2 ondas $(n=7)$ & 3 ondas $(n=12)$ \\
\hline Duração do $1^{\circ} \mathrm{FS}$ (dias) & $7,1 \pm 1$ & $6,8 \pm 0,6$ \\
\hline Duração do $2^{\circ} \mathrm{FS}$ (dias) & $9^{a} \pm 0,8$ & $6,3^{b} \pm 0,2$ \\
\hline Duração do $3^{\circ} \mathrm{FS}$ (dias) & - & $6,7 \pm 0,3$ \\
\hline Fase crescimento do $1^{\circ} \mathrm{FS}$ (dias) & $4,5 \pm 0,6$ & $3,8 \pm 0,4$ \\
\hline Fase de crescimento do $2^{\circ} \mathrm{FS}$ (dias) & $6,1^{\mathrm{a}} \pm 0,8$ & $3,8^{b} \pm 0,1$ \\
\hline Fase de crescimento do $3^{\circ} \mathrm{FS}$ (dias) & - & $4 \pm 0,2$ \\
\hline Fase de regressão $1^{\circ} \mathrm{FS}$ (dias) & $2,5 \pm 0,5$ & $3 \pm 0,3$ \\
\hline Fase de regressão do $2^{\circ} \mathrm{FS}$ (dias) & $2,8 \pm 0,3$ & $2,4 \pm 0,2$ \\
\hline Fase de regressão do $3^{\circ} \mathrm{FS}$ (dias) & - & $2,6 \pm 0,2$ \\
\hline Taxa de crescimento do $1^{\circ} \mathrm{FS}(\mathrm{mm} / \mathrm{d})$ & $0,83 \pm 0,1$ & $0,96^{\mathrm{A}} \pm 0,1$ \\
\hline Taxa de crescimento do $2^{\circ} \mathrm{FS}(\mathrm{mm} / \mathrm{d})$ & $0,68 \pm 0,1$ & $0,76^{\mathrm{B}} \pm 0,1$ \\
\hline Taxa de crescimento do $3^{\circ} \mathrm{FS}(\mathrm{mm} / \mathrm{d})$ & - & $0,88^{\mathrm{A}} \pm 0,1$ \\
\hline Máximo diâmetro do $1^{\circ} \mathrm{FS}(\mathrm{mm})$ & $7,3 \pm 0,5$ & $7,5 \pm 0,3$ \\
\hline Máximo diâmetro do $2^{\circ} \mathrm{FS}$ (mm) & $7,8 \pm 0,5$ & $7 \pm 0,2$ \\
\hline Máximo diâmetro do $3^{\circ} \mathrm{FS}(\mathrm{mm})$ & - & $7,6 \pm 0,4$ \\
\hline Dia do máximo diâmetro $1^{\circ} \mathrm{FS}$ & $4 \pm 0,8$ & $2,7 \pm 0,3$ \\
\hline Dia do máximo diâmetro $2^{\circ} \mathrm{FS}$ & $16,1^{\mathrm{a}} \pm 0,9$ & $12,1^{\mathrm{b}} \pm 0,6$ \\
\hline Dia do máximo diâmetro $3^{\circ} \mathrm{FS}$ & - & $18,2 \pm 0,6$ \\
\hline
\end{tabular}

a,b Médias com diferentes letras sobrescritas na mesma linha diferem a um nível de significância de 5\%.

A,B,C Médias com diferentes letras sobrescritas para a mesma coluna diferem a um nível de significância de 5\%.

* Dia $0=$ dia da ovulação.

Com relação ao maior FS em cada onda folicular entre os animais dos grupos $2 \mathrm{O}$ e $3 \mathrm{O}$ (Tabela 2.2), (1) a duração do $2^{\circ} \mathrm{FS}$ foi menor no 3O; (2) a fase de crescimento do $2^{\circ} \mathrm{FS}$ foi menor no 3O; (3) e o dia do máximo diâmetro do $2^{\circ} \mathrm{FS}$ foi precoce no 30 . Dentro do $2 \mathrm{O}$ não houve diferença $(\mathrm{P}>0,05)$ no desenvolvimento do FS nas diferentes ondas. Já entre os animais do $3 \mathrm{O},(1)$ a taxa de crescimento do $2^{\circ} \mathrm{FS}$ foi menor que a do $1^{\circ} \mathrm{FS}$ e $3^{\circ} \mathrm{FS}$.

\subsection{Volume luteal $\left(\mathrm{mm}^{3}\right)$}


Não houve diferença no desenvolvimento luteal entre os animais com duas e três ondas, desta forma optou-se por apresentar os valores médios das características do CL (Tabela 2.3) e o comportamento do desenvolvimento luteal (Figura 2.2).

Tabela 2.3. Características do CL e valores médios (média \pm EPM) observados nas fêmeas Curraleiras PéDuro.

\begin{tabular}{lc}
\hline Parâmetros & Valores Médios $(\mathrm{n}=19)$ \\
\hline Duração do CL (dias) & $20,6 \pm 1,8$ \\
Fase de crescimento (dias) & $7,7 \pm 2,1$ \\
Fase de manutenção (dias) & $6,2 \pm 2,4$ \\
Fase de regressão (dias) & $6,7 \pm 1,8$ \\
Máximo volume (mm ${ }^{3}$ ) & $5.486 \pm 1656$ \\
Dia do máximo volume & $9,4 \pm 2,5$ \\
\hline
\end{tabular}

* Dia $0=$ dia da ovulação

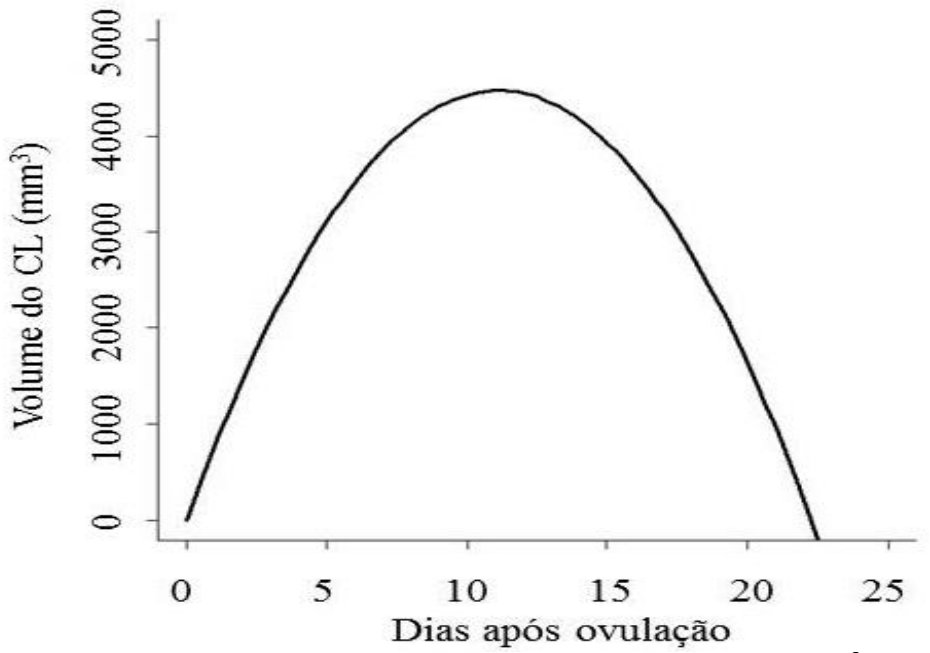

Figura 2.3. Equação de regressão do volume do $\mathrm{CL}\left(\mathrm{mm}^{3}\right)$ ao longo do ciclo estral de fêmeas $(\mathrm{n}=19)$ da raça Curraleiro PéDuro. $\mathrm{Y}=787,66 \mathrm{x}-34,44 \mathrm{x}^{2}, \mathrm{R}^{2}=0,93$, em que $\mathrm{Y}=$ volume do CL e $\mathrm{x}=$ dia da mensuração. 


\section{DISCUSSÃO}

Acredita-se que esta foi a primeira descrição da dinâmica folicular ovariana em fêmeas da raça taurina localmente adaptada Curraleiro Pé-Duro em condições de clima tropical seco. Os resultados demonstraram que não houve diferença no desenvolvimento folicular e luteal entre vacas (pluríparas e não lactantes) e novilhas. Em contrapartida, Wolfenson et al., (2004) encontraram diferenças na dinâmica folicular entre novilhas solteiras e vacas lactantes na raça Holandesa, provavelmente devido aos diferentes momentos da vida reprodutiva entre as fêmeas, refletindo as diferenças metabólicas de ambas categorias.

Houve predominância de dois padrões de desenvolvimento folicular, duas ondas $(36,8 \%=7 / 19)$ e três ondas $(63,2 \%=12 / 19)$, semelhante ao encontrado em outros estudos (Ginther et al., 1989; Alvarez et al., 2000; Noseir et al., 2003; Wolfenson et al., 2004; Jaiswal et al., 2009). A ocorrência de apenas uma fêmea com quatro ondas foliculares no presente trabalho está de acordo com os dados da literatura (; Savio et al., 1988; Sirois \& Fortune, 1988; Rhodes et al., 1995; Figueiredo et al., 1997), nos quais este padrão de ondas foi pouco observado. Alguns trabalhos relatam a maior ocorrência de animais com três ondas foliculares (Savio et al., 1988; Sirois \& Fortune, 1988; Rhodes et al., 1995; Noiser et al., 2003), já outros encontraram uma maior proporção de animais com duas ondas (Ginther et al., 1989; Alvarez et al., 2000; Townson et al., 2002; Wolfenson et al., 2004), existindo então esta divergência. A diferença nos resultados pode ter origem na predisposição genética, condições ambientais diferenciadas e fatores nutricionais (Boland et al., 2001). Estes fatores podem influenciar as concetrações de estradiol$17 \beta$ (E2) sérico e consequentemente o número de picos do hormônio folículo estimulante (FSH) que estimulam o início de uma nova onda folicular (Adams et al., 1992). 
O intervalo entre ovulações foi semelhante entre os animais do grupo $2 \mathrm{O}(21,4 \pm$ $0,4 \mathrm{~d})$ e $3 \mathrm{O}(22,3 \pm 0,6 \mathrm{~d})$, o que contraria o observado em outros estudos (Alves et al., 2002; Noiser et al., 2003; Wolfenson et al., 2004; Jaiswal et al., 2009), nos quais os animais com três ondas foliculares tinham intervalo entre ovulações maior. Contudo, Savio et al., (1988) e Ahmad et al., (1997) também não encontraram diferença no intervalo entre ovulações, nos animais com duas e três ondas foliculares, em novilhas e vacas Bos taurus.

Ginther et al., (1989) relataram que o aparecimento da terceira onda folicular estaria relacionado com a maior duração da fase luteal, o que não foi observado no presente estudo (19,8 \pm 0,7 d, 20 vs $21 \pm 0,5$ d, 3O). A hipótese de que a duração (dias) da primeira onda folicular determinaria o padrão de ondas (Jaiswal et al., 2009) também não foi observada no trabalho, dada à igualdade na duração $(14,2 \pm 1,0 \mathrm{~d}, 2 \mathrm{O}$ vs 15,3 \pm 0,7 d, 3O) e fase de dominância $(8,7 \pm 0,6 \mathrm{~d}, 2 \mathrm{O}$ vs $9,3 \pm 0,4 \mathrm{~d}, 3 \mathrm{O})$ do FD. Noseir (2003) creditou o surgimento da terceira onda ao fato do segundo FD não ser capaz de atingir diâmetro e concentração de E2 sérico maior que $10 \mathrm{~mm}$ e $5 \mathrm{pg} / \mathrm{ml}$, respectivamente, estando de acordo com tamanho folicular observado no estudo.

O intervalo estro-ovulação encontrado (24,8 a 26 horas) foi semelhante ao observado na literatura (Cavalieri et al., 1997; Pinheiro et al., 1998; Wolfenson et al., 2004). A identificação do momento do estro é fundamental para o desenvolvimento de biotecnologias como a inseminação artificial (IA) e a múltipla ovulação e transferência de embriões (MOTE; Galina \& Orihuela, 2007). O resultado encontrado nas fêmeas Curraleiras Pé-Duro, corrobora com a prática de inseminar 12 horas após detecção do estro (Dorsey et al., 2011), pois permitiria um tempo em torno de 13,4 horas para a capacitação espermática.

Independentemente do grupo (2O ou 3O), o momento da emergência folicular da primeira onda foi verificada em até 24 horas após ovulação, sendo precoce ao relatado para fêmeas Bos indicus (Figueiredo et al., 1997), porém semelhante a fêmeas Bos taurus (Ginther et al., 1989). O dia da emergência da segunda onda $(11,1 \pm 0,4 \mathrm{~d})$, para animais do $2 \mathrm{O}$, e da segunda $(9,1 \pm 0,6 \mathrm{~d})$ e terceira ondas $(15,1 \pm 0,6 \mathrm{~d})$, para os animais do 30 corrobora com outros trabalhos em animais Bos taurus e Bos indicus (Sirois \& Fortune, 1988; Rhodes et al., 1995; Ahmad et al., 1997; Wolfenson et al., 2004). Rhodes et al. (1995) e Jaiswal et al. (2009) sugeriram que a emergência precoce da segunda onda nos animais com três ondas poderia ser devido ao menor período de dominância do $1^{\circ}$ FD. Contudo, no presente estudo não houve 
diferença na fase de dominância do $1^{\circ} \mathrm{FD}(8,7 \pm 0,6 \mathrm{~d}, 2 \mathrm{O}$ vs 9,3 $\pm 0,4 \mathrm{~d}, 3 \mathrm{O})$, assim como em outros trabalhos (Ginther et al., 1989; Figueiredo et al., 1997; Noseir, 2003). O conhecimento do dia da emergência folicular é importante para a utilização da MOTE, por exemplo, pois esta biotécnica reprodutiva apresenta melhores resultados quando iniciada no momento da mesma (Mapletof et al., 2009).

O número de folículos no início das ondas foliculares foi similar ao encontrado por Savio et al. (1988) em novilhas holandesas, porém inferior ao observado por Alvarez et al. (2000) em vacas pluríparas lactantes das raças Angus, Brahman e Senepol. As diferenças encontradas podem estar associadas a diferentes concentrações hormonais do E2, FSH, fator de crescimento semelhante à insulina (IGF-1) e do hormônio do crescimento $(\mathrm{GH})$ entre raças Bos taurus e Bos indicus (Alvarez et al., 2000). Estes pesquisadores verificaram que a concentração de IGF-1 na raça Senepol (Bos taurus adaptada ao clima tropical) era inferior à raça Brahman (Bos indicus) e superior a raça Angus (Bos taurus). Esta, provavelmente, é uma das causas do maior número de folículos pequenos $(<5 \mathrm{~mm})$ na raça Brahman, seguido pela Senepol e Angus. Burns et al. (2005), estudando vacas Holandesas verificaram que, as com maior número de folículos no ovário, tinham uma concentração menor de FSH em relação as com menor número de folículos, contudo não houve diferença na concentração de E2 e IGF-1. Este achado evidencia que outros fatores além do FSH e IGF-1 podem estar envolvidos na regulação do número de folículos dentro do ovário e consequentemente na emergência. O conhecimento das concentrações hormonais e fatores de crescimento ao longo do ciclo nas fêmeas Curraleiras Pé-Duro em futuros estudos torna-se importante para a utilização da MOTE. Isto porque, existem diferenças na concentração fisiológica de determinados hormônios (Alvarez et al., 2000) e de sensibilidade a estimulação com FSH nos animais Bos taurus e Bos indicus (Barros \& Nogueira, 2001). O maior número de folículos na primeira onda folicular em relação a segunda nos animais do grupo 30 e a maior variação no momento do início da segunda onda (Baruselli et al., 2006; Ginther et al., 1989), sugerem a maior eficiência do tratamento de superovulação se realizado durante a primeira onda folicular. Adams et al. (1994) não encontraram diferença na resposta superovulatória utilizando a primeira ou segunda onda, contudo sugere a utilização da primeira devido a menor variação em sua emergência. Nasser et al. (1993) relataram que quanto mais próximo da emergência folicular o tratamento superovulatório for realizado, melhor será o resultado. 
No grupo 3O, a duração e a fase de dominância $(7,2 \pm 0,2$ d) do FO, foi menor que nos dominantes anteriores, contudo a taxa de crescimento $(1,2 \pm 0,1 \mathrm{~mm} / \mathrm{d}$ vs $0,9 \pm 0,1 \mathrm{~mm} / \mathrm{d}$ e 1 $\pm 0,1 \mathrm{~mm} / \mathrm{d})$ foi inversa, sendo maior no FO. A duração do $1^{\circ} \mathrm{FD}(15,3 \pm 0,8 \mathrm{~d})$ foi semelhante ao encontrado em novilhas Holandesas (16,9 \pm 0,9 d, Sirois \& Fortune, 1988), porém maior do que em vacas Nelore (13 \pm 0,6 d, Figueiredo et al., 1997) e novilhas Hereford (11,3 \pm 0,8 d, Savio et al., 1988). O $2^{\circ}$ FD $(11,4 \pm 0,5$ d) teve duração semelhante ao encontrado em fêmeas Nelore (11,5 \pm 0,42 d, Figueiredo et al., 1997), menor que nas novilhas Holandesas $(13,1 \pm 0,8 \mathrm{~d}$, Sirois \& Fortune, 1988) e maior que nas novilhas Hereford (7,3 \pm 0,8 d, Savio et al., 1988). Já a duração do FO (7,2 \pm 0,2 d) foi semelhante nas fêmeas Nelore $(6,8 \pm 0,5$ d, Figueiredo et al., 1997) e novilhas Holandesas (6,1 \pm 0,7 d, Sirois \& Fortune, 1988), porém menor que em novilhas Hereford (5,9 \pm 0,3 d, Savio et al., 1988). Estas semelhanças na dinâmica folicular ora para com animais Bos taurus ora para com animais Bos indicus, refletem os cruzamentos realizados na raça de origem europeia com o gado Zebu ao longo dos anos. Egito (2007) estudando a caracterização genética das raças no Brasil verificou uma grande riqueza de alelos nas raças localmente adaptadas em relação às taurinas e indianas puras, devido à miscigenação desde os tempos coloniais. Além disto, as raças locais tiveram uma menor distância genética para com as indianas em relação às européias puras, muito provavelmente pelo cruzamento destas, objetivando animais mais resistentes e rústicos. Além da miscigenação, as características adaptativas adquiridas ao longo dos anos também influenciaram na maior proximidade dos parâmetros reprodutivos para com os animais Bos indicus.

No grupo 2O, a duração do FO $\left(10 \pm 0,3\right.$ d) foi menor do que a do $1^{\circ}$ FD $(14,2 \pm$ $1,1 \mathrm{~d})$, contudo a fase de dominância $\left(10 \pm 0,3,1^{\circ} \mathrm{FD}\right.$ e $\left.8,71 \pm 0,6 \mathrm{~d}, \mathrm{FO}\right)$ e a taxa de crescimento $\left(0,80 \pm 0,03 \mathrm{~mm} / \mathrm{d}, 1^{\circ} \mathrm{FD}\right.$ e $\left.1,02 \pm 0,09 \mathrm{~mm} / \mathrm{d}, \mathrm{FO}\right)$ foram semelhantes para ambos os folículos dominantes, ao contrário dos animais com três ondas. A duração do $1^{\circ} \mathrm{FD}(14,2 \pm 1,1 \mathrm{~d})$ e $2^{\circ} \mathrm{FD}$ $(10 \pm 0,3 \mathrm{~d})$ foi semelhante ao encontrado por Figueiredo et al. (1997) em vacas Nelore (14,7 \pm $0,7 \mathrm{~d}, 1^{\circ} \mathrm{FD}$ e $\left.9 \pm 0,6 \mathrm{~d}, 2^{\circ} \mathrm{FD}\right)$ e por Savio et al. (1988) em novilhas Hereford $\left(14,2 \pm 2,8 \mathrm{~d}, 1^{\circ}\right.$ FD e $9 \pm 1$ d, $2^{\circ}$ FD). Na comparação do FO dos animais dos grupos $2 \mathrm{O}$ vs 3O, os primeiros tiveram uma duração e fase de dominância maior que os segundos, semelhante ao encontrado em outros trabalhos (Savio et al., 1988; Ahmad et al., 1997; Figueiredo et al., 1997; Townson et al., 2002). Alguns trabalhos relacionam a maior duração do FO a um comprometimento da qualidade 
oocitária (Ahmad et al., 1995; Austin et al., 1999), e consequentemente uma menor taxa de prenhez (Ahmad et al., 1997; Townson et al., 2002).

A taxa de crescimento do FO dos animais com duas ondas $(0,8 \pm 0,1 \mathrm{~mm} / \mathrm{d})$ foi inferior a dos com três ondas $(1,2 \pm 0,1 \mathrm{~mm} / \mathrm{d})$, sendo semelhante aos dados de Ahmad et al. (1997) que observaram para animais com duas e três ondas, $1 \pm 0,1 \mathrm{~mm} / \mathrm{d}$ e $1,5 \pm 0,1 \mathrm{~mm} / \mathrm{dia}$, respectivamente. As taxas de crescimento independentemente do padrão folicular foram menores do que relatado em animais Bos taurus $(1,6 \mathrm{~mm} / \mathrm{d}$, Sirois \& Fortune, 1988; 3 a 5,5 mm/d, Savio et al., 1988). Em relação aos animais Bos indicus com duas e três ondas foliculares, a taxa de crescimento do FO foi próxima $(0,9 \pm 0,1$ e 1,1 \pm 0,1 mm/d, Figueiredo et al., 1997; 0,8 \pm 0,1 e 1,1 $\pm 0,1 \mathrm{~mm} / \mathrm{d}$, Coutinho et al., 2007), respectivamente. Segundo Rhodes et al. (1995) e Noiser (2003), uma menor concentração de P4 durante o desenvolvimento da terceira onda pode resultar em uma maior taxa de crescimento do FO, o que foi verificado nas vacas Curraleiras. A menor concentração de P4 permite uma maior pulsatilidade do hormônio luteinizante (LH) estimulando assim o crescimento folicular (Fortune, 1994). Por outro lado, o tamanho do $2^{\circ}$ FD no grupo 30 foi menor provavelmente devido à alta concentração de P4, produzida por um CL maduro, durante seu desenvolvimento, inibindo assim a pulsatilidade de LH (Sirois \& Fortune, 1988; Figueiredo et al., 1997).

O tamanho do FD nos animais com duas ondas $\left(10,6 \pm 0,3 \mathrm{~mm}, 1^{\circ} \mathrm{FD}\right.$ e $12,1 \pm 0,2$ $\left.\mathrm{mm}, 2^{\circ} \mathrm{FD}\right)$ e três ondas $\left(12,5 \pm 0,4 \mathrm{~mm}, 1^{\circ} \mathrm{FD}, 9,9 \pm 0,2 \mathrm{~mm}, 2^{\circ} \mathrm{FD}\right.$ e $\left.13,1 \pm 0,3 \mathrm{~mm}, 3^{\circ} \mathrm{FD}\right)$ foi semelhante ao encontrado em fêmeas Bos indicus (10 a 14 mm, Coutinho et al., 2007; 10 a 12 mm, Figueiredo et al., 1997; e 10 a 11 mm, Rhodes et al., 1995). Contudo, estudos em animais Bos taurus relataram tamanho de FD maior do que o observado no presente estudo (13 a $18 \mathrm{~mm}$, Ginther et al., 1989; 13 a 15 mm, Jaiswal et al., 2009; 14 a 20 mm, Savio et al., 1988; 16 a 17 mm, Townson et al., 2002; e 13 a 16,5 mm, Wolfenson et al., 2004). O maior FD nas raças Bos taurus provavelmente é devido a maior taxa de crescimento observada nestes animais (Savio et al., 1988; Sirois \& Fortune, 1988). A diferença encontrada entre o taurino Curraleiro Pé-Duro e os trabalhos citados em animais Bos taurus puros, pode estar situada na introgressão de genes sofrida pela raça devido aos cruzamentos com animais indianos ao longo dos anos (Egito, 2007).

Alvarez et al. (2000) estudando a raça Senepol (Bos taurus tropicalmente adaptada), encontraram tamanho de FO (13,6 \pm 0,4 $\mathrm{mm})$ semelhante ao presente estudo. $\mathrm{O}$ tamanho do FO independentemente do padrão de ondas foi superior ao das ondas anteriores 
provavelmente devido à menor concentração de P4 durante seu crescimento (Savio et al., 1988; Rhodes et al., 1995). Vários estudos relacionam o maior tamanho do FO com uma maior taxa de ovulação (Sartori et al., 2001; Gimenes et al., 2008), volume luteal (Vasconcelos et al., 2001), concentração de P4 (Tortorella et al., 2013) e taxa de prenhez (Sá Filho et al., 2010). O maior tamanho do FO nos animais do 30 em relação ao 2O, devido a maior taxa de crescimento, vai contra ao observado em outros trabalhos (Ginther et al., 1989; Alves et al., 2002; Bleach et al., 2004; Coutinho et al., 2007). Nestes trabalhos, o maior período de dominância do FO nos animais com duas ondas compensou a menor taxa de crescimento, o que levou a um maior FO em relação aos animais com três ondas. No presente estudo, também foi observado um maior período de dominância nos animais do $2 \mathrm{O}$, porém este fator não foi suficiente para compensar a grande diferença na taxa de crescimento para com os animais do 30.

O dia do máximo diâmetro dos FDs nos animais com duas $(5,8 \pm 0,9$ d e $20 \pm 0,5$ d) e três ondas $(6,5 \pm 0,5 \mathrm{~d}, 14,4 \pm 0,8 \mathrm{~d}$ e 21,5 \pm 0,6 d) assemelha-se ao encontrado por Savio et al. (1988) e Ginther et al. (1989) em novilhas Bos taurus, e e Alves et al. (2002) e Coutinho et al. (2007) em vacas Bos indicus.

Em relação ao maior FS o máximo diâmetro encontrado foi bem menor em relação ao FD em cada respectiva onda, não sendo influenciado pelo padrão de ondas. Independentemente da onda folicular o máximo tamanho do FS (7 a $8 \mathrm{~mm}$ ) foi similar ao encontrado em vacas Guzerá (7 a 8,5 mm) por Coutinho et al. (2007) e em novilhas holandesas (6,5 a 8,5 mm) por Sirois \& Fortune (1988). O menor tamanho do FS em relação ao FD deve-se a inibição desses últimos para com os primeiros, pela produção de E2 e inibina, diminuindo as concentrações de FSH e consequentemente o estímulo para o crescimento dos menores folículos. A menor concentração de FSH não afeta o crescimento do FD, pois neste momento, o folículo se encontra em estágio diferenciado (dependência de LH) e suporta o crescimento em baixas concentrações de FSH (Adams et al., 1992; Fortune, 1994; Ginther et al., 2001).

A primeira visualização do CL foi feita dois dias após ovulação em todos os animais, sendo seu acompanhamento possível de ser realizado até em torno de um dia antes da ovulação seguinte. A duração do acompanhamento luteal foi superior ao relatado por Coutinho et al. (2007), que identificaram o CL quatro dias após ovulação e o acompanharam por 15 a 17 dias. O CL cresceu em torno de 7 a 9 dias mantendo-se estável até em torno do dia 14 da sua visualização ( \pm 16 dias do ciclo), quando se iniciou a regressão morfológica, assemelhando-se ao 
encontrado por Jaiswal et al. (2009). O máximo volume luteal $\left(5.486 \pm 1.656 \mathrm{~mm}^{3}\right)$ atingido em torno de 9 a 11 dias após a ovulação está de acordo com o encontrado por Alvarez et al. (2000), Jaiswal et al. (2009) e Wolfenson et al. (2004), nas raças Senepol, Hereford e Holandesa, respectivamente. Entretanto Rhodes et al. (1995) e Figueiredo et al. (1997) trabalhando com animais Bos indicus encontraram tamanho luteal menor do que o observado no presente trabalho. Vasconcelos et al. (2001) e Tortorella et al. (2013) verificaram que um maior FO da origem a um CL de maiores dimensões, o que não foi observado nos animais do 30 em relação ao 20. Variações na metodologia do acompanhamento luteal, categoria animal, época do trabalho e aporte nutricional podem estar envolvidos na diferença de um estudo e outro.

O estudo demonstrou que não existem diferenças na dinâmica folicular entre novilhas e vacas cíclicas e não lactantes Curraleiras Pé-Duro, havendo uma predominância no padrão de 3 ondas foliculares. O Curraleiro Pé-Duro possui algumas características foliculares semelhantes a animais Bos taurus e outras a Bos indicus, corroborando com a ideia de que ao longo dos anos, cruzamentos planejados ou não, foram realizados. O conhecimento adquirido servirá de base para o desenvolvimento de protocolos hormonais, que visam manipular o ciclo estral para utilização da IA, IATF e MOTE, com o objetivo de aumentar o número de descendentes e estimular a criação. 


\section{AGRADECIMENTOS}

Os autores agradecem a CAPES pela bolsa de estudo, ao CNPq e a FAP-DF pelo suporte financeiro e a Rede Centro-Oeste de Pós-Graduação, Pesquisa e Inovação. 


\section{REFERÊNCIAS BIBLIOGRÁFICAS}

ADAMS, G.P.; MATTERI, R.L.; KÄSTELTE, J.P. et al. Association between surges of follicle stimulating hormone and the emergence of follicular waves in heifers. Journal of Reproduction and Fertility, v. 94, p. 177-188, 1992.

ADAMS,G.P.; NASSER, L.F.; BO, G.A. et al. Superovulatory response of ovarian follicles of Wave 1 versus Wave 2 in heifers. Theriogenology, v. 42, p.1103-1 113, 1994.

AHMAD, N.; SCHRICK, F.N.; BUTCHER, R.L. et al. Effect of persistent follicles on early embryonic losses in beef cows. Biology of Reproduction, v. 52, p. 1129-1135, 1995.

AHMAD, N.; TOWNSEND, E.C.; DAILY, R.A. et al. Relationships of hormonal patterns and fertility to occurrence of two or three waves of ovarian follicles before and after breeding in beef cows and heifers. Animal Reproduction of Science, v. 49, p. 13-28, 1997.

ALVAREZ, P.; SPICER, L.J.; CHASE, C.C. et al. Ovarian and endocrine characteristics during an estrous cycle in Angus, Brahman, and Senepol cows in a subtropical environment. Journal of Animal Science, v. 78, p. 1291-1302, 2000.

ALVES, N.G.; COSTA, E.P.; GUIMARÃES, J.D. et al. Ovarian Activity in Holstein and Crossbreed Holstein x Zebu Cows During Two Normal Estrous Cycles. Brazilian Journal of Zootechnology, v. 31, p. 627-634, 2002.

AUSTIN, E.J.; MIHM, M.; RYAN, M.P. et al. Effect of duration of dominance of the ovulatory follicle on onset of estrus and fertility in heifers. Journal of Animal Science, v. 77, p. 22192226, 1999.

BARROS, C.M.; NOGUEIRA, M.F.G. Embryo transfer in Bos indicus cattle. Theriogenology, v. 56, p. 1483-1496, 2001.

BARUSELLI, P.S.; FILHO, M.S.F.; MARTINS, C.M. et al. Superovulation and embryo transfer in Bos indicus cattle. Theriogenology, v. 65, p. 77-88, 2006. 
BARUSELLI, P.S.; GIMENES, L.U.; SALES, J.N.S. Reproductive physiology of Bos taurus and Bos indicus females. Animal Reproduction, v. 31, p. 205-211, 2007.

BIANCHINI, E.; CONCECPTA, M.; LUCCI, C.M. et al. Body traits associated with heat adaptation in naturalized Brazilian cattle breeds. Brazilian Agriculture Research, v. 41, p. 1443-1448, 2006.

BLEACH, E.C.L.; GLENCROSS, R.G.; KNIGHT, P.G. Association between ovarian follicle development and pregnancy rates in dairy cows undergoing spontaneous oestrous cycles. Reproduction, v. 127, p. 621-629, 2004.

BÓ, G.A.; BARUSELLI, P.S.; CHESTA, P.M. et al. The timing of ovulation and insemination schedules in superstimulated cattle. Theriogenology, v. 65, p. 89-101, 2006.

BOLAND, M.P.; LONERGRAN, P.; O'CALLAGHAN, D. Effect of nutrition on endocrine parameters ovarian physiology and oocyte and embryo development. Theriogenology, v. 55, p. 1323-1340, 2001.

BURNS, D.S.; JIMENEZ-KRASSEL, F.; IRELAND, J.L.H. et al. Numbers of Antral Follicles During Follicular Waves in Cattle- Evidence for High Variation Among Animals, very high repeatability in individuals, and an inverse association with serum follicle-stimulating hormone concentrations. Biology of Reproduction, v. 73, p. 54-62, 2005.

CASTILHO, C.; GARCIA, J.M.; RENESTO, A. et al. Follicular dynamics and plasma FSH and progesterone concentrations during follicular deviation in the first post-ovulatory wave in Nelore (Bos indicus) heifers. Animal Reproduction of Science, v. 98, p. 189-196, 2007.

CAVALIERI, J.; RUBIO, I.; KINDER, J.E. et al. Synchronization of estrus and ovulation and associated endocrine changes in Bos indicus cows. Theriogenology, v. 47, p. 801-814, 1997.

COUTINHO, G.T.R.M.; VIANA, J.H.M.; SÁ, W.F. et al. Ultrasonographic evaluation of follicular dynamics and luteal function in Guzerá cows. Brazilian Archive of Medicine Veterinary and Zootechnology, v. 59, p. 1089-1096, 2007.

DORSEY, B.R.; KASIMANICKAM, R.; WHITTIER, W.D. et al. Effect of time from estrus to AI on pregnancy rates in estrous synchronized beef heifers. Animal Reproduction of Science, v. 127, p. 1-6, 2011.

EGITO, Andrea Alves. Diversidade genética, ancestralidade individual e miscigenação nas raças bovinas com base em microssatélites e haplótidos de DNA mitocondrial: subsídios para a conservação. Brasília: Instituto de Ciências Biológicas da Universidade de Brasília, 2007. 246p. Tese (Doutorado em Ciências Biológicas) - Instituto de Ciências Biológicas, Departamento de Biologia Molecular da Universidade de Brasília, 2007.

EGITO, A.A.; MARIANTE, A.S.; ALBUQUERQUE, M.S.M. The Brazilian Genetic Resources Conservation Program. Archives of Zootechnology, v. 51, p. 39-52, 2002. 
FIGUEIREDO, R.A.; BARROS, C.M.; PINHEIRO, O.L. et al. Ovarian follicular dynamics in Nelore breed (Bos indicus) cattle. Theriogenology, v. 41, p. 1489-1505, 1997.

FIORAVANTI, M.C.S.; JULIANO, R.S.; COSTA, G.L. et al. Conservación del bovino Curraleiro: cuantificación del censo y caracterización de los criadores. Animal Genetic and Resources, v. 48, p. 109-116, 2011.

FORTUNE, J.E. Ovarian follicular growth and development in mammals. Biology of Reproduction, v. 50, p. 225-232, 1994.

GALINA, C.S.; ORIHUELA, A. The detection of estrus in cattle raised under tropical conditions: What we know and what we need to know. Hormonal Behaviour, v. 52, p. 32-38, 2007.

GIMENES, L.U.; SA FILHO, M.F.; CARVALHO, N.A. et al. Follicle deviation and ovulatory capacity in Bos indicus heifers. Theriogenology, v. 69, p. 852-858, 2008.

GINTHER, O.J.; BEG, M.A., BERGFELT, D.R. et al. Follicle Selection in Monovular Species. Biology of Reproduction, v. 65, p. 638-647, 2001.

GINTHER, O.J.; KNOPF, L.; KASTELIC, J.P. Temporal associations among ovarian events in cattle during oestrous cycles with two and three follicular waves. Journal of Reproduction and Fertility, v. 87, p. 223-230, 1989.

JAISWAL, R.S.; SINGH, J.; MARSHALL, L. et al. Repeatability of 2-wave and 3-wave patterns of ovarian follicular development during the bovine estrous cycle. Theriogenology, v. 72, p. 8190, 2009.

MAPLETOFT, R.J; BÓ, G.A. et al. Control of ovarian function for assisted reproductive technologies in cattle. Animal Reproduction, v. 6, p. 114-124, 2009.

MARIANTE, A.S.; EGITO, A.A. Animal Genetic resources in Brazil: result of five centuries of natural selection. Theriogenology, v. 57, p. 223-235, 2002.

NASSER, L.F.; ADAMS, G.P.; BO, G.A. et al. Ovarian superstimulatory response relative to follicular wave emergence in heifers. Theriogenology, v. 40, p. 713-724, 1993.

NEIVA, A.C.G.R.; SERENO, J.R.B.; FIORAVANTI, M.C.S. Indicação geográfica na conservação e agregação de valor ao gado Curraleiro da comunidade Kalunga. Archives of Zootechnology, v. 60, p. 357-360, 2011.

NOSEIR, W.M.B. Ovarian follicular activity and hormonal profile during estrous cycle in cows: the development of 2 versus 3 waves. Reproductive Biology and Endocrinology, v. 1, p. 50-55, 2003.

PINHEIRO, O.L.; BARROS, C.M.; FIGUEIREDO, R.A. et al. Estrous behavior and the estrusto-ovulation interval in Nelore cattle (Bos indicus) with natural estrus or estrus induced with 
prostaglandin F2 $\alpha$ or norgestomet and estradiol valerate. Theriogenology, v. 49, p. 667-681, 1998.

PRIMO, A.T. The Iberic cattle in the Americas: 500 years later. Archives of Zootechnology, v. 41, p. 421-432, 1992.

RHODES, F.M.; DE'ATH, G.; ENTWISTLE, K.W. Animal and temporal effects on ovarian follicular dynamics in Brahman heifers. Animal Reproduction of Sience, v. 38, p. 265-277, 1995.

SA FILHO, M.F.; CRESPILHO, A.M.; SANTOS, J.E. et al. Ovarian follicle diameter at timed insemination and estrous response influence likelihood of ovulation and pregnancy after estrous synchronization with progesterone or progestin-based protocols in suckled Bos indicus cows. Animal Reproduction of Sience, v. 120, p. 23-30, 2010.

SA FILHO, M.F.; CRESPILHO, A.M.; SANTOS, J.E. et al. Ovarian follicle diameter at timed insemination and estrous response influence likelihood of ovulation and pregnancy after estrous synchronization with progesterone or progestin-based protocols in suckled Bos indicus cows. Animal Reproduction of Sience, v. 120, p. 23-30, 2010.

SÁ FILHO, M.F.; PENTEADO, L.; REIS, E.L et al. Timed artificial insemination early in the breeding season improves the reproductive performance of suckled beef cows. Theriogenology, v. 79, p. 625-632, 2013.

SARTORI, R.; FRICKE, P.M.; FERREIRA, J.C.P. et al. Follicular deviation and acquisition of ovulatory capacity in bovine follicles. Biology of Reproduction, v. 65, p. 1403-1409, 2001.

SAVIO, J.D.; KEENAN, L.; BOLAND, M.P. et al. Pattern of growth of dominant follicles during the oestrous cycle of heifers. Journal of Reproduction and Fertility, v. 83, p. 663-671, 1988.

SERRANO, G.M.; EGITO, A.A.; MCMANUS, C. et al. Genetic diversity and population structure of Brazilian native bovine breeds. Brazilian Agriculture Research, v. 39, p. 543-549, 2004.

SIROIS, J.; FORTUNE, J.E. Ovarian follicular dynamics during the estrous cycle in heifers monitored by real-time ultrassonography. Biology of Reproduction, v. 39, p. 308-317, 1988.

TORTORELLA, R.D.; FERREIRA, R.; SANTOS, J.T. et al. The effect of equine chorionic gonadotropin on follicular size, luteal volume, circulating progesterone concentrations, and pregnancy rates in anestrous beef cows treated with a novel fixed-time artificial insemination protocol. Theriogenology, v. 79, p. 1204-1209, 2013.

TOWNSON, D.H.; TSANG, P.C.W.; BUTLER, W.R. et al. Relationship of fertility to ovarian waves before breeding in dairy cows. Journal of Animal Science, v. 80, p. 1053-1058, 2002. 
VASCONCELOS, J.L.; SARTORI, R.; OLIVEIRA, H.N. et al. Reduction in size of the ovulatory follicle reduces subsequent luteal size and pregnancy rate. Theriogenology, v. 56, p. 307-314, 2001.

WILDMAN, E.E.; JONES, G.M.; WAGNER, P.E. A dairy cow body condition scoring system and its relationship to selected production characteristics. Journal of Dairy Science, v. 65, p. 495-501, 1982.

WOLFENSON, D.; INBAR, G.; ROTH, Z. et al. Follicular dynamics and concentrations of steroids and gonadotropins in lactating cows and nulliparous heifers. Theriogenology, v. 62, p. 1042-1055, 2004. 


\section{CAPÍTULO 3}

\section{EMERGÊNCIA E DIVERGÊNCIA NA PRIMEIRA ONDA FOLICULAR EM BOVINOS LOCALMENTE ADAPTADOS DA RAÇA CURRALEIRO PÉ-DURO}

Rodrigo Dorneles Tortorella ${ }^{\mathrm{a}, \mathrm{c}}$, Mairon Rocha Modesto ${ }^{\mathrm{b}}$, Priscilla Passoni Silva ${ }^{\mathrm{b}}$, Joseane Padilha da Silva ${ }^{\mathrm{c}}$, Jairo Pereira Neves ${ }^{\mathrm{a}}$, Alexandre Floriani Ramos ${ }^{\mathrm{c}}$

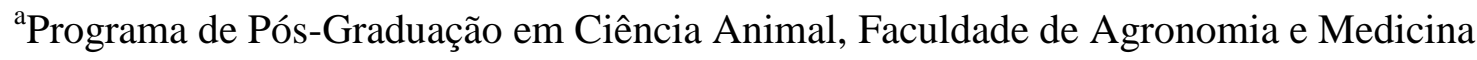
Veterinária, Universidade de Brasília, UnB, Brasília, Distrito Federal, Brasil;

${ }^{\mathrm{b}}$ Faculdades Integradas da União Educacional do Planalto Central, FACIPLAC, Brasília, Distrito Federal, Brasil;

${ }^{c}$ Embrapa Recursos Genéticos e Biotecnologia, Brasília, Distrito Federal, Brasil; 


\section{RESUMO}

O objetivo do estudo foi avaliar a emergência e divergência folicular na raça localmente adaptada Curraleiro Pé-Duro, a fim de obter parâmetros fisiológicos que permitam a manipulação hormonal para inseminação artificial em tempo fixo (IATF) e a múltipla ovulação e transferência de embriões (MOTE). Novilhas $(n=11)$ e vacas $(n=11)$ não lactantes e cíclicas foram avaliadas pelo ultrassom a cada 8 horas até 5 dias após a ovulação. Houve diferença somente no tempo entre a ovulação e emergência $(11,6 \pm 3,3 \mathrm{~h}$ versus $20,3 \pm 2,5 \mathrm{~h}, \mathrm{P} \leq 0,05)$ e a ovulação e divergência $(52,4 \pm 5,2 \mathrm{~h}$ versus $71,8 \pm 4,1 \mathrm{~h}, \mathrm{P} \leq 0,05)$ entre vacas e novilhas, respectivamente. Após a emergência folicular, ambas as categorias animais apresentaram características foliculares semelhantes. Consequentemente, após emergência os dados de vacas e novilhas foram unificados de acordo com o folículo dominante (FD) e maior folículo subordinado (FS). O FD e o FS foram identificados em um mesmo momento $(\mathrm{P}>0,05)$. O número de folículos pequenos $(\leq 4 \mathrm{~mm}, 7,2$ $\pm 5,1)$ e médios $(4 \mathrm{a} \leq 8 \mathrm{~mm}, 6,8 \pm 3,5)$ foi superior $(\mathrm{P} \leq 0,05)$ ao número de folículos grandes $(\geq$ $8 \mathrm{~mm}, 0,6 \pm 0,5$ ) ao longo dos 5 dias de avaliação. No momento da divergência (em torno de 45 horas após a emergência) o tamanho do $\mathrm{FD}(8,1 \pm 1 \mathrm{~mm})$ não diferiu $(\mathrm{P}>0,05)$ do $\mathrm{FS}(7,6 \pm 0,9$ $\mathrm{mm})$. A taxa de crescimento do FD e FS foi similar até a divergência, sendo que após, a taxa no FD manteve-se positiva enquanto que o FS regrediu. Em resumo, as vacas tiveram uma emergência e divergência folicular em relação a ovulação precoce quando comparadas as novilhas. Este achado aliado ao conhecimento da população folicular no início da onda, momento da divergência em relação a emergência, tamanho do FD na divergência e período de crescimento serão importantes para aplicação da IATF e da MOTE.

Palavras-chave: conservação, dinâmica folicular, folículo dominante, recursos genéticos. 


\section{ABSTRACT}

The aim of the present study was to characterize ovarian follicular emergence and deviation in locally adapted Curraleiro Pé-Duro cows and heifers. Cyclic heifers ( $\mathrm{n}=11)$ and non-lactating, multiparous cows $(n=11)$ were examined every 8 hours by ultrasonography and from the day next to the last injection of $\mathrm{PGF}_{2 \alpha}$ to five days after ovulation (D 0). The interval from ovulation to emergence $(11.6 \pm 3.3 \mathrm{~h}$ versus $20.3 \pm 2.5 \mathrm{~h}, \mathrm{P} \leq 0.05)$ and ovulation to deviation $(52.4 \pm 5.2 \mathrm{~h}$ versus $71.8 \pm 4.1 \mathrm{~h}, \mathrm{P} \leq 0.05$ ) was shorter in cows than in heifers, respectively. After emergence no difference was found between cows and heifers. Consequently, after emergence data on cows and heifers were combined according to the dominant follicle (DF) and largest subordinate follicle (SF). DF and SF were identified at the same moment $(\mathrm{P}>0.05)$. The mean $( \pm \mathrm{SDM})$ number of small $(\leq 4 \mathrm{~mm}, 7.2 \pm 5.1)$ and medium $(4$ to $\leq 8 \mathrm{~mm}, 6.8 \pm 3.5)$ follicles were greater than large follicles $(\geq 8 \mathrm{~mm}, 0.6 \pm 0.5)$ from ovulation to 5 days after. DF diameter $(8.1 \pm 1 \mathrm{~mm})$ did not differ $(\mathrm{P}>0.05)$ from $\mathrm{SF}$ diameter $(7.6 \pm 0.9 \mathrm{~mm})$ at the moment of deviation (around 45 hours after emergence). DF and SF growth rates were similar until deviation, at this moment SF growth rate decreased while DF growth rate remained constant. In conclusion, the knowledge of the interval from ovulation to emergence and from ovulation to deviation, DF and SF diameter at deviation and DF and SF growth rate will be important in a fixed-time artificial insemination and in a multiple ovulation embryo transfer hormonal manipulation.

Key-words: conservation, dominant follicle, follicular dynamics, genetic resources. 


\section{INTRODUÇÃO}

As raças localmente adaptadas, como o Curraleiro Pé-Duro, são originárias dos bovinos trazidos durante a colonização a mais de 500 anos, as quais se adaptaram aos diferentes ecossistemas e condições climáticas existentes no Brasil (Fioravanti et al., 2011). A partir de sua introdução até os dias de hoje, a criação destas raças foi baseada em regime extensivo sem um manejo nutricional e sanitário adequado (Bianchini et al., 2006; Serrano et al., 2004). Durante os anos de seleção natural, os animais tornaram-se extremamente rústicos e resistentes ao clima seco, pastagens de baixa qualidade, altas temperaturas, doenças em geral, endoparasitas e ectoparasitas (Mariante \& Egito, 2002; Egito et al., 2002). A partir da metade do século 20, apesar de características desejáveis como resistência e adaptação a regiões de clima tropical seco, o número de animais da raça teve uma queda, ficando em torno de 5.000 (Fioravanti et al., 2011). Isto, provavelmente, devido à intensa seleção genética realizada em raças exóticas de clima temperado (Bos taurus) e nas raças zebuínas (Bos indicus), aliado a cruzamentos não planejados do Curraleiro Pé-Duro com estas.

No contexto de preservação e disseminação da raça, o uso de biotecnologias da reprodução, como a inseminação artificial em tempo fixo (IATF), a múltipla ovulação e transferência de embriões (MOTE) e a produção in vitro de embriões (PIVE), são fundamentais. Contudo, para uma eficiente manipulação hormonal do ciclo estral, o conhecimento da fisiologia reprodutiva é necessário. Estudos sobre a emergência (Adams et al., 1992, 1999) e divergência

(Ginther et al., 1997; Castilho et al., 2007) folicular em raças Bos taurus e Bos indicus já foram realizados, permitindo a aplicação prática destas biotecnologias em rebanhos comerciais (Bó et al., 2006; Sá Filho et al., 2013). 
O padrão do desenvolvimento folicular nos bovinos é caracterizado por ondas, geralmente de duas a três (Ginther et al., 1989; Figueiredo et al., 1997), em que um grupo de pequenos folículos antrais (4 mm), estimulados pelo hormônio folículo estimulante (FSH; Ginther et al., 1996; Driancourt, 2001), crescem em média três dias (emergência folicular). A partir deste momento o futuro folículo dominante (FD) emerge e aumenta sua capacidade de síntese de inibina e estradiol-17 (E2), fazendo um feed-back negativo ao FSH e os subordinados entram em atresia por consequência (divergência folicular; Ginther et al., 2001). Apesar deste padrão folicular e hormonal, existem algumas diferenças entre as raças Bos taurus e Bos indicus (Alvarez et al., 2000; Baruselli et al., 2007) que levam a necessidade de uma adequação da manipulação hormonal. Por isso é importante o estudo da fisiologia da reprodução da raça Curraleiro Pé-Duro, uma vez que se trata de uma raça localmente adaptada, sobre a qual não existem informações sobre estes eventos, que uma vez conhecidos aumentaram as chances de sucesso da IATF, MOTE e PIVE.

O objetivo do estudo foi caracterizar a dinâmica folicular durante a emergência e divergência folicular em novilhas e vacas da raça Curraleiro Pé-Duro criadas em um ambiente de clima tropical seco. 


\section{MATERIAIS E MÉTODOS}

\subsection{Local, Manejo Alimentar e Animais}

O experimento foi realizado na Fazenda Experimental Sucupira (15 $52^{\prime}-15^{\circ} 56^{\prime} \mathrm{S}$ $\left.48^{\circ} 00^{\prime}-48^{\circ} 02^{\prime} \mathrm{O}\right)$, Riacho Fundo, Brasil. A altitude no local varia de 1050 a 1250 metros, sendo o clima predominante o Koppen Aw, indicando inverno seco (umidade relativa pode chegar a 10\%) e verão chuvoso.

Foram utilizadas 11 vacas pluríparas, não lactantes, entre três e oito anos, e 11 novilhas com dois anos, com condição corporal média 3 (1- muito magra e 5- muito gorda; Wildman et al., 1982). Os animais foram mantidos durante todo experimento em pastagem (Brachiaria decumbens), com suplementação mineral e acesso a água ad libitum.

Todos os procedimentos descritos no trabalho foram aprovados pelo Comitê de Ética e Bem Estar Animal da Embrapa Recursos Genéticos e Biotecnologia, protocolo CEUA 02/2013.

\subsection{Sincronização do Estro e Avaliação Ultrassonográfica}

Previamente ao experimento, todos os animais foram submetidos a exame ginecológico que constava de palpação retal, avaliação ultrassonográfica (Mindray 2200 Vet, Shenzhen, China; equipado com probe transrectal de 7,5 MHz) e vaginoscopia, para determinar a ausência de doenças ou anormalidades no trato reprodutivo. 
O estro foi sincronizado com duas aplicações de D-Cloprostenol intramuscular (IM, 0,150 mg, $\mathrm{PGF}_{2 \alpha}$; Prolise ${ }^{\circledR}$, Tecnopec LTDA, São Paulo, Brasil) administradas com o intervalo de 11 dias. A partir do dia seguinte a segunda aplicação de $\mathrm{PGF}_{2 \alpha}$, os animais foram observados quanto à manifestação de estro três vezes ao dia com intervalo de 8 horas, por um período de 30 minutos com auxílio de rufião. Este procedimento de detecção do estro foi realizado até o momento da ovulação em cada fêmea. O momento do estro foi determinado quando uma fêmea permitiu a monta por parte do rufião ou de outra fêmea (Galina \& Orihuela, 2007).

No dia seguinte a segunda aplicação de $\mathrm{PGF}_{2 \alpha}$ também foi iniciada a avaliação ultrassonográfica ovariana (Mindray 2200 Vet, Shenzhen, China; equipado com probe transretal de 7,5 MHz), a cada oito horas (08:00 h, 16:00 h e as 24:00 h), até 5 dias após ovulação e uma vez ao dia nos dias seis e sete após ovulação. Sendo estas duas últimas avaliações realizadas para correta identificação do folículo dominante (FD). O momento da ovulação foi determinado após identificação do estro e futuro desaparecimento abrupto do FD (>10 mm) entre dois exames consecutivos $(8 / 8 \mathrm{~h})$ com formação subsequente de um corpo lúteo $(\mathrm{CL})$. Cada folículo maior de $3 \mathrm{~mm}$ e o CL foram monitorados diariamente e desenhados em uma ficha de dinâmica folicular, caracterizando o tamanho e localização no respectivo ovário. $\mathrm{O}$ diâmetro folicular foi determinado pela média de dois diâmetros perpendiculares entre eles.

A emergência folicular foi determinada pelo momento em que o futuro FD $(\geq 10$ $\mathrm{mm}$ ) tinha em torno de $4 \mathrm{~mm}$, em análise retrospectiva (Ginther et al., 1996). O FD foi identificado como sendo o maior folículo que atingiu diâmetro $\geq 10 \mathrm{~mm}$ e que era maior $2 \mathrm{~mm}$ que o maior folículo subordinado (FS). Já o início da divergência folicular foi definido como, o início da maior diferença na taxa de crescimento $(\mathrm{mm} / 8 \mathrm{~h})$ entre os dois maiores folículos em determinado exame, ou exame anterior, em que o FS atingiu seu máximo diâmetro (Ginther et al., 1996).

\subsection{Análise Estatística}


As análises dos dados foram realizadas com o auxílio do software estatístico gratuito R Core Team 2013 (R: A language and environment for statistical computing. R Foundation for Statistical Computing, Vienna, Austria) adotando-se como nível de significância $\mathrm{P} \leq 0,05$. Os dados foram normalizados para o momento da emergência ou para a divergência folicular. Os dados de tamanho folicular e taxa de crescimento foram analisados de acordo com o momento da emergência e da divergência, após normalização. Os efeitos principais dos exames sequenciais foram examinados para diferenças entre médias por $t$-tests. Foi utilizado o modelo linear generalizado (MLG) utilizando a distribuição gaussiana, no qual se verificou o efeito da categoria folicular, da hora e da interação folículo-hora no tamanho folicular e taxa de crescimento. A adequabilidade da distribuição normal (gaussiana) foi analisada pelos gráficos de envelopes simulados para os resíduos. Não havendo acomodação da distribuição normal clássica, mudava-se a função de ligação para log, inversa ou raiz quadrada. A taxa de crescimento folicular $(\mathrm{mm} / 8 \mathrm{~h}$ ou $\mathrm{mm} / 16 \mathrm{~h})$ em cada onda foi calculada pela razão entre a variação observada no diâmetro folicular e o número de intervalos de observação. Incluindo assim dados do primeiro dia em que o folículo foi observado até o dia do máximo diâmetro alcançado. Os dados foram apresentados como média \pm desvio padrão (DPM). 


\section{RESULTADOS}

As principais características foliculares no momento da emergência e divergência folicular na comparação vaca e novilha podem ser visualizadas na Tabela 3.1. A análise de regressão (gráficos não mostrados) e comparação de médias, não mostraram diferenças das características foliculares, com exceção do momento da emergência e divergência em relação à ovulação, sendo ambos mais precoces nas vacas $(\mathrm{P} \leq 0,05)$. Consequentemente, optou-se por unir os dados e comparou-se o desenvolvimento do folículo dominante (FD) versus o maior folículo subordinado (FS), normalizando os dados para emergência ou divergência. 
Tabela 3.1. Características foliculares na emergência e divergência (média \pm DPM) da primeira onda folicular em vacas e novilhas Curraleiras Pé-Duro.

\begin{tabular}{|c|c|c|}
\hline Características foliculares & Vaca $(\mathrm{n}=11)$ & Novilha $(\mathrm{n}=11)$ \\
\hline Intervalo estro-ovulação (horas) ${ }^{*}$ & $21,8 \pm 3$ & $21,4 \pm 1,4$ \\
\hline \multicolumn{3}{|l|}{ Início da emergência } \\
\hline Horas após ovulação* & $11,6 \pm 3,3^{b}$ & $20,3 \pm 2,5^{a}$ \\
\hline Número de folículos recrutados & $17,6 \pm 1,2$ & $15,3 \pm 0,9$ \\
\hline Tamanho do FD (mm) & $4,16 \pm 0,1$ & $4,17 \pm 0,1$ \\
\hline Tamanho do FS (mm) & $3,84 \pm 0,1$ & $3,81 \pm 0,1$ \\
\hline \multicolumn{3}{|l|}{ Início da divergência } \\
\hline Horas após ovulação* & $52,4 \pm 5,2^{b}$ & $71,8 \pm 4,1^{a}$ \\
\hline Horas após emergência & $40,7 \pm 4,4$ & $50,9 \pm 4,2$ \\
\hline Tamanho do FD (mm) & $7,9 \pm 0,2$ & $8,3 \pm 0,4$ \\
\hline Tamanho do FS (mm) & $7,3 \pm 0,2$ & $7,7 \pm 0,3$ \\
\hline \multicolumn{3}{|l|}{ Taxa de crescimento } \\
\hline FD antes da divergência $(\mathrm{mm} / 8 \mathrm{~h})$ & $0,63 \pm 0,06^{A}$ & $0,56 \pm 0,03^{A}$ \\
\hline FS antes da divergência $(\mathrm{mm} / 8 \mathrm{~h})$ & $0,61 \pm 0,05^{\mathrm{A}}$ & $0,53 \pm 0,03^{\mathrm{A}}$ \\
\hline FD depois da divergência $(\mathrm{mm} / 8 \mathrm{~h})$ & $0,49 \pm 0,02^{\mathrm{B}}$ & $0,47 \pm 0,06^{\mathrm{B}}$ \\
\hline FS depois da divergência $(\mathrm{mm} / 8 \mathrm{~h})$ & $-0,67 \pm 0,06^{C}$ & $-0,68 \pm 0,04^{C}$ \\
\hline
\end{tabular}

${ }^{a, b}$ Médias com letras diferentes na mesma linha diferem a um nível de significância de 5\%.

A,B,C Médias com diferentes letras sobrescritas para a mesma coluna dentro do mesmo parâmetro diferem a um nível de significância de $5 \%$.

*Hora $0=$ hora da ovulação.

$\mathrm{FD}=$ folículo dominante; FS = folículo subordinado.

O número de folículos pequenos $(\leq 4 \mathrm{~mm}, 7,2 \pm 5,1)$ e médios $(4 \mathrm{a} \leq 8 \mathrm{~mm}, 6,8 \pm$ 3,5) foi superior $(\mathrm{P} \leq 0,05)$ ao número de folículos grandes $(\geq 8 \mathrm{~mm}, 0,6 \pm 0,5)$ ao longo dos cinco dias após ovulação (Figura 3.1). Na análise houve efeito de grupo, tempo (dia) e grupo por tempo $(\mathrm{P}<0,0001)$, em que o número de folículos pequenos diminuiu em contraste com o número de folículos médios e grandes que aumentaram. 


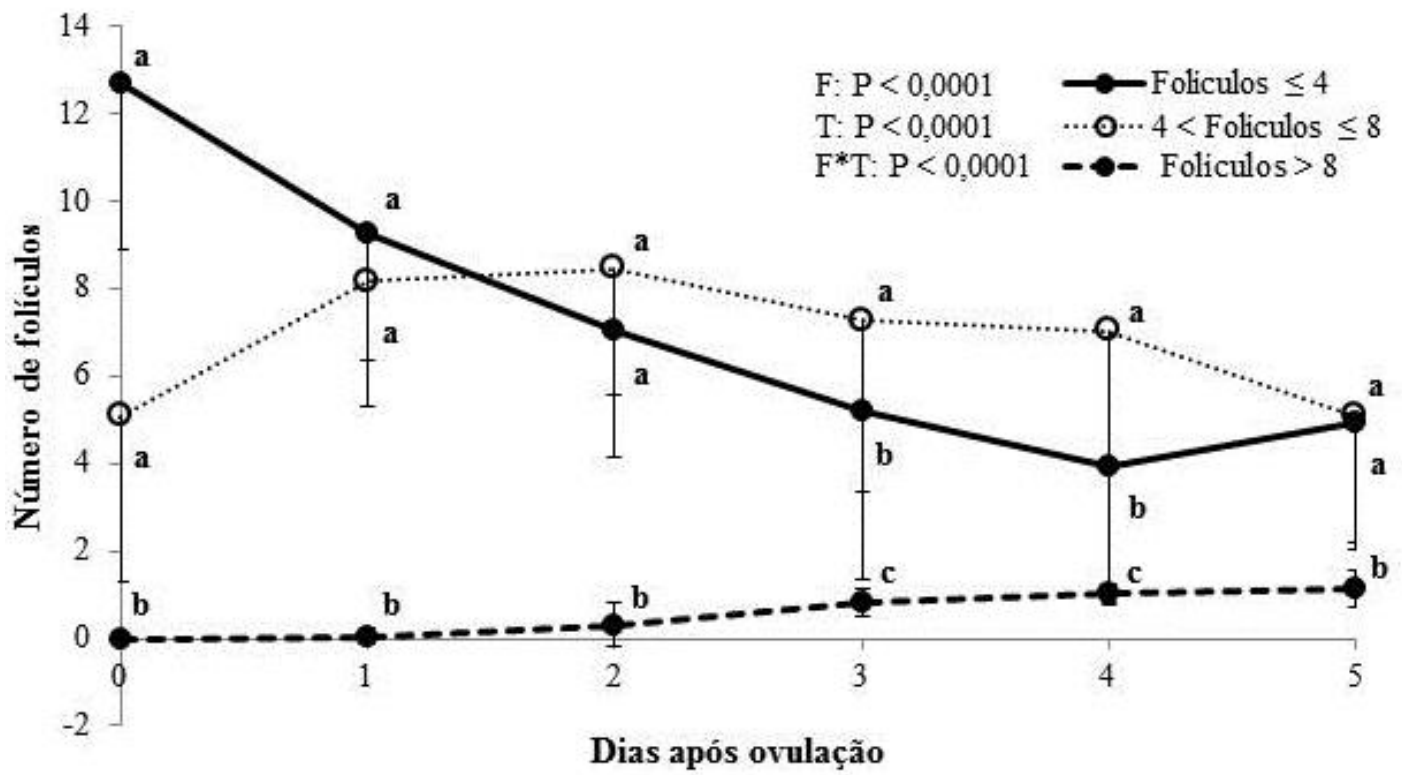

Figura 3.1. Número de folículos pequenos $(\leq 4 \mathrm{~mm})$, médios $(<4 \mathrm{a} \leq 8 \mathrm{~mm})$ e grandes $(>8 \mathrm{~mm})$ na raça Curraleiro Pé-Duro $(n=22)$ nos 5 primeiros dias após ovulação. F: efeito da categoria do folículo; T: efeito do tempo; $\mathrm{F}^{*} \mathrm{~T}$ : efeito da interação categoria por tempo. ${ }^{\mathrm{a}, \mathrm{b}, \mathrm{c}}$ Letras diferentes sobrescritas indicam diferença em um mesmo tempo (dia).

$\mathrm{O}$ crescimento folicular diário normalizado para o momento da emergência $(0 \mathrm{~h})$ pode ser visualizado na Figura 3.2. Houve efeito de folículo, tempo (hora) e interação folículo por tempo $(\mathrm{P}<0,0001)$ no tamanho folicular. No momento da emergência o tamanho do futuro FD $(4,1 \pm 0,4 \mathrm{~mm})$ foi similar ao futuro FS $(3,9 \pm 0,3 \mathrm{~mm})$, sendo que após 16 horas iniciou-se uma "aparente taxa de crescimento divergente" ao longo de quatro dias, em que o FS teve o crescimento interrompido e o FD continuou a crescer (Figura 3.2). O tamanho máximo do FD $(11,6 \pm 1,1 \mathrm{~mm})$ e FS $(7,6 \pm 0,8 \mathrm{~mm})$ foi alcançado quatro e dois dias após a emergência, respectivamente, tendo a divergência ocorrido em torno de 45,8 \pm 14,8 horas após a emergência. O momento da identificação (em torno de $4 \mathrm{~mm}$ ) do futuro FD e FS em relação a ovulação não diferiu para vacas $(13,8 \pm 3,5 \mathrm{~h}$ versus $16,7 \pm 3,5 \mathrm{~h})$ e novilhas $(22,5 \pm 2,8 \mathrm{~h}$ versus $24 \pm 3 \mathrm{~h})$, respectivamente. 


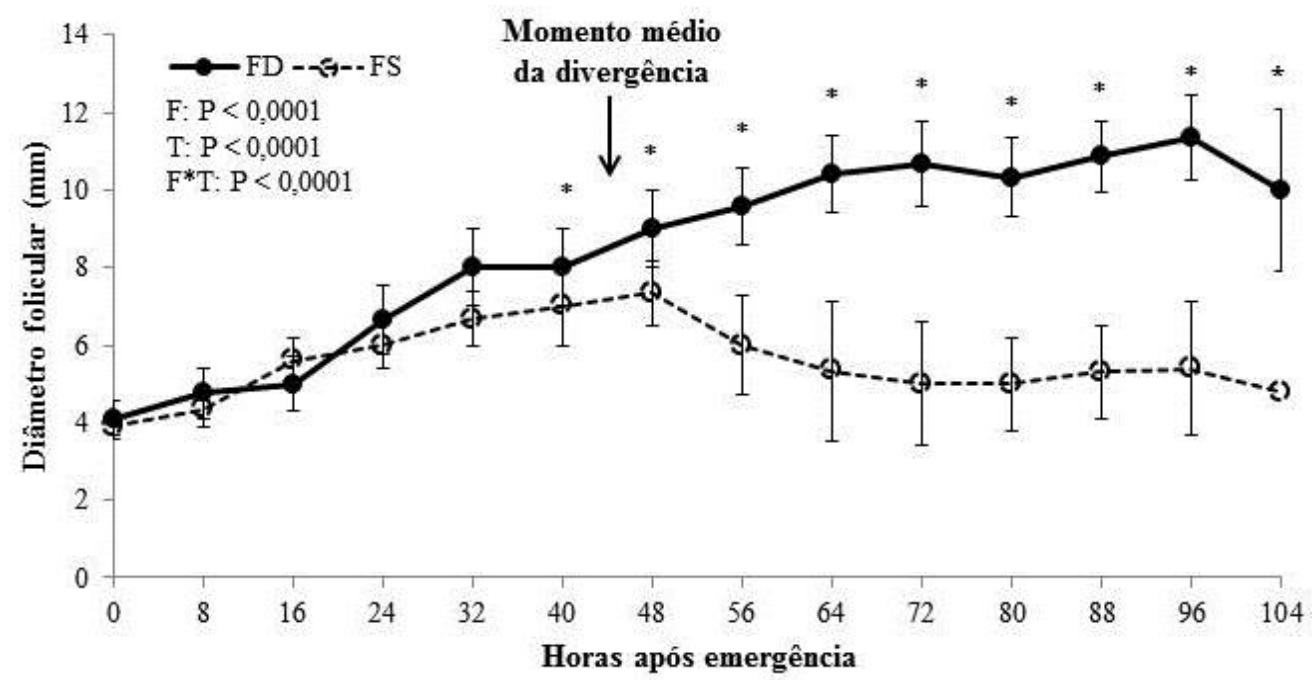

Figura 3.2. Comparação do desenvolvimento do FD e FS ao longo de 4 dias após normalização dos dados para a emergência. Percebe-se uma divergência gradual no crescimento do FD $(n=22)$ e FS $(n=$ 22) em que após o desvio o FS tem o crescimento interrompido e o FD continua a se desenvolver. F: efeito de categoria folicular; T: efeito do tempo; $\mathrm{F}^{*} \mathrm{~T}$ : efeito da interação tempo e categoria folicular. $\left(^{*}\right)$ Médias $( \pm \mathrm{DPM})$ com diferentes símbolos indicam diferenças $(\mathrm{P} \leq 0,05)$ entre o FD e FS em um mesmo tempo.

Quando o crescimento folicular foi normalizado para a hora da divergência $(0 \mathrm{~h})$, a diferença só foi observada após o desvio (Figura $3.3 \mathrm{~A})$. O tamanho do FD $(8,1 \pm 1 \mathrm{~mm})$ no momento da divergência naõ diferiu $(\mathrm{P}=0,09)$ do FS $(7,6 \pm 0,9 \mathrm{~mm})$. Houve efeito de folículo, tempo e interação folículo por tempo $(\mathrm{P}<0,0001)$ no tamanho folicular quando os dados foram avaliados normalizados para divergência.

A taxa de crescimento do FD não diferiu do FS até a hora da divergência, enquanto que após este momento a taxa do FD foi inversa a do FS, que foi negativa. As taxas de crescimento folicular do FD de 32 antes da divergência até 16 horas após divergência não diferiram, porém foram maiores do que 16 a 32 horas após a divergência (Figura 3.3 B). Enquanto que a taxa de crescimento do FS antes da divergência foi maior do que após ( $\mathrm{P} \leq 0,05)$. 

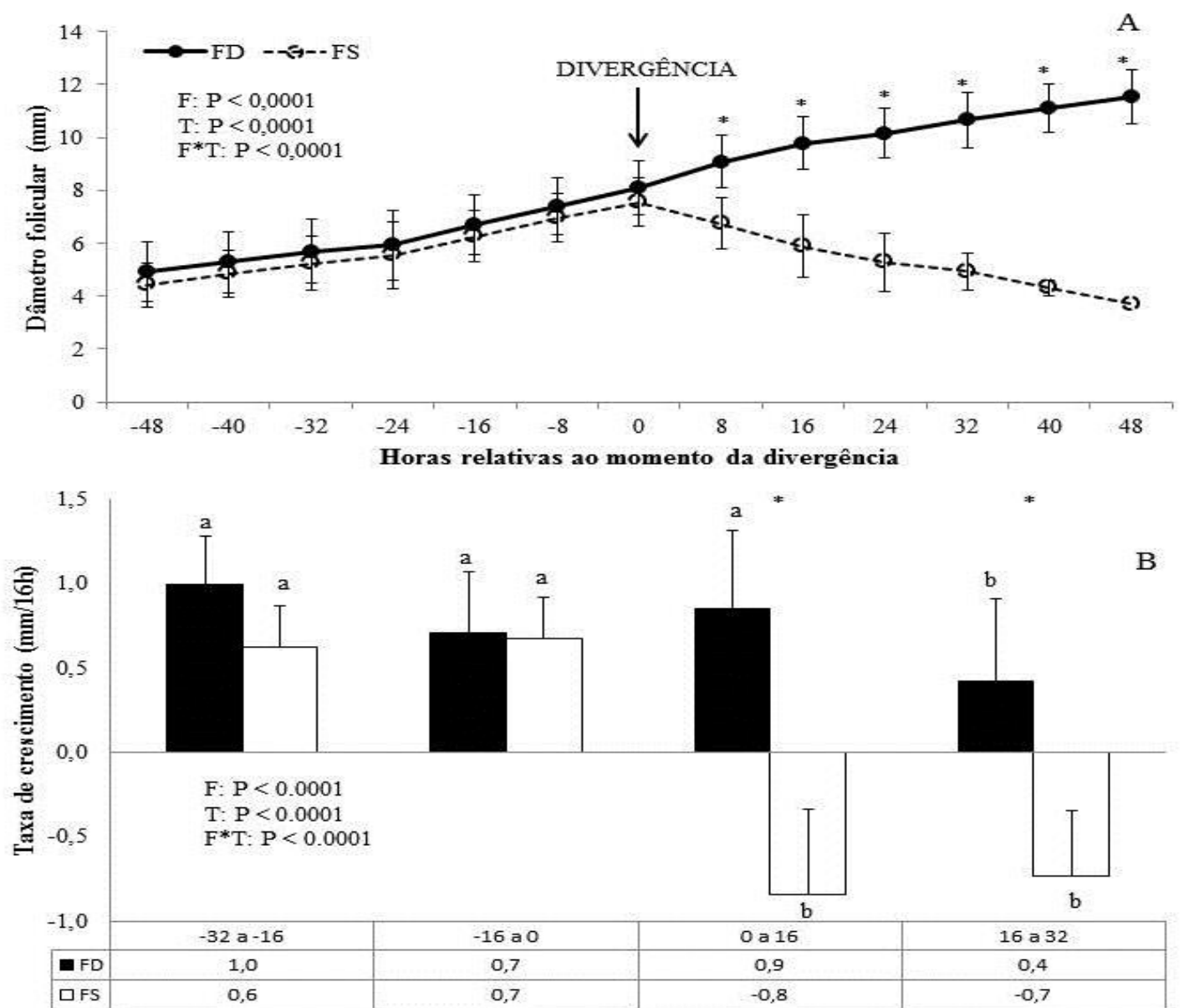

Figura 3.3 A e B. Médias ( \pm DPM) dos tamanhos (A) e taxa de crescimento (B) do FD $(n=22)$ e FS $(n=22)$ durante a primeira onda folicular após ovulação de acordo com o momento da divergência $(0 \mathrm{~h})$. F: efeito de categoria folicular; T: efeito do tempo; F*T: efeito da interação tempo e categoria folicular. $(*)$ Médias $( \pm \mathrm{DPM})$ com diferentes símbolos indicam diferenças $(\mathrm{P} \leq 0,05)$ entre o FD e FS em um mesmo tempo. $\left(^{\mathrm{a}, \mathrm{b}}\right)$ Médias $( \pm$ DPM) com diferentes letras indicam diferenças dentro da categoria folicular em diferentes tempos. 


\section{DISCUSSÃO}

O conhecimento dos eventos foliculares da primeira onda é importante para o aprimoramento da manipulação do ciclo estral no uso da IATF, MOTE e PIVE. Para tanto, este primeiro relato na raça servirá de base para o desenvolvimento de protocolos hormonais que venham a aperfeiçoar o uso das biotécnicas reprodutivas na preservação e expansão do Curraleiro Pé-Duro. A escolha da primeira onda para ser estudada foi baseada na menor variação de seu início em relação a segunda e/ou terceira e ao maior número de folículos recrutados (Baruselli et al., 2006; Ginther et al., 1989).

O intervalo estro-ovulação (21 horas) foi menor que o encontrado em estudo preliminar na raça (dados não publicados) que ficou entre 24,8 e 26 horas. Contudo, no estudo preliminar, a detecção do estro foi feita duas vezes por dia, enquanto que no presente trabalho a mesma foi feita três vezes. Pinheiro et al. (1998) trabalhando com novilhas e vacas Nelore também não encontraram diferença no intervalo estro-ovulação, 27,7 e 26,7 horas, respectivamente. Assemelhando-se aos dados do trabalho citado, Cavalieri et al. (1997) encontraram intervalo estro-ovulação em torno de 28 horas em vacas Nelore.

A emergência e divergência ocorreram em torno de 10 e 20 horas antes, respectivamente, nas vacas e novilhas. Figueiredo et al. (1997) e Sartorelli et al. (2005) não verificaram diferença entre novilhas e vacas Nelore no tempo entre a ovulação e a emergência e a divergência folicular. Entretanto, os referidos trabalhos realizaram avaliações uma ou duas vezes por dia, enquanto que no presente foram feitas três avaliações foliculares por dia.

O intervalo entre a ovulação e a emergência nas vacas Curraleiras Pé-Duro foi semelhante ao encontrado em novilhas Holandesas (0,3 dias; Adams et al., 1992), enquanto o 
intervalo entre ovulação e emergência nas novilhas foi semelhante ao observado em vacas e novilhas Nelore (0,9 dias; Sartorelli et al., 2005). Em contra partida Figueiredo et al. (1997) encontraram em fêmeas Nelore a emergência em torno de 1,5 dias após ovulação. Este maior intervalo observado pode ser devido à realização de uma avaliação folicular diária ao invés de duas ou três.

Trabalhos na raça Nelore e Holandesa relataram intervalo entre ovulação e divergência de 2,4 e 2,8 dias (Ginther et al., 1996; Fortune et al., 2001; Sartorelli et al., 2005; Gimenes et al., 2008), resultados estes, semelhantes aos encontrados para vacas e novilhas Curraleiras Pé-Duro, 2,1 e 2,9 dias, respectivamente.

O maior número de folículos pequenos após ovulação, em função do pico de FSH (Ginther et al., 1996), assemelha-se com outros estudos (Savio et al., 1988; Badinga et al., 1992; Alvarez et al., 2000). Em relação às raças Bos indicus trabalhos relatam um menor número de folículos pequenos nos animais Bos taurus (Segerson et al., 1984; Alvarez et al., 2000). Esta diferença pode estar associada a maior concentração de IGF-1 nos animais Bos indicus e de FSH nos animais Bos taurus (Simpson et al., 1994; Alvarez et al., 2000). Contudo, outros fatores de crescimento também podem estar envolvidos no número de folículos dentro do ovário, visto que Burns et al. (2005) não verificaram diferença na concentração de IGF-1 e $E_{2}$ entre vacas Holandesas com baixo e alto número de folículos. No mesmo estudo os autores relataram uma maior concentração de FSH nos animais com baixo número de folículos corroborando com outros trabalhos (Segerson et al., 1984; Alvarez et al., 2000).

O momento da identificação do futuro FD em relação ao maior FS não diferiu, assim como seus tamanhos. Em 14 fêmeas o FD foi identificado antes do FS e em 8 na mesma avaliação. Ginther et al. (1996) e Kullick et al. (1999) relataram em seus trabalhos que o FD foi identificado antes, e por isto teria maior desenvolvimento na emergência. No presente estudo foi adotada a identificação do FD em torno de 4 mm (emergência), já Ginther et al. (1996) verificaram o surgimento precoce do FD a partir de $3 \mathrm{~mm}$. Castilho et al. (2007) não encontraram diferenças no momento da identificação do FD e FS (aproximadamente 30 horas após ovulação) e seus respectivos tamanhos $(4,2 \mathrm{~mm}$ versus $3,7 \mathrm{~mm}, \mathrm{P}>0,05)$ em novilhas Nelore.

Quando os dados foram normalizados para o momento da divergência, observouse que não há diferença no crescimento até este ponto (Figura 3.3 A). Esta divergência gradual ao longo de dois dias após a emergência, provavelmente se deve a um reflexo das taxas de 
crescimento do FD e FS em vários períodos de avaliação e dentro de várias ondas. Os resultados assemelhan-se aos evidenciados por Ginther et al. (1996) trabalhando com vacas fêmeas taurinas, que também verificaram esta situação quando os dados foram normalizados para emergência e divergência folicular.

O tamanho do FD $(8,1 \pm 1 \mathrm{~mm})$ e FS $(7,6 \pm 0,9 \mathrm{~mm})$ no momento da divergência não diferiu $(\mathrm{P}=0,09)$, assim como em trabalhos com novilhas Holandesas $(7,7$ a $8,5 \mathrm{~mm}$ versus 7,2 a 7,3 mm, Ginther et al., 1997; Kullick et a., 1999) e novilhas Nelore (5,4 a 6,2 mm versus 5,4 a 5,9 mm, Sartorelli et al., 2005; Castilho et al., 2007; Gimenes et al., 2008), respectivamente. Os bovinos Bos taurus, inclusive o Curraleiro Pé-Duro, possuem FD maior que os animais Bos indicus na divergência. Esta diferença pode ser explicada em parte pelas concentrações de FSH e do fator de crescimento semelhante à insulina (IGF-1) nos diferentes grupos genéticos (Alvarez et al., 2000; Simpson et al., 1994). A função do IGF-1 parece estar envolvida na seleção folicular (Ginther et al., 2001), na qual mesmo em concentrações baixas de FSH, este fator de crescimento quando em abundância no líquido folicular, aumenta a responsividade do FD para o referido hormônio (revisado em Bo et al., 2003, Sartorelli et al., 2005). Da mesma forma, atua aumentando a sensibilidade das células foliculares ao LH (Spicer \& Echternkamp, 1995). A partir disto, Gimenes et al. (2008) relataram a hipótese de que a maior sensibilidade ao LH anteciparia a aquisição de seus receptores, e consequentemente o momento da divergência e ovulação de folículos menores nos animais Bos indicus, com maior concentração de IGF-1.

Em relação à taxa de crescimento, não houve diferença antes da divergência entre o FD e o FS, sendo que após, o FD manteve crescimento semelhante enquanto que o FS regrediu, assemelhando-se ao observado por Ginther et al. (2001) em novilhas Holandesas. Castilho et al. (2007) estudando novilhas Nelore verificaram que a taxa de crescimento do FD aumentou após a divergência, contudo isto pode ter sido reflexo da baixa taxa de crescimento antes da divergência $(0,45 \mathrm{~mm} / 12 \mathrm{~h})$. Outro estudo com novilhas Nelore também identificou taxa de crescimento do FD antes da divergência baixa $(0,5 \mathrm{~mm} / 12 \mathrm{~h})$, contudo a mesma não se alterou após este evento (0,6 mm/12h, Gimenes et al., 2008). Em fêmeas Holandesas a taxa de crescimento do FD parece ser maior (1,5-2,1 mm/d, Kullick et al., 1999; Ginther et al., 2001), que nas raças Bos indicus (0,45-1 mm/12h, Castilho et al., 2007; Gimenes et al., 2008) e na Curraleira (0,4-1 mm/16h). Esta diferença é refletida no diâmetro do FD no momento da divergência, sendo maior nos animais Bos taurus como já mencionado. 
Em conclusão, houve diferença entre vacas e novilhas apenas no momento da emergência e divergência folicular em relação à ovulação, o que deve ser considerado para futuros protocolos de IATF e MOTE, por exemplo. Após a emergência, ambas as categorias animais foram semelhantes quanto ao crescimento do FD e FS. Não houve diferença no tamanho do FD e FS na emergência e divergência, assim como o primeiro foi identificado em um mesmo momento que o segundo. $\mathrm{O}$ tamanho do FD na divergência foi semelhante ao encontrado em animais Bos taurus, assim como a taxa de crescimento também foi maior que nos animais Bos indicus. Os dados obtidos com a pesquisa servirão de base para as manipulações hormonais na obtenção de maior número de embriões e aumento nas taxas de prenhez. 


\section{AGRADECIMENTOS}

Os autores agradecem a CAPES pela bolsa estudantil, ao CNPq e a FAP-DF pelo suporte financeiro e a Rede Centro-Oeste de Pós-Graduação, Pesquisa e Inovação. 


\section{REFERÊNCIAS BIBLIOGRÁFICAS}

ADAMS, G.P. Comparative patterns of follicle development and selection in ruminants. Journal of Reproduction and Fertility Supplement, v. 54, p. 17-32, 1999.

ADAMS, G.P.; MATTERI, R.L.; KASTELIC, J.P. et al. Association between surges of folliclestimulating hormone and the emergence of follicular waves in heifers. Journal of Reproduction and Fertility, v. 94, p. 177-188, 1992.

ALVAREZ, P.; SPICER, L.J.; CHASE, C.C. et al. Ovarian and endocrine characteristics during an estrous cycle in Angus, Brahman, and Senepol cows in a subtropical environment. Journal of Animal Science, v. 78, p. 1291-1302, 2000.

BADINGA, L.; DRIANCOURT, M.A.; SAVIO, J.D. et al. Endocrine and ovarian responses associated with the first-wave dominant follicle in cattle. Biology of Reproduction, v. 47, p. 871-883, 1992.

BARUSELLI, P.S.; FILHO, M.S.F.; MARTINS, C.M. et al. Superovulation and embryo transfer in Bos indicus cattle. Theriogenology, v. 65, p. 77-88, 2006.

BARUSELLI, P.S.; GIMENES, L.U.; SALES, J.N.S. Reproductive physiology of Bos taurus and Bos indicus females. Animal Reproduction, v. 31, p. 205-211, 2007.

BIANCHINI, E.; CONCECPTA, M.; LUCCI, C.M. et al. Body traits associated with heat adaptation in naturalized Brazilian cattle breeds. Brazilian Agriculture Research, v. 41, p. 1443-1448, 2006.

BÓ, G.A.; BARUSELLI, P.S.; CHESTA, P.M. et al. The timing of ovulation and insemination schedules in superstimulated cattle. Theriogenology, v. 65, p. 89-101, 2006.

BÓ, G.A.; BARUSELLI, P.S.; MARTINEZ, M.F. Pattern and manipulation of follicular development in Bos indicus cattle. Animal Reproduction of Science, v. 78, p. 307-326, 2003. 
BURNS, D.S.; JIMENEZ-KRASSEL, F.; IRELAND, J.L.H. et al. Numbers of Antral Follicles During Follicular Waves in Cattle- Evidence for High Variation Among Animals, very high repeatability in individuals, and an inverse association with serum follicle-stimulating hormone concentrations. Biology of Reproduction, v. 73, p. 54-62, 2005.

CASTILHO, C.; GARCIA, J.M.; RENESTO, A. et al. Follicular dynamics and plasma FSH and progesterone concentrations during follicular deviation in the first post-ovulatory wave in Nelore (Bos indicus) heifers. Animal Reproduction of Science, v. 98, p. 189-196, 2007.

CAVALIERI, J.; RUBIO, I.; KINDER, J.E. et al. Synchronization of estrus and ovulation and associated endocrine changes in Bos indicus cows. Theriogenology, v. 47, p. 801-814, 1997.

DRIANCOURT, M.A. Regulation of ovarian follicular dynamics in farm animals. Implications for manipulation of reproduction. Theriogenology, v. 55, p. 1211-1239, 2001.

EGITO, A.A.; MARIANTE, A.S.; ALBUQUERQUE, M.S.M. The Brazilian Genetic Resources Conservation Program. Archives of Zootechnology, v. 51, p. 39-52, 2002.

FIGUEIREDO, R.A.; BARROS, C.M.; PINHEIRO, O.L. et al. Ovarian follicular dynamics in Nelore breed (Bos indicus) cattle. Theriogenology, v. 41, p. 1489-1505, 1997.

FIORAVANTI, M.C.S.; JULIANO, R.S.; COSTA, G.L. et al. Conservación del bovino Curraleiro: cuantificación del censo y caracterización de los criadores. Animal Genetic Resources, v. 48, p. 109-16, 2011.

FORTUNE, J.E.; RIVERA, G.M.; EVANS, A.C.O. et al. Differentiation of dominant versus subordinate follicles in cattle. Biology of Reproduction, v. 65, p. 648-654, 2001.

GALINA, C.S.; ORIHUELA A. The detection of estrus in cattle raised under tropical conditions: What we know and what we need to know. Hormonal Behaviour, v. 52, p. 32-38, 2007.

GIMENES, L.U.; SA FILHO, M.F.; CARVALHO, N.A. et al. Follicle deviation and ovulatory capacity in Bos indicus heifers. Theriogenology, v. 69, p. 852-858, 2008.

GINTHER, O.J.; BERGFELT, D.R.; BEG, M.A. et al. Follicle Selection in Cattle: Role of Luteinizing Hormone. Biology of Reproduction, v. 64, 197-205, 2001.

GINTHER, O.J.; KNOPF, L.; KASTELIC, J.P. Temporal associations among ovarian events in cattle during oestrous cycles with two and three follicular waves. Journal of Reproduction and Fertility, v. 87, p. 223-230, 1989.

GINTHER, O.J.; KOT, K.; KULLICK, L.J. et al. Emergence and deviation of follicles during the development of follicular waves in cattle. Theriogenology, v. 48, p. 75-87, 1997.

GINTHER, O.J.; WILTBANK, M.C.; FRICKE, P.M.; Gibbons, J.R.; Kot, K. Selection of the dominant follicle in cattle. Biology of Reproduction, v. 55, p. 1187-1194, 1996. 
KULLICK, L.J.; KOT, K.; WILTBANK, M.C. et al. Follicular and hormonal dynamics during the first follicular waves in heifers. Theriogenology, v. 52, p.913-921, 1999.

MARIANTE, A.S.; EGITO, A.A. Animal Genetic resources in Brazil: result of five centuries of natural selection. Theriogenology, v. 57, p. 223-235, 2002.

PINHEIRO, O.L.; BARROS, C.M.; FIGUEIREDO, R.A. et al. Estrous behavior and the estrusto-ovulation interval in Nelore cattle (Bos indicus) with natural estrus or estrus induced with prostaglandin F2 $\alpha$ or norgestomet and estradiol valerate. Theriogenology, v. 49, p. 667-681, 1998.

SÁ FILHO, M.F.; PENTEADO, L.; REIS, E.L. et al. Timed artificial insemination early in the breeding season improves the reproductive performance of suckled beef cows. Theriogenology, v. 79, p. 625-632, 2013.

SARTORELLI, E.S.; CARVALHO, L.M.; BERGFELT, D.R. et al. Morphological characterization of follicle deviation in Nelore (Bos indicus) heifers and cows. Theriogenology, v. 63, p. 2382-2394, 2005.

SAVIO, J.D.; KEENAN, L.; BOLAND, M.P. et al. Pattern of growth of dominant follicles during the oestrous cycle of heifers. Journal of Reproduction and Fertility, v. 83, p. 663-671, 1998.

SEGERSON, E.C.; HANSEN, T.R.; LIBBY, D.W. et al. Ovarian and uterine morphology and function in Angus and Brahman cows. Journal of Animal Science, v. 59, p. 1026-1046, 1984.

SERRANO, G.M.; EGITO, A.A.; MCMANUS, C. et al. Genetic diversity and population structure of Brazilian native bovine breeds. Brazilian Agriculture Research, v. 39, p. 543-549, 2004.

SIMPSON, R.B.; CHASE JR, C.C.; SPICER, L.J. et al. Effect of exogenous insulin on plasma and follicular insulin-like growth factor I, insulin-like growth factor binding protein activity, follicular estradiol and progesterone, and follicular growth in superovulated Angus and Brahman cows. Journal of Reproduction and Fertility, v. 102, p. 483-492, 1994.

SPICER, L.J.; ECHTERNKAMP, S.E. The ovarian insulin and insulin-like growth factor system with an emphasis on domestic animals. Domestic Animal Endocrinology, v. 12, p. 223-245, 1995.

WILDMAN, E.E.; JONES, G.M.; WAGNER, P.E. A dairy cow body condition scoring system and its relationship to selected production characteristics. Journal of Dairy Science, v. 65, p. 495-501, 1992. 


\section{CAPÍTULO 4}

\section{BASES PARA O DESENVOLVIMENTO DE PROTOCOLOS DE INSEMINAÇÃO ARTIFICIAL EM TEMPO FIXO NA RAÇA LOCALMENTE ADAPTADA CURRALEIRO PÉ-DURO}

Rodrigo Dorneles Tortorella ${ }^{\mathrm{a}, \mathrm{c}}$, Mairon Rocha Modesto ${ }^{\mathrm{b}}$, Jairo Pereira Neves ${ }^{\mathrm{a}}$, Alexandre Floriani Ramos $^{\mathrm{c}}$

a Programa de Pós-Graduação em Ciência Animal, Faculdade de Agronomia e Medicina Veterinária, Universidade de Brasília, UnB, Brasília, Distrito Federal, Brasil;

${ }^{\mathrm{b}}$ Faculdades Integradas da União Educacional do Planalto Central, FACIPLAC, Brasília, Distrito Federal, Brasil;

${ }^{\mathrm{c} E m b r a p a ~ R e c u r s o s}$ Genéticos e Biotecnologia, Cenargen, Brasília, Distrito Federal, Brasil; 


\section{RESUMO}

O objetivo do trabalho foi avaliar a resposta folicular e luteal de fêmeas da raça Curraleiro PéDuro frente à utilização de distintos protocolos para a inseminação artificial em tempo fixo. No experimento 1 , vacas cíclicas $(\mathrm{n}=12)$, não lactantes, pluríparas receberam um dispositivo intravaginal contendo $1 \mathrm{~g}$ de progesterona (P4) durante oito dias e $2 \mathrm{mg}$ de benzoato de estradiol (BE) intramuscular (IM) no momento da inserção do dispositivo (Dia 0). Na retirada do dispositivo as vacas receberam 0,150 $\mathrm{mg}$ de D-cloprostenol Sódico IM e foram separadas em três grupos. O grupo BE 8 recebeu $1 \mathrm{mg}$ de $\mathrm{BE} \mathrm{IM,} \mathrm{o} \mathrm{CE} 8$ recebeu $1 \mathrm{mg}$ de cipionato de estradiol (CE) IM e no Controle não foi aplicado indutor da ovulação. Todos os animais participaram de todos os tratamentos (crossover). O momento da ovulação foi mais precoce e mais concentrado nos animais do grupo BE 8. No experimento 2, vacas cíclicas $(\mathrm{n}=12)$, não lactantes, pluríparas receberam um dispositivo intravaginal contendo $1 \mathrm{~g}$ de $\mathrm{P} 4$ durante oito dias e $2 \mathrm{mg}$ de BE IM no momento da inserção do dispositivo (Dia 0). Na retirada do dispositivo as vacas receberam 0,150 mg de D-Cloprostenol Sódico IM e foram separadas em 2 grupos. O grupo da gonadotrofina coriônica equina (eCG) recebeu 300 UI no dia 8, enquanto que o Controle não. Não houve diferença nos parâmetros reprodutivos avaliados $(\mathrm{P}>0,05)$. Contudo, o eCG promoveu um aumento numérico de $3 \mathrm{ng} / \mathrm{ml}$ na concentração de P4. Em conclusão, o BE proporcionou melhor resultado como indutor da ovulação, enquanto que o eCG precisa ser testado em um maior número de animais com menor condição corporal para atestar seu efeito positivo ou não nestas condições.

Palavras-chave: BE, conservação, dinâmica folicular, CE e eCG. 


\section{ABSTRACT}

The objective was to evaluate the effects of two ovulatory inducers and equine chorionic gonadotropin (eCG) on follicular and luteal dynamics in a fixed-time AI protocol in locally adapted Curraleiro Pé-Duro cows. In Experiment 1, cyclic, non-lactating, multiparous cows ( $\mathrm{n}=$ 12), were given $2 \mathrm{mg}$ of estradiol benzoate (EB) intramuscular (IM) and a progestin intravaginal device containing $1 \mathrm{~g}$ of progesterone (P4) on Day 0. At device removal (Day 8) $0.150 \mathrm{mg}$ of sodium D-cloprostenol was administered IM and cows were assigned to three groups. EB 8 group received $1 \mathrm{mg}$ of EB IM and CE 8 group received $1 \mathrm{mg}$ of estradiol cypionate (CE) IM at device removal, while Control group did not receive any ovulatory inducer. All animals participated of all treatments (crossover). The interval from P4 removal to ovulation was shorter and less variable in EB 8 group $(\mathrm{P} \leq 0.05)$. In Experiment 2, cyclic, non-lactating, multiparous cows $(\mathrm{n}=$ 12) were given $2 \mathrm{mg}$ of EB IM and a progestin intravaginal device containing $1 \mathrm{~g}$ of P4 on Day 0. At device removal (Day 8) $0.150 \mathrm{mg}$ of sodium D-cloprostenol was administered IM and cows were assigned to two groups. eCG group received $300 \mathrm{UI}$ of equine chorionic gonadotropin at the device removal, while Control group did not. All animals participated of all treatments (crossover). No difference was found in the evaluated reproductive parameters $(\mathrm{P}>0.05)$. Despite that, eCG was able to increase numerically in $3 \mathrm{ng} / \mathrm{ml}$ the P4 concentration 10 and 15 days after ovulation. We concluded that EB was more effective as an ovulatory inducer while eCG needs to be tested in more animals with lower body condition score to prove its efficiency. Key-words: conservation, EB, eCG, CE and follicular dynamics. 


\section{INTRODUÇÃO}

O aumento da população humana levou a um cenário de crescente demanda por proteína animal. Ao mesmo tempo a terra utilizada para a pecuária vem diminuindo em área, sendo muitas vezes substituída pela agricultura (Anualpec, 2013). Sendo assim, a criação de um maior número de animais, em menor espaço, com menor custo e alta eficiência, torna-se imprescindível. Além disso, o cenário que aponta para mudanças climáticas aumentando a temperatrura global e alterando a distribuição pluvial ao longo do ano fortalece a necessidade da utilização de genótipos mais adaptados a condições hostis. Neste contexto as regiões de clima tropical seco ainda têm um grande potencial para ser explorado, e o uso de animais "localmente adaptados" pode ser uma alternativa de produção de carne com baixo investimento e de grande importância para a segurança alimentar.

Raças localmente adaptadas, como o Curraleiro Pé-Duro, possuem sua origem em raças ibéricas que chegaram a América do Sul durante o período de colonização (Fioravanti et al., 2011). A criação destes animais desde sua chegada foi baseada em sistema extensivo, com pouca ou nenhuma atenção dada ao manejo nutricional, sanitário e reprodutivo (Bianchini et al., 2006). Com isso, apresentam-se como animais rústicos e resistentes a ectoparasitas, endoparasitas, ao clima seco e as altas temperaturas (Egito et al., 2002; Mariante \& Egito, 2002). Apesar destas características desejáveis, sua população teve diminuição drástica (atualmente em torno de 5.000 animais) devido a cruzamentos desordenados principalmente com raças Zebuínas (Fioravanti et al., 2011).

A inseminação artificial em tempo fixo (IATF) pode ser útil na preservação e rápida multiplicação dessas raças, contribuindo para o melhor aproveitamento das regiões 
subutilizadas para a pecuária (clima tropical seco). A IATF tem grande impacto na eficiência reprodutiva de um rebanho, seja por estimular a ciclicidade no pós-parto, diminuir a ocorrência de ciclos curtos, possibilitar a inseminação sem a detecção de cio e/ou possibilitar uma taxa de prenhez em torno de 50\% no início da estação de monta (Baruselli et al., 2004; Sá Filho et al., 2013). A utilização desta biotécnica por parte de criadores dessas raças pode incrementar programas de conservação e melhoramento, uma vez que demandará maior organização e tecnificação das propriedades.

Os protocolos de IATF tem como base a utilização de fontes de progesterona (P4) e derivados do estradiol-17 (E2) para a sincronização de uma nova onda folicular (Baruselli et al., 2004). No final destes aplicam-se derivados da prostaglandina $\mathrm{F}_{2 \alpha}\left(\mathrm{PGF}_{2 \alpha}\right)$ levando a regressão do corpo lúteo (CL) e diminuição da concentração de P4 (Carvalho et al., 2008). A gonadotrofina coriônica equina (eCG) vem sendo usada, e com bons resultados (Sá Filho et al., 2010b, Sales et al., 2011), com o objetivo de estimular o crescimento folicular final, aumentando assim as taxas de ovulação (Sartori et al., 2001) e prenhez (Sá Filho et al., 2010a). Por último é necessário induzir a ovulação do folículo dominante (FD) e os derivados do E2, benzoato de estradiol (BE) e cipionato de estradiol (CE), tem sido utilizados com sucesso (Colazo et al., 2004; Martinez et al., 2005; Meneghetti et al., 2009; Sales et al., 2012).

Os protocolos hormonais de IATF, bem adaptados para as raças Bos taurus e Bos indicus, ainda não foram testados em raças locamente adapatas como o Curraleiro Pé-Duro. Ou seja, não existe conhecimento das respostas fisiológicas frente a manipulação hormonal nesses animais. Os objetivos deste trabalho foram caracterizar sua resposta: (1) ao protocolo base de sincronização da ovulação; (2) a diferentes indutores da ovulação; (3) e ao eCG. 


\section{MATERIAIS E MÉTODOS}

\subsection{Local}

Os experimentos foram realizados no Campo Experimental Sucupira, que faz parte da Embrapa Recursos Genéticos e Biotecnologia, Brasília-DF, Brasil (1552’-1556’S e 4800'$48^{\circ} 02^{\prime}$ O), na qual a altitude varia de 1050 a 1250 metros. O clima predominante é o Koppen Aw, indicando inverno seco (umidade relativa pode chegar a 10\%) e verão chuvoso.

Todos os procedimentos descritos no trabalho foram aprovados pelo Comitê de Ética e Bem Estar Animal da Embrapa Recursos Genéticos e Biotecnologia, protocolo CEUA $02 / 2013$.

\subsection{Experimento 1}

O objetivo do experimento foi avaliar a resposta folicular e luteal a dois indutores da ovulação em um protocolo de sincronização da ovulação a base de P4 e BE em vacas Curraleiras Pé-Duro.

Previamente ao experimento, todos os animais foram submetidos a exame ginecológico que constava de palpação retal, avaliação ultrassonográfica (Mindray 2200 Vet, Shenzhen, China; equipado com probe transrectal de 7,5 MHz) e vaginoscopia, para determinar a 
ausência de doenças ou anormalidades no trato reprodutivo. Foram utilizadas 12 vacas Curraleiras Pé-Duro cíclicas, pluríparas, não lactantes (último parto a 6 meses), entre 3 e 8 anos e com condição corporal (CC) média 3 (1- muito magra e 5- muito gorda; Wildman et al., 1982). Os animais foram mantidos durante todo experimento (março a junho, estação das águas) em pastagem (Brachiaria decumbens), com suplementação mineral e acesso a água ad libitum.

Os animais foram divididos em três grupos: BE 8, CE 8 e Controle, em um delineamento experimental em que todos participaram de todos os tratamentos (crossover). Entre cada réplica, após a última avaliação luteal, as vacas passaram por um repouso de 15 dias para luteólise e início de nova onda. Todos os animais receberam um dispositivo intravaginal por 8 dias contendo $1 \mathrm{~g}$ de P4 (Sincrogest ${ }^{\circledR}$, Ouro Fino, Cravinhos, São Paulo, Brasil) e 2 mg de BE intramuscular (IM, Gonadiol ${ }^{\circledR}$, Intervet Schering, Cotia, São Paulo, Brasil) no momento da inserção do dispositivo (Dia 0). No momento da retirada do dispositivo (Dia 8) foram aplicadas 0,150 mg de D-Cloprostenol Sódico IM ( $\mathrm{PGF}_{2 \alpha}$; Prolise ${ }^{\circledR}$, Tecnopec LTDA, São Paulo, Brasil) e os animais divididos em 3 grupos (Figura 4.1). Nos grupos BE $8(n=12)$ e CE $8(n=12)$ foi aplicado $1 \mathrm{mg}$ de BE e 1mg de CE (E.C.P. ${ }^{\circledR}$; Pfizer Saúde Animal, São Paulo, SP, Brasil) IM no dia da retirada da $\mathrm{P} 4$, respectivamente, enquanto que no grupo Controle $(\mathrm{n}=12)$ não foi aplicado nenhum indutor da ovulação. 


\section{Grupo Controle}

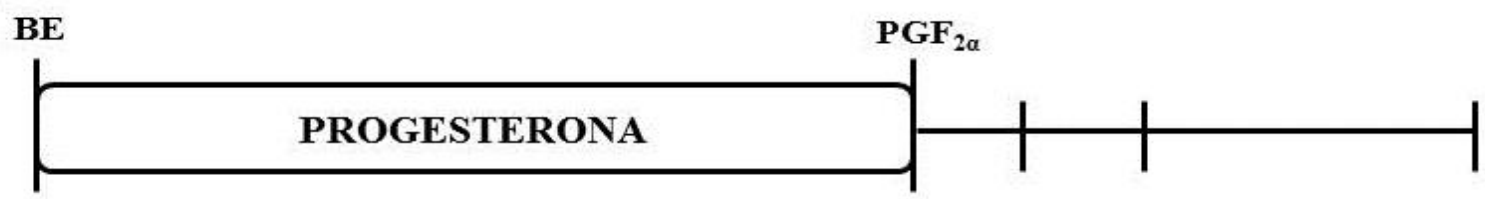

\section{Grupo BE 8}

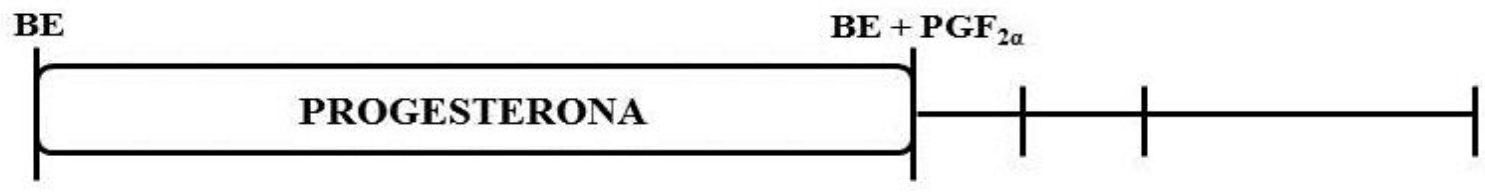

\section{Grupo CE 8}

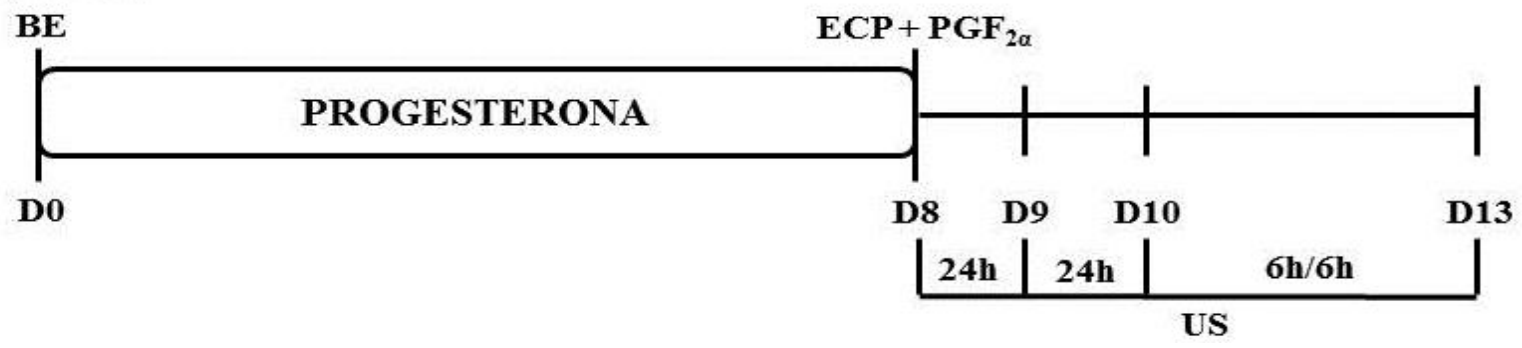

Figura 4.1. Delineamento experimental. Dia 0 (D0): administração de $2 \mathrm{mg}$ IM de BE e inserção de dispositivo vaginal com $1 \mathrm{~g}$ de P4. Dia 8 (D8): retirada da P4 e aplicação do D-Cloprostenol Sódico (0,150 mg, IM; Controle). Grupo BE 8: semelhante ao Controle com adição de $1 \mathrm{mg}$ de BE IM no dia 8. Grupo CE 8: semelhante ao Controle com adição de $1 \mathrm{mg}$ de CE IM no dia 8. Exames ultrassonográficos foram realizados uma vez ao dia entre os dias $8 \mathrm{e}$ 10 e após a cada 6 horas até a ovulação ou dia 13 (D13).

O crescimento folicular foi acompanhado com auxílio de um equipamento de ultrassom (Mindray 2200 Vet, Shenzhen, China; equipado com probe transretal de 7,5 MHz) a partir do dia oito (D8) a cada 24 horas até o dia 10 (D10). A partir desse momento, o FD foi avaliado a cada seis horas até a identificação da ovulação. O momento da ovulação foi determinado após desaparecimento do FD (> $10 \mathrm{~mm}$ ) entre dois exames consecutivos, seguido pela formação de um CL em seu local.

O volume do CL foi mensurado 5, 10 e 15 dias após ovulação utilizando a fórmula $\mathrm{V}=4 / 3 \times \pi \times \mathrm{R}^{3}$, na qual $\mathrm{R}=(\mathrm{Da} / 2+\mathrm{Db} / 2) / 2$ e $\mathrm{Da}$ e $\mathrm{Db}$ são os diâmetros perpendiculares do CL. Na existência de uma cavidade no CL, seu volume foi subtraído do volume total. Imediatamente após a avaliação do CL, amostras de sangue foram coletadas da veia jugular para análise de P4 em tubos de $9 \mathrm{ml}$ sem anticoagulante (Vacutainer ${ }^{\circledR}$, Beckton \& Dickson, Brasília, Brazil). Após coleta os tubos foram mantidos a $4^{\circ} \mathrm{C}$ por $10-15$ minutos e então centrifugados a 
$1500 \mathrm{x}$ g por 20 minutos. Subsequentemente, o soro foi removido e armazenado a $-20^{\circ} \mathrm{C}$ até análise da concentração de P4. A concentração de P4 foi determinada utilizando um Kit de radioimunoensaio (RIA) de fase sólida (Coat-a-Count DPC, Diagnostic Products Corporation, Los Angeles, CA, USA). A sensibilidade e o coeficiente de variação intra-ensaio foram 0,02 $\mathrm{ng} / \mathrm{ml}$ e $2,8 \%$, respectivamente.

\subsection{Experimento 2}

Neste experimento o objetivo foi avaliar o efeito do eCG na resposta folicular e luteal em vacas Curraleiras Pé-Duro.

Previamente ao experimento, todos os animais foram submetidos a exame ginecológico semelhante ao realizado no Experimento 1. Foram utilizadas 12 vacas Curraleiras Pé-Duro pluríparas, não lactantes (último parto a seis meses), entre três e oito anos e com condição corporal média 3 (1- muito magra e 5- muito gorda; Wildman et al., 1982). Os animais foram mantidos durante todo experimento (agosto a outubro) em pastagem (Brachiaria decumbens), com suplementação mineral e acesso a água ad libitum. O estudo foi desenvolvido durante o período da seca, sendo esses meses caracterizados pela baixa oferta e qualidade de forragem.

Os animais foram divididos em dois grupos: eCG e Controle, em um delineamento experimental em que todos os animais participaram de todos os tratamentos (crossover). Entre cada réplica as vacas passaram por um repouso de 15 dias para luteólise e início de nova onda. Todos os animais receberam um dispositivo intravaginal por oito dias contendo $1 \mathrm{~g}$ de P4 (Sincrogest $^{\circledR}$, Ouro Fino, Cravinhos, São Paulo, Brasil) e 2 mg de BE IM (Gonadiol ${ }^{\circledR}$, Intervet Schering, Cotia, São Paulo, Brasil) no momento da inserção do dispositivo (Dia 0). No momento da retirada do dispositivo (Dia 8) foram aplicadas 0,150 mg de D-cloprostenol códico ( $\mathrm{PGF}_{2 \alpha}$; Prolise $^{\circledR}$, Tecnopec LTDA, São Paulo, Brasil) e $1 \mathrm{ml}$ de BE IM e os animais divididos em 2 grupos (Figura 4.2). O grupo eCG $(\mathrm{n}=12)$ recebeu $400 \mathrm{UI}$ de eCG (Folligon ${ }^{\circledR}$, Intervet Schering, Cotia, São Paulo, Brasil) IM no dia 8 (D8) e o grupo Controle $(n=12)$ não recebeu eCG. 


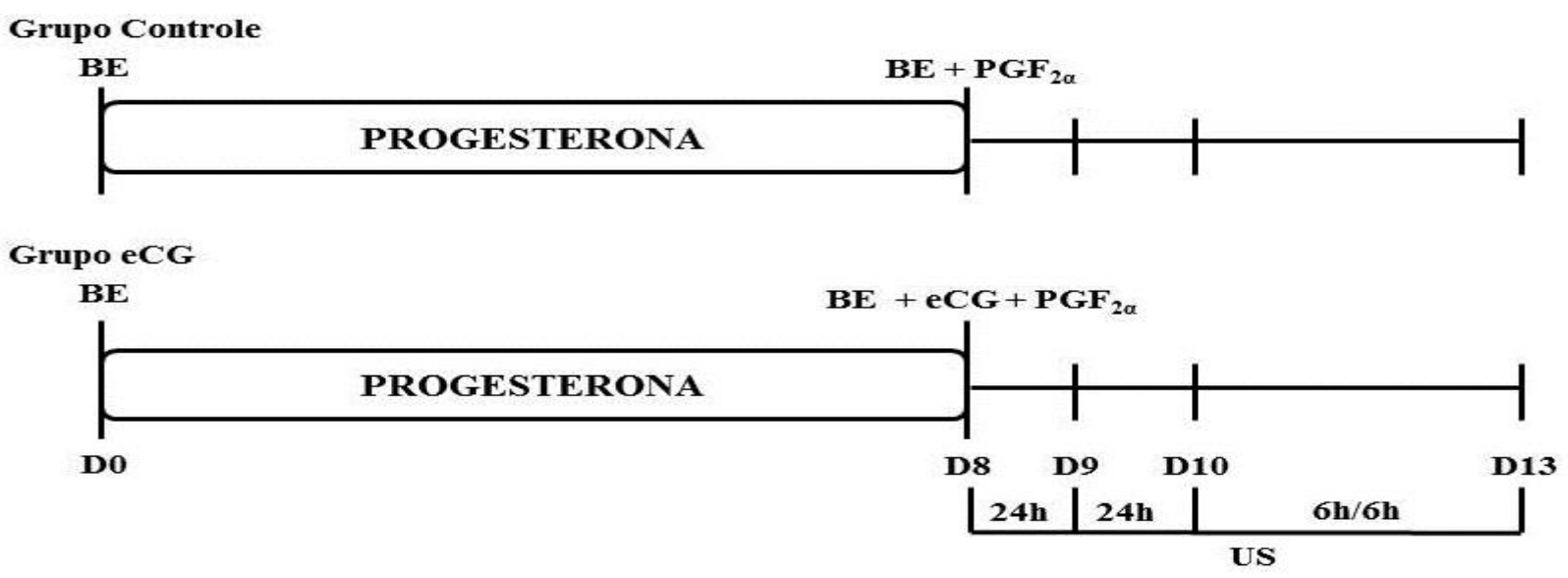

Figura 4.2. Delineamento experimental. Dia 0 (D0): administração de $2 \mathrm{mg}$ IM de BE e inserção de dispositivo vaginal com $1 \mathrm{~g}$ de P4. Dia 8 (D8): retirada da P4, aplicação do D-Cloprostenol Sódico (0,150 mg, IM) e $1 \mathrm{mg}$ de BE IM (Controle). Grupo eCG: semelhante ao Controle com adição 400 UI de eCG IM. Exames ultrassonográficos foram realizados uma vez ao dia entre os dias 8 e 10 e após a cada 6 horas até ovulação ou dia 13 (D13).

Todo a metodologia utilizada para a verificação do desenvolvimento folicular, luteal e concentração de P4 foi idêntica a realizada no Experimento 1.

\subsection{Análise estatística}

Os dados da dinâmica folicular foram analisados utilizando-se um modelo de análise para dados repetidos (MIXED model) sendo determinados os efeitos principais, grupo e dia, assim como sua interação. A diferença do diâmetro folicular a cada dia entre os distintos grupos foi determinada pelo "estimate statement". Os dados de volume de CL e concentração de P4 foram analisados por ANOVA utilizando-se os Modelos Lineares Gerais (MLG), e a multicomparação entre os distintos grupos realizada por least square means (LSMEANS). A distribuição dos dados foi testada para normalidade utilizando o teste de Shapiro-Wilk e normalizadas quando necessário. A variável categórica binomial (ovulação) foi analisada pelo PROC CATMOD e a multi-comparação entre grupos realizada por meio de contrastes. Todas as análises foram realizadas com o auxílio do programa estatístico SAS adotando-se como nível de significância $\mathrm{P} \leq 0,05$. Os dados foram apresentados como média \pm erro padrão da média (EPM). 


\section{RESULTADOS}

\subsection{Experimento 1}

$\mathrm{O}$ protocolo base, iniciando com $\mathrm{P} 4$ e $\mathrm{BE}$, foi eficiente em estimular a presença do FD maior que $8 \mathrm{~mm}$ após a retirada da P4 em 83,33\% (10/12) dos animais nos grupos Controle, BE 8 e CE $8(\mathrm{P}>0,05)$. As vacas sem $\mathrm{FD}$ após a retirada da $\mathrm{P} 4$ foram removidas da análise estatística. Houve efeito no crescimento folicular ao longo das avaliações $(\mathrm{P} \leq 0,05)$, entretanto os grupos não diferiram quanto a tamanho do FD, folículo ovulatório (FO) e taxa de ovulação (TO, Tabela 4.1).

Tabela 4.1. Efeito do BE e CE em um protocolo de IATF no diâmetro do folículo dominante (D8), folículo ovulatório (FO), tempo para ovulação (TOV) e taxa de ovulação (TO).

Diâmetro do folículo dominante $(\mathrm{mm})$

\begin{tabular}{llllll}
\cline { 2 - 4 } Grupos & D8 $(\mathrm{n}=10)$ & $\mathrm{D} 10(\mathrm{n}=10)$ & FO $(\mathrm{n})^{\mathrm{c}}$ & TOV $(\mathrm{h})$ & TO,n $(\%)$ \\
\hline Controle & $9,6 \pm 0,6$ & $12,1 \pm 0,7$ & $13,7 \pm 0,6(9)$ & $93 \pm 6^{\mathrm{a}}$ & $9 / 10(90)$ \\
BE 8 & $10,8 \pm 0,6$ & $12,1 \pm 0,6$ & $12,3 \pm 0,8(7)$ & $57 \pm 44^{\mathrm{b}}$ & $7 / 10(70)$ \\
CE 8 & $9 \pm 0,6$ & $10,8 \pm 0,8$ & $13,8 \pm 0,8(5)$ & $84 \pm 55^{\mathrm{a}}$ & $5 / 10(50)$
\end{tabular}

Os dados foram apresentados como média $\pm(E P M)$. Houve efeito do dia $(\mathrm{P}<0,001)$ no crescimento do folículo dominante, mas não entre grupos.

TOV: após retirada da $\mathrm{P} 4$.

${ }^{\mathrm{a}, \mathrm{b}}$ Médias com letras diferentes na mesma coluna diferem $(\mathrm{P} \leq 0,05)$.

${ }^{\mathrm{c}}$ As vacas com FD que não ovularam foram excluídas da análise. 
O tempo para ovulação (TOV) foi menor no grupo BE $8(\mathrm{P} \leq 0,05)$, além de ter proporcionado maior sincronia das mesmas (Figura 4.3). Entre os grupos Controle e o CE 8 não houve diferença no tempo para ovulação e sincronia das mesmas.

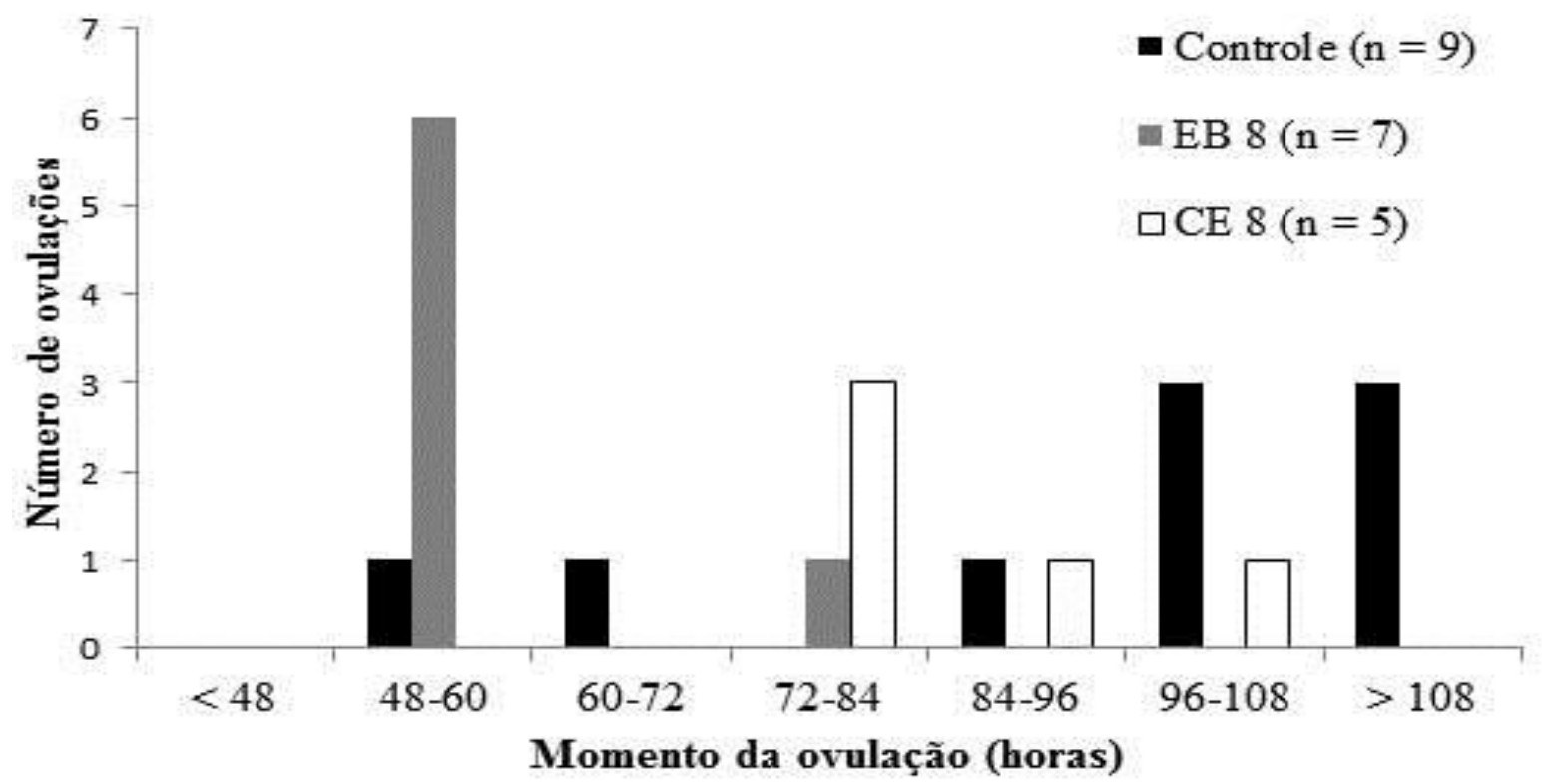

Figura 4.3. Distribuição das ovulações após a retirada da P4 no grupos Controle, BE 8 e CE 8.

Vacas com concentração de P4 abaixo de $1 \mathrm{ng} / \mathrm{ml} 5$ dias após a ovulação foram excluídas da análise. Duas vacas com concentrações outliers, uma do grupo Controle e uma do CE 8, foram excluídas da análise para evitar um resultado superestimado. As médias do volume do CL e concentração de P4 nos grupos Controle, BE 8 e CE 8 aos 5, 10 e 15 dias após a ovulação podem ser visualizadas na Tabela 4.2. Houve um crescimento no volume luteal e na concentração de $\mathrm{P} 4$ ao longo dos dias avaliados, porém os grupos não diferiram entre si ( $\mathrm{P}>$ $0,05)$. 
Tabela 4.2. Volume luteal $\left(\mathrm{mm}^{3}\right)$ e concentração de P4 (ng/ml) 5, 10 e 15 dias após ovulação em protocolo de IATF com aplicação de BE (BE 8) ou CE (CE8) como indutores da ovulação.

Dias após ovulação

\begin{tabular}{lllll} 
Parâmetros & Grupos & 5 & 10 & 15 \\
\hline & Controle $(\mathrm{n}=9)$ & $2.710 \pm 378$ & $4.779 \pm 500$ & $5.020 \pm 485$ \\
Volume luteal $\left(\mathrm{mm}^{3}\right)$ & BE 8 $(\mathrm{n}=7)$ & $3.514 \pm 129$ & $4.485 \pm 521$ & $4.611 \pm 363$ \\
& CP 8 $(\mathrm{n}=5)$ & $3.436 \pm 544$ & $5.780 \pm 495$ & $4.800 \pm 347$ \\
& Controle $(\mathrm{n}=7)^{\mathrm{a}}$ & $3 \pm 0,6$ & $6,4 \pm 0,5$ & $7,6 \pm 0,5$ \\
Concentração de $\mathrm{P}_{4}(\mathrm{ng} / \mathrm{ml})$ & $\mathrm{BE} \mathrm{8}(\mathrm{n}=6)^{\mathrm{b}}$ & $3,9 \pm 0,3$ & $5,5 \pm 0,4$ & $6,8 \pm 0,6$ \\
& $\mathrm{CP} 8(\mathrm{n}=4)^{\mathrm{c}}$ & $2,9 \pm 0,2$ & $5,5 \pm 0,5$ & $5,1 \pm 1,2$ \\
\hline
\end{tabular}

Os dados foram apresentados como média $\pm(\mathrm{EPM})$. Houve efeito do dia $(\mathrm{P}<0,001)$ no volume do CL e concentração de P4, mas não entre grupos.

${ }^{\mathrm{a}}$ Duas vacas foram excluídas da análise, uma por ter concentração de P4 menor que $1 \mathrm{ng} / \mathrm{ml} 5$ dias após ovulação e outra por ter uma concentração de $\mathrm{P} 4$ outlier.

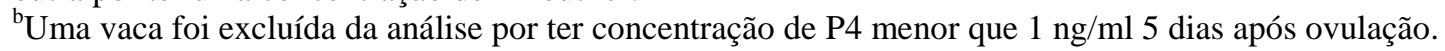

${ }^{c}$ Uma vaca foi excluída da análise por ter uma concentração de P4 outlier.

\subsection{Experimento 2}

O protocolo base, com P4 e BE, foi eficiente em estimular a presença de um FD maior que 8 mm após a retirada da P4 em 75\% (9/12) e 83,33\% (10/12) dos animais nos grupos Controle e eCG, respectivamente $(\mathrm{P}>0,05)$. As vacas sem $\mathrm{FD}$ após a retirada da $\mathrm{P} 4$ foram removidas da análise estatística. Houve efeito do dia e grupo $(\mathrm{P}<0,01)$, mas não houve interação grupo por dia no FD, FO, TOV e TO (Tabela 4.3). 
Tabela 4.3. Efeito do eCG em protocolo de IATF no diâmetro do folículo dominante (D8), folículo ovulatório (FO), tempo para ovulação (TOV) e taxa de ovulação (TO).

\begin{tabular}{llllll}
\hline & \multicolumn{2}{c}{ Diâmetro do folículo dominante $(\mathrm{mm})$} & \\
\cline { 2 - 4 } Grupos & D8 (n) & D10 (n) & FO (n) ${ }^{\text {a }}$ & TOV (h) & TO, n (\%) \\
\hline Controle & $8,4 \pm 0,4(9)$ & $10,2 \pm 0,5(9)$ & $10,9 \pm 0,4(6)$ & $68 \pm 94$ & $6 / 9(66,67)$ \\
eCG & $8,9 \pm 0,2(10)$ & $10 \pm 0,3(10)$ & $11,4 \pm 0,3(8)$ & $63 \pm 6$ & $8 / 10(80)$ \\
\hline
\end{tabular}

Os dados foram apresentados como média $\pm(E P M)$. Houve efeito do dia $(\mathrm{P}<0,001)$ no crescimento do FD, mas não entre grupos.

TOV: após retirada da $\mathrm{P} 4$.

${ }^{a}$ As vacas com FD que não ovularam foram excluídas da análise.

Uma vaca com volume luteal outlier do grupo Controle foi excluída da análise para evitar um resultado superestimado. As médias do volume do CL e concentração de P4 nos grupos Controle e eCG aos 5, 10 e 15 dias após a ovulação podem ser visualizadas na Tabela 4.4. Houve crescimento no volume luteal e na concentração de $\mathrm{P} 4$ ao longo dos dias avaliados (P < 0,001), mas não ocorreu interação entre grupo e dia para os parâmetros avaliados $(P>0,05)$.

Tabela 4.4. Volume luteal $\left(\mathrm{mm}^{3}\right)$ e concentração de $\mathrm{P} 4(\mathrm{ng} / \mathrm{ml})$ 5, 10 e 15 dias após ovulação em protocolo de IATF sem (Controle) e com aplicação de eCG no dia da retirada da P4.

\section{Dias após ovulação}

\begin{tabular}{lllll} 
Parâmetros & Grupos & 5 & 10 & 15 \\
\hline \multirow{2}{*}{ Volume luteal $\left(\mathrm{mm}^{3}\right)$} & Controle $(\mathrm{n}=5)^{\mathrm{a}}$ & $2.344 \pm 732$ & $4.521 \pm 989$ & $2.284 \pm 301$ \\
& eCG $(\mathrm{n}=8)$ & $2.310 \pm 455$ & $4.452 \pm 655$ & $3.767 \pm 525$ \\
& Controle $(\mathrm{n}=6)$ & $3 \pm 0,7$ & $5,2 \pm 1$ & $5,4 \pm 0,6$ \\
Concentração de P4 $(\mathrm{ng} / \mathrm{ml})$ & eCG $(\mathrm{n}=8)$ & $4,1 \pm 0,8$ & $8,5 \pm 1,3$ & $8,5 \pm 0,8$ \\
\hline
\end{tabular}

Os dados foram apresentados como média $\pm(\mathrm{EPM})$. Houve efeito do dia $(\mathrm{P}<0,001)$ no volume do $\mathrm{CL}$, mas não entre grupos $(\mathrm{P}>0,05)$.

${ }^{a}$ Uma vaca foi excluída da análise, por apresentar volume luteal outlier, para evitar um resultado superestimado. 


\section{DISCUSSÃO}

Por nosso conhecimento, este foi o primeiro trabalho que analisou a resposta folicular e luteal a protocolos de IATF em vacas da raça Curraleiro Pé-Duro. Os achados principais do trabalho foram que o BE como indutor da ovulação propiciou melhor sincronia das ovulações, mas o eCG não foi capaz de estimular o desenvolvimento do FD e consequentemente do CL.

Independentemente do experimento, os protocolos a base de P4, BE e $\mathrm{PGF}_{2 \alpha}$ sincronizaram o crescimento do FD em aproximadamente $80 \%$ dos animais. O protocolo foi considerado eficiente, quando, o FD após a retirada da P4 possuía tamanho superior a 8,5 mm, tamanho que caracteriza a divergência folicular (divergência folicular, Ginther et al., 1997). Este resultado foi inferior ao observado por outros trabalhos que verificaram entre 4,7\% e 6,7\% o índice de animais que não iniciaram nova onda ou não tinham FD na retirada da P4 (Martinez et al., 2005; Sales et al., 2012). O prolongamento da permanência da P4 de oito para nove dias poderá melhorar este índice, aumentando o tamanho do FD (Colazo et al., 2003) e consequentemente, as taxas de ovulação e prenhez (Perry et al., 2007; Sá Filho et al., 2010a).

No Experimento 1, não houve diferença no tamanho do FO entre os três grupos, tendo os mesmos alcançado tamanho satisfatório, acima de $12 \mathrm{~mm}$. Sartori et al. (2001) e Gimenes et al. (2008) relatam que a capacidade ovulatória está em parte relacionada ao tamanho do FO, sendo esta adquirida por completo a partir de $12 \mathrm{~mm}$ e $10 \mathrm{~mm}$ em fêmeas Bos taurus e Bos indicus, respectivamente. Esta pode ter sido uma das razões para não ter sido encontrada diferença também na TO. Contudo, os grupos BE $8(\mathrm{TO}=70 \%)$ e principalmente o $\mathrm{CE} 8(\mathrm{TO}=$ $50 \%$ ), tiveram desempenho abaixo dos $80 \%$ relatados na literatura (Meneghetti et al., 2009; Sales 
et al., 2012). O prolongamento da permanência da P4 para nove dias poderá aumentar a taxa de ovulação destes protocolos por permitir um maior tamanho do FD após sua retirada.

O tempo entre a retirada da $\mathrm{P} 4$ e a ovulação foi menor no grupo BE 8, além de ter tido uma variação menor do que no grupo Controle e CE 8. Vynckier et al. (1990) e Souza et al. (2005) verificaram que a aplicação de BE levou a um pico na concentração de E2 maior e mais precoce que o CE. Ainda, a concentração de E2 após a aplicação de CE levou um tempo maior entre sua elevação e redução para concentrações anteriores a aplicação, constatando uma meiavida maior que a do BE (Souza et al., 2005). Vynckier et al. (1990) relatam que devido ao CE ter baixa solubilidade em água, sua liberação é lenta e prolongada quando comparado ao BE. Em relação ao perfil circulatório do hormônio luteinizante (LH), assim como a concentração do E2, a aplicação do BE levou a um pico de maior magnitude, mais precoce, menor dispersão e de menor duração que o CE (Sales et al., 2012). Não houve diferença no TOV entre o grupo Controle e o CE. Souza et al. (2005) verificaram que o perfil circulatório do E2 foi similar entre os animais Controle ou tratados com CE. Neste caso, seria indiferente a aplicação do CE ou não (Controle), pois ambos não diferiram nos parâmetros reprodutivos, incluindo a sincronização do momento da ovulação.

Sales et al. (2012) trabalhando com fêmeas Nelore não observaram diferença na dispersão das ovulações entre o $\mathrm{CE}$ e o BE, o que foi verificado nas vacas Curraleiras Pé-Duro. Contudo, a administração do BE no referido experimento foi realizada 24 horas após a retirada da P4. A utilização do BE no dia da retirada da P4 no presente estudo foi realizada com o objetivo de diminuir o número de manejos no curral e o estresse dos animais devido a inexperiência das propriedades na utilização da IATF. Ross et al. (2004) trabalhando com vacas Angus não encontraram diferença na TO, TOV, diâmetro do FO, taxa de crescimento do FO, área do CL, concentração de P4 e taxa de prenhez entre a aplicação de BE junto com a retirada da P4 ou 24 horas após. Ayres et al. (2008) trabalhando com vacas Nelore encontraram maior tamanho do FD e intervalo para ovulação quando o BE foi aplicado 24 horas após a retirada da P4. Contudo, a taxa de prenhez foi similar quando a IA ocorreu 48 horas após a retirada da P4 independente de quando o BE foi aplicado.

$\mathrm{O}$ volume do CL e a concentração de P4 não diferiram entre os grupos provavelmente devido ao tamanho similar do FO. O maior tamanho do FO está relacionado ao maior tamanho do CL e concentração de P4 (Vasconcelos et al., 2001; Tortorella et al., 2013). 
Vacas com concentração menor que $1 \mathrm{ng} / \mathrm{ml}$ de P4 foram excluídas da análise, havendo duas possibilidades para terem sido encontradas estas concentrações. A primeira indica uma regressão prematura do CL, contudo esta situação é mais visualizada em animais em estresse nutricional e/ou anestro pós-parto (Williams et al., 1989; Tortorella et al., 2013). Adicionalmente, a administração de uma fonte de P4 ao protocolo de IATF tem como função impedir a ocorrência de ciclos curtos, ou seja, luteólise prematura (Yavas \& Walton, 2000). A segunda, mais provável, está relacionada a alguma alteração na amostra que possa ter interferido na correta dosagem. Isto porque nos dias 5 e 15 após ovulação os animais tinham concentração superior a $1 \mathrm{ng} / \mathrm{ml}$, enquanto que no dia 10 a concentração foi menor.

No Experimento 2, o BE foi escolhido como indutor da ovulação por ter levado a uma maior sincronia da mesma em relação ao CE. Dransfield et al. (1998) e Roelofs et al. (2006) obtiveram taxa de prenhez máxima quando a IA foi realizada entre 24 e 12 horas antes da ovulação. Desta forma, o indutor da ovulação, no caso o BE, que levou a um menor intervalo entre as mesmas, possibilitaria uma melhor adequação do horário ótimo para a IATF. Além disto, quanto maior o intervalo entre a primeira e a última ovulação (situação observada com o CE) maior é o desafio para o sêmen manter-se viável até esta última, principalmente quando o sêmen é de baixa qualidade.

O eCG não teve efeito em nenhum dos parâmetros avaliados, diferente de vários trabalhos que relatam seus efeitos benéficos no aumento do tamanho do FO, CL, concentração de P4 e taxa de prenhez (Sá Filho et al., 2010b; Sales et al., 2011b; Tortorella et al., 2013; NúnezOlivera et al., 2014). Nos bovinos o eCG atua tanto nos receptores de FSH como de LH (Murphy \& Martinuk, 1991). Desta forma estimula a produção de E2 e P4 pelo FD e CL, respectivamente (Baruselli et al., 2004). A maior produção de E2 por parte do FD parece estar ligada ao aumento da concentração de RNAm para a enzima P450-17a (Soumano et al., 1996, 1998). Já a maior produção de P4 pelo CL envolve o aumento no número e tamanho das células luteais, mitocôndrias e expressão da proteína regulatória esteroidogênica (STAR) no CL (Fátima et al., 2013; Rigoglio et al., 2013). A ação potencializada do eCG no FD e CL deve-se a sua longa meia-vida (aproximadamente três dias), conferida pelo alto teor de ácido siálico (Murphy \& Martinuk, 1991).

A boa CC das vacas e sua ciclicidade, provavelmente foram as causas para o eCG não ter estimulado o crescimento do FD e CL como esperado (Barreiros et al., 2014). Estudos 
relatam que sua ação é mais efetiva em animais com déficit na pulsatilidade de LH, por exemplo, durante o anestro pós-parto, puberdade ou em animais com baixa CC (Baruselli et al., 2004; Sá Filho et al., 2010b; Salles et al., 2011b; Núnez-Olivera et al., 2014). O eCG foi utilizado durante o período da seca, quando a qualidade e quantidade de forragem é inferior e os animais tendem a perder peso. Contudo, as vacas não sofreram quedas acentuadas em sua CC que levasse ao eCG ter efeito positivo. Serrano et al. (2004) e Bianchini et al. (2006) relatam que a morfologia (pequeno porte) do Curraleiro Pé-Duro é uma adaptação para regiões com déficit alimentar e hídrico, demonstrando a resistência a condições adversas.

Embora não tenha havido diferença significativa na concentração de P4 entre os grupos, houve aumento de aproximadamente $3 \mathrm{ng} / \mathrm{ml}$ no grupo eCG em relação ao Controle. A maior concentração de P4 após concepção está relacionada ao maior desenvolvimento embrionário (Carter et al., 2008), secreção de interferon- $\tau$ (IFN- $\tau$; Mann et al., 2006) e taxa de prenhez (Tortorella et al., 2013).

O conhecimento da dinâmica folicular e luteal em um protocolo de IATF são fundamentais para utilização desses protocolos com resultados satisfatórios. O protocolo a base de P4 e BE teve boa eficiência em sincronizar o crescimento do FD. O BE teve melhor desempenho em função da maior sincronia entre as ovulações, facilitando a escolha do momento da IA e diminuindo o desafio para o sêmen. Já o eCG não teve efeito no desenvolvimento folicular e luteal, muito provavelmente pela resistência da raça localmente adaptada ao estresse climático e nutricional. A menor necessidade da utilização do eCG na raça pode ser considerada uma vantagem econômica devido ao menor custo do protocolo hormonal e consequentemente menor custo para produzir um bezerro. Outros experimentos devem avaliar a aplicação do BE um dia após a retirada da P4 e a maior permanência desta. 


\section{AGRADECIMENTOS}

Os autores agradecem a CAPES pela bolsa estudantil, ao CNPq e a FAP-DF pelo suporte financeiro e a Rede Centro-Oeste de Pós-Graduação, Pesquisa e Inovação. 


\section{REFERÊNCIAS BIBLIOGRÁFICAS}

ANUÁRIO DA PECUÁRIA BRASILEIRA / CIÊNCIAS DA TERRA / CIÊNCIAS AGRÁRIAS, PECUÁRIA, PESCA E PSCICULTURA. ANUALPEC. 20.ed. Brasil: FNP, 2013.

AYRES, H.; MARTINS, C.M.; FERREIRA, R.M. et al. Effect of timing of estradiol benzoate administration upon synchronization of ovulation in suckling Nelore cows (Bos indicus) treated with a progesterone-releasing intravaginal device. Animal Reproduction of Science, v. 109, p. 77-87, 2008.

BARREIROS, T.R.R.; BLASCHI, W.; SANTOS, G.M.G. et al. Dynamics of follicular growth and progesterone concentrations in cyclic and anestrous suckling Nelore cows (Bos indicus) treated with progesterone, equine chorionic gonadotropin, or temporary calf removal. Theriogenology, v. 81, p. 651-656, 2014.

BARUSELLI, P.S.; REIS, E.L.; MARQUES, M.O. et al. The use of hormonal treatments to improve reproductive performance of anestrous beef cattle in tropical climates. Animal Reproduction of Science, v, 82-83, p. 479-486, 2004.

BIANCHINI, E.; CCONCEPTA, M.; LUCCI, C.M. et al. Características corporais associadas com a adaptação ao calor em bovinos naturalizados brasileiros. Brazilian Agriculture Research, v. 41, p. 1443-1448, 2006.

CARTER, F.; FORDE, N.; DUFFY, P. et al. Effect of increasing progesterone concentration from Day 3 of pregnancy on subsequent embryo survival and development in beef heifers. Reproduction Fertility and Development, v. 20, p. 368-375, 2008.

CARVALHO, J.B.P.; CARVALHO, N.A.T.; REIS, E.L. et al. Effect of early luteolysis in progesterone-based timed AI protocols in Bos indicus, Bos indicus x Bos taurus, and Bos taurus heifers. Theriogenology, v. 69, p. 167-175, 2008.

COLAZO, M.G.; KASTELIC, J.P.; MAPLETOF, R.J. Effects of estradiol cypionate (CE) on ovarian follicular dynamics, synchrony of ovulation, and fertility in CIDR-based, fixed-time AI programs in beef heifers. Theriogenology, v. 60, p. 855-865, 2003. 
COLAZO, M.G.; KASTELIC, J.P.; MARTINEZ, M.F. et al. Fertility following fixed-time AI in CIDR-treated beef heifers given GnRH or estradiol cypionate and fed diets supplemented with flax seed or sunflower seed. Theriogenology, v. 61, p. 1115-1124, 2004.

EGITO, A.A.; Mariante, A.S.; Albuquerque, M.S.M. Programa brasileiro de conservação e recursos genéticos. Archives of Zootechnology, v. 51, p. 39-52, 2002.

FÁTIMA, L.A.; BARUSELLI, P.S.; GIMENES, L.U. et al. Global gene expression in the bovine corpusluteum is altered after stimulatory and superovulatory treatments. Reproduction Fertility and Development, v. 25 (7), p. 998-1011, 2012.

FIORAVANTI, M.C.S.; JULIANO, R.S.; COSTA, G.L. et al. Conservación del bovino Curraleiro: cuantificación del censo y caracterización de los criadores. Animal Genetic Resources, v. 48, p. 109-116, 2011.

GINTHER, O.J.; KOT, K.; KULLICK, L.J. et al. Emergence and deviation of follicles during the development of follicular waves in cattle. Theriogenology, v. 48, p. 75-87, 1997.

MANN, G.E.; FRAY, M.D.; LAMMING, G.E. Effects of time of progesterone supplementation on embryo development and interferon-tau production in the cow. Veterinary Journal, v. 171, p. 500-503, 2006.

MARIANTE, A.S.; EGITO, A.A. Animal Genetic resources in Brazil: result of five centuries of natural selection. Theriogenology, v. 57, p. 223-235, 2002.

MARTINEZ, M.F.; KASTELIC, J.P.; BÓ, G.A. et al. Effects of oestradiol and some of its esters on gonadotrophin release and ovarian follicular dynamics in CIDR-treated beef cattle. Animal Reproduction Science, v. 86, p. 37-52, 2005.

MENEGHETTI, M.; SA FILHO, O.G.; PERES, R.F.G. et al. Fixed-time artificial insemination with estradiol and progesterone for Bos indicus cows I: Basis for development of protocols. Theriogenology, v. 72, p. 179-189, 2009.

MURPHY, B.D.; MARTINUK, S.D. Equine chorionic gonadotropin. Endocrine Reviews, v. 12, p. 27-44, 1991.

NÚÑEZ-OLIVERA, R.; DE CASTRO, T.; GARCÍA-PINTOS, C. et al. Ovulatory response and luteal function after eCGadministration at the end of a progesterone and estradiol based treatment in postpartum anestrous beef cattle. Animal Reproduction Science, v. 146, p. 111-116, 2014.

PERRY, G.A.; SMITH, M.F.; ROBERTS, A.J. et al. Relationship between size of the ovulatory follicle and pregnancy success in beef heifers. Journal of Animal Science, v. 85, p. 684-689, 2007.

PFEIFER, L.F.M.; LEONARDI, C.E.P.; CASTRO, N.A. et al. The use of PGF2a as ovulatory stimulus for timed artificial insemination in cattle. Theriogenology, v. 81, p. 689-695, 2014. 
ROSS, P.J.; ALLER, J.F.; CALLEJAS, S.S. et al. Estradiol benzoate given 0 or $24 \mathrm{~h}$ after the end of a progestagen treatment in postpartum suckled beef cows. Theriogenology, v. 62, p. 265-273, 2004.

SÁ FILHO, M.F.; PENTEADO, L.; REIS, E.L. et al. Timed artificial insemination early in the breeding season improves the reproductive performance of suckled beef cows. Theriogenology, v. 79, p. 625-632, 2013.

SA FILHO, M.F.; CRESPILHO, A.M.; SANTOS, J.E. et al. Ovarian follicle diameter at timed insemination and estrous response influence likelihood of ovulation and pregnancy after estrous synchronization with progesterone or progestin-based protocols in suckled Bos indicus cows. Animal Reproduction Science, v. 120, p. 23-30, 2010a.

SÁ FILHO, M.F.; TORRES-JÚNIOR, J.R.S.; PENTEADO, L. et al. Equine chorionic gonadotropin improves the efficacy of a progestin-based fixed-time artificial insemination protocol in Nelore (Bos indicus) heifers. Animal Reproduction Science, v. 118, p. 182-187, $2010 b$.

SALES, J.N.S.; CREPALDI, G.A.; GIROTTO, R.W. et al. Fixed-time AI protocols replacing eCG with a single dose of FSH were less effective in stimulating follicular growth, ovulation, and fertility in suckled-anestrus Nelore beef cows. Animal Reproduction Science, v. 124, p. 12-18, $2011 b$.

SALES, J.N.S.; CARVALHO, J.B.P.; CREPALDI, G.A. et al. Effects of two estradiol esters (benzoate and cypionate) on the induction of synchronized ovulations in Bos indicus cows submitted to a timed artificial insemination protocol. Theriogenology, v. 78, p. 510-516, 2012.

SARTORI, R.; FRICKE, P.M.; FERREIRA, J.C.P. et al. Follicular Deviation and Acquisition of Ovulatory Capacity in Bovine Follicles. Biology of Reproduction, v. 65, p. 1403-1409, 2001.

SERRANO, G.M.; EGITO, A.A.; MCMANUS, C. et al. Genetic diversity and population structure of Brazilian native bovine breeds. Brazilian Agriculture Research, v. 39, p. 543-549, 2004.

SOUMANO, K.; LUSSIER, J.G.; PRICE, C.A. Levels of messenger RNA encoding ovarian receptors for FSH and $\mathrm{LH}$ in cattle during superovulation with equine chorionic gonadotrophin versus FSH. Journal of Endocrinology, v. 156, p. 373-378, 1998.

SOUMANO, K.; SILVERSIDES, D.W.; DOIZE, F. et al. Follicular 3 betahydroxysteroid dehydrogenase and cytochromes P450 17 alphahydroxylase and aromatase messenger ribonucleic acids in cattle undergoing superovulation. Biology of Reproduction, v. 55, p. 1419-1426, 1996.

SOUZA, A.H.; CUNHA, A.P.; CARAVIELLO, D.Z. et al. Profiles of circulating estradiol-17 $\beta$ after different estrogen treatments in lactating dairy cows. Animal Reproduction, v. 2, p. 224232, 2005. 
TORTORELLA, R.D.; FERREIRA, R.; DOS SANTOS, J.T. et al. The effect of equine chorionic gonadotropin on follicular size, luteal volume, circulating progesterone concentrations, and pregnancy rates in anestrous beef cows treated with a novel fixed-time artificial insemination protocol. Theriogenology, v. 79, p. 1204-1209, 2013.

VASCONCELOS, J.L.; SARTORI, R.; OLIVEIRA, H.N. et al. Reduction in size of the ovulatory follicle reduces subsequent luteal size and pregnancy rate. Theriogenology, v. 56, p. 307-314, 2001.

VYNCKIER, L.; DEBACKERE, M.; DEKRUIF, A. et al. Plasma estradiol-17 $\beta$ concentrations in the cow during induced estrus and after injection of estradiol- $17 \beta$ benzoate and estradiol-17 $\beta$ cyprionate-a preliminary study. Journal of Veterinary Pharmacology and Therapeutics, v. 13, p. 36-42, 1990.

WILLIAMS, G.L. Modulation of luteal activity in postpartum beef cows through changes in dietary lipid. Journal of Animal Science, v. 67, p. 785-793, 1989.

YAVAS, Y.; WALTON, J.S. Induction of ovulation in postpartum suckled beef cows: a review. Theriogenology, v. 54, p. 1-23, 2000. 


\section{CAPÍTULO 5}

\section{CONSIDERAÇÕES FINAIS}

Os resultados encontrados neste estudo demonstram que apesar da origem europeia, o rebanho atual da raça apresenta muitas características comuns aos Bos indicus. Estas características podem ter sido inseridas pelos cruzamentos desordenados, principalmente com o Nelore, sendo esta provavelmente, uma das causas da diminuição da população na raça.

$\mathrm{Na}$ maior parte dos itens avaliados não houve diferença nos parâmetros da fisiologia reprodutiva estudados, entre vacas cíclicas não lactantes e novilhas, com exceção do intervalo entre a ovulação e a emergência folicular e a ovulação e a divergência folicular, sendo ambos os intervalos menores nas vacas. Este achado será de grande importância para a correta manipulação hormonal dependendo da categoria animal, principalmente em protocolos de MOTE. O elevado número de folículos na emergência folicular também indica o potencial da raça para ser explorado na PIVE. Assim como, a inexistência de diferença na duração do ciclo estral e da primeira onda, entre animais com duas e três ondas, facilita a manipulação hormonal para a IATF.

Nos protocolos de IATF, o BE apresentou desempenho superior ao CE. Contudo, o eCG não foi capaz de estimular o crescimento folicular e luteal. Este achado provavelmente se deve a boa condição corporal dos animais durante o experimento, o que só demonstra a adaptação da raça a condições como clima seco e quente. 
O Curraleiro Pé-Duro possui grande potencial para ser explorado como um nicho de mercado alternativo, sendo apenas necessário que pesquisas sejam desenvolvidas para que as decisões sejam tomadas de maneira consciente e embasadas, propiciando o crescimento da raça. Neste sentido, a Rede Pró-Centro-Oeste vem contribuindo de maneira ímpar para o maior conhecimento da raça, através de pesquisas nas áreas da caracterização reprodutiva, fenotípica e genotípa, filogenética, avaliação da qualidade do leite e potencial de exploração. Além de estimular a formação de recursos humanos que darão sequencia no conceito de utilizar os recursos naturais de maneira sustentável e desta forma, preservar a raça Curraleiro Pé-Duro. 